\title{
Angiotensin II and vascular growth in vivo : the role of the alpha1-adrenoreceptor
}

Citation for published version (APA):

van Kleef, E. M. (1993). Angiotensin II and vascular growth in vivo : the role of the alpha1-adrenoreceptor. [Doctoral Thesis, Maastricht University]. Datawyse / Universitaire Pers Maastricht. https://doi.org/10.26481/dis.19931210ek

Document status and date:

Published: 01/01/1993

DOI:

10.26481/dis.19931210ek

Document Version:

Publisher's PDF, also known as Version of record

\section{Please check the document version of this publication:}

- A submitted manuscript is the version of the article upon submission and before peer-review. There can be important differences between the submitted version and the official published version of record.

People interested in the research are advised to contact the author for the final version of the publication, or visit the DOI to the publisher's website.

- The final author version and the galley proof are versions of the publication after peer review.

- The final published version features the final layout of the paper including the volume, issue and page numbers.

Link to publication

\footnotetext{
General rights rights.

- You may freely distribute the URL identifying the publication in the public portal. please follow below link for the End User Agreement:

www.umlib.nl/taverne-license

Take down policy

If you believe that this document breaches copyright please contact us at:

repository@maastrichtuniversity.nl

providing details and we will investigate your claim.
}

Copyright and moral rights for the publications made accessible in the public portal are retained by the authors and/or other copyright owners and it is a condition of accessing publications that users recognise and abide by the legal requirements associated with these

- Users may download and print one copy of any publication from the public portal for the purpose of private study or research.

- You may not further distribute the material or use it for any profit-making activity or commercial gain

If the publication is distributed under the terms of Article $25 \mathrm{fa}$ of the Dutch Copyright Act, indicated by the "Taverne" license above, 


\section{ANGIOTENSIN II AND VASCULAR GROWTH IN VIVO}

the role of the $\alpha_{1}$-adrenoreceptor 
Cover: Photomicrograph representing a part of a cross-section of a balloon injured rat carotid artery hybridized with a $\left[{ }^{35} \mathrm{~S}\right]$ mabeled collagen type I probe. The spots represent the expression of the collagen type I mRNA. The expression is most abundant in the neointima (the newly formed vessel layer after balloon injury, at the lower part of the photograph) and the expression is least abundant in the media (the vessel layer with laminae, above the middle of the photograph).

\section{CIP-DATA KONINKLIJKE BIBLIOTHEEK, DEN HAAG}

Kleef, Eleonora Maria wan

Angiotensin II and wascular growth in vivo: the role of the $\alpha_{1}$-adrenoreceptor/ Eleonora Maria van Kleef. Maastricht: Universitaine Pers Maastricht. -111.

Thesis Mastricht. - With ref.

ISBN $90-5278-109-5$

Subject headings: angiotensin $11 /$ restenosis / smooth muscle cell. 


\title{
ANGIOTENSIN II AND VASCULAR GROWTH IN VIVO
}

the role of the $\alpha_{1}$-adrenoreceptor

\author{
PROEFSCHRIFT
}

ter verkrijging van de graad van doctor

aan de Rijksuniversiteit Limburg te Maastricht,

op gezag van de Rector Magnificus, Prof. dr. H. Philipsen,

volgens het besluit van het College van Dekanen,

in het openbaar te verdedigen op

vrijdag 10 december 1993 om 14.00 uur

door

Eleonora Maria van Kleef 


\section{Promotor}

Prof. dr. I.W. Arends

\section{Co-promotor}

Dr. M.J.A.P. Daemen

\section{Beoordelingscommissie}

Prof. dr. P.W. de Leeuw, voorzitter

Dr. F.W.H.M. Bär

Dr. J.G.R. De Mey

Prof. dr. S.M. Schwartz, University of Washington, Seattle, USA

Prof. dr. P.D. Verdouw, Erasmus Universiteit Rotterdam

Financial support by the Netherlands Heart Foundation for the publication of this thesis is gratefully acknowledged.

For financial support for the publication of this thesis we also thank:

- Pfizer B.V., the Netherlands.

- Leica B.V., the Netherlands

- Stichting Klinische Pathologie Zuid-Limburg 


\section{CONTENTS}

1. Introduction 1

1.1 General introduction 2

1.2 Balloon injury model 2

1.2.1 Kinetics of the response to injury 3

1.2.2 Growth regulation of the vascular response

1.3 Role of angiotensin II in vascullar remodeling 7

1.3.1 The remin-angiotensin system 7

$\begin{array}{ll}\text { 1.3.2 Effects of angiotensin II } & 10\end{array}$

1.3.3 Regulation of angiotensin II induced vascular growth effects in vivo and the role of the $\alpha_{1}$-adrenoreceptor 13

$\begin{array}{lll}1.4 \text { Hypothesis } & 15\end{array}$

$\begin{array}{ll}\text { 1.5 Aim of this study } & 16\end{array}$

$\begin{array}{ll}\text { References } & 18\end{array}$

2. Materials and methods 31

2.1 Animals $\quad 32$

2.2 Surgery 32

2.2.1 Aortic and carotid endothelial denudation 32

2.2.2 Implantation of minipumps $\quad 32$

2.3 Blood pressure measurements 33

2.4 Tissue processing 33

2.5 Histology 34

2.5.1 Immunohistochemistry 34

2.5.2 Morphometry 35

2.5.3 In situ hybridization $\quad 36$

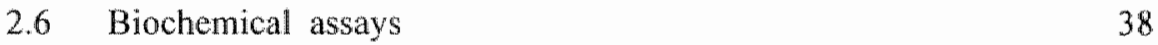

2.6.1 Plasma catecholamines $\quad 38$

2.6.2 Tissue elastin and collagen 39

2.7 Statistics $\quad 40$

References 41

3. Comparison of the determination of DNA synthesis by ${ }^{3} \mathrm{H}$ thymidine and 5-bromo-2'-deoxyuridine in the balloon injured rat thoracic aorta.

4. Reduction of the angiotensin II induced vascular smooth muscle cell DNA synthesis in the rat thoracic aorta by $\alpha_{\mu}$-adrenoreceptor blockade. 

5. Heterogeneity of the angiotensin II. induced rat vascular smooth muscle cell DNA synthesis: effects of $\alpha_{1}$-adrenoreceptor blockade.

6. Heterogeneous effects of $\alpha_{1}$-adrenoceptor blockade with doxazosin on the angiotensin II induced smooth muscle cell DNA synthesis in the balloon injured rat carotid artery.

7. Effects of a short term infusion of phenylephrine or angiotensin. II on smooth muscle cell DNA synthesis and medial cross-sectional area in young rats.

8. Effects of a continuous phenylephrine infusion on vascular smooth muscle cell DNA synthesis in the balloon injured rat carotid artery - role of nitric oxide.

9. Effects of angiotensin 11 on elastin and collagen mRNA and protein contents in the balloon injured rat carotid artery.

10. General discussion

10.1 General

10.2 Restimulation of medial and neointimal SMC. A model for studying the pathogenesis of restenosis.

10.3 Angiotensin II and the $\alpha_{1}$-adrenoreceptor.

10.4 Other possible mechanisms involved in the angiotensin II induced smooth muscle cell DNA synthesis.

10.5 Critical notes

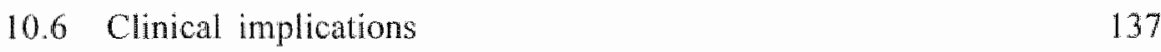

$\begin{array}{ll}\text { References } & 138\end{array}$

Summary

142

Samenvatting

Curriculum vitae

List of publications

Dankwoord 


\section{LIST OF ABBREVIATIONS}

$\begin{array}{ll}\text { AnglI } & \text { angiotensin II } \\ \text { BrdUrd } & \text { 5-bromo-2'-deoxyuridine } \\ \text { CNS } & \text { central nervous system } \\ \text { CSA } & \text { cross-sectional area } \\ \text { DMSO } & \text { dimethylsulfoxide } \\ \text { ECM } & \text { extracellular matrix } \\ \text { ISH } & \text { in situ hybridization } \\ \text { NE } & \text { norepinephrine } \\ \text { NO } & \text { nitric oxide } \\ \text { ras } & \text { renin-angiotensin system } \\ \text { SBP } & \text { systolic blood pressure } \\ \text { SMC } & \text { smooth muscle cell } \\ \text { S.c. } & \text { subcutaneously } \\ {\left[{ }^{3} \mathrm{H}\right] \text { TdR }} & \text { tritiated thymidine }\end{array}$


CHAPTER 1

INTRODUCTION 


\subsection{GENERAL INTRODUCTION}

Percutaneous transluminal coronary angioplasty (PTCA) was introduced in 1977 (1) and was initially used to treat patients with a discrete, proximal, noncalcified non-occlusive lesion in a single coronary artery. Nowadays, PTCA has much broader applications and is applied to patients with multivessel disease, multiple stenoses in the same vessel, occlusion of grafts and recent thrombotic coronary acclusions $(2,3)$.

Although the initial outcome of coronary angioplasty procedures thas improved (with success rates of 90 to $95 \%$ ), the long-term efficacy of the procedure is seriously limited by restenosis over the first 6 to 8 months. Despite the introduction of alternative atherectomy devices, the incidence of restenosis has remained unchanged and is approximately $30-40 \%(4-8)$.

Morphological studies show that the predominant cell type in restenotic lesions is the smooth muscle cell (SMC) $(9,10)$ and SMC proliferation has been seen as a key event in restenosis. However, recent quantitative evidence of SMC proliferation in human lesions has yielded contradictory results (11-13). Different experimental animal models, such as balloon injury and surgical placement of synthetic or venous grafts are used, to simulate PTCA procedures and study the regulation of $S M C$ proliferation. In one of these models, the balloon injury model of the carotid artery of the rat, the kinetics of SMC proliferation have been extensively studied and research is now focusing on the molecular mechanisms involved in $\mathrm{SMC}$ growth regulation.

In this thesis the role of angiotensin II on vascular smooth muscle cell growth (DNA synthesis and extracellular matrix (ECM) production) is studied in both balloon injured and non-injured arteries of the rat. An interaction between angiotensin $\llbracket I$ and the $\alpha_{1}$-adrenoreceptor was identified and possible mechanisms of this interaction were investigated.

\subsection{BALLOON INJURY MODEL}

This classic model of vessel wall injury was first described by Baumgartner in 1963 in the rabbit abdominal aorta (14). A modification of the original model as described by Clowes et al. (15) is now used to study the cellular response after arterial injury.

The response of the vessel wall to injury can be divided in several stages, so-called "waves": The first wave is characterized by SMC proliferation in the media and is quantified by counting the number of DNA synthesizing SMC in the first three days after balloon injury. SMC DNA synthesis is measured as incorporation of tritiated thymidine $\left.\left({ }^{3} \mathrm{H}\right] \mathrm{T} \mathrm{dR}\right)$. The second "wave" includes the migration of SMC 
from the media towards the intima. Migration is measured by determination of the number of intimal SMC at day 4 after injury (16). The third "wave" is characterized by intimal SMC proliferation as well as synthesis and deposition of extracellular matrix. The third "wave" responses are measured by the curnulative labeling indices in the neointima, and by measuring cross-sectional areas of media and neointima $(15,17,18)$. The newly formed neointima remains hyperresponsive to growth modulators. 2 Weeks after balloon injury, the already formed neointima can be restimulated to replicate $(19,20)$, this fourth "wave" is called "restimulation".

\subsubsection{Kinetics of the response to injury}

Medial SMC DNA synthesis, as measured by incorporation of tritiated thymidine, starts as soon as 24 hrs after injury and reaches its maximum 48 hrs after injury (15). Medial SMC migrate between day 3 and $4(15,18,21)$. Only $50 \%$ of all migrating medial SMC replicate to form a neointima (18). Proliferation of neointimal SMC is maximal at day 4-7. At two weeks the greatest number of SMC is present in the intima, representing $60-80 \%$ of the cells in the injured wall (15). The total number of SMC remains relatively constant up to one year, despite a slightly increased replication rate that is countered by an increased cell loss (21). The neointimal thickening continues for up to 12 weeks, due to an increased SMC cell volume as well as synthesis and accumulation of extracellular matrix (ECM) containing collagen, elastin and proteoglycans $(15,22-24)$. The thickened vessel remains in a stable state for at least one year (21). Endothelial cell regrowth in the balloon injured carotid artery initially progresses at about $2 \mathrm{~mm}$ per week, but gradually slows down until it ceases between 6 (25) and 10 weeks (26). The central region of the injured carotid artery thus fails to be recovered with endothelium (25).

\subsubsection{Growth regulation of the vascular response to injury}

Until recently, SMC proliferation and migration after injury were considered to be largely due to the release of growth factors from platelets adhering to the denuded vessel wall (27). However, studies with anti-platelet antisera in rats (28) showed that platelets do not play a major role in the stimulation of SMC replication alter injury. It was also thought that endothelial cell damage might cause intimal proliferation, through the loss of endothelium-derived growth inhibitors (e.g. heparin sulfate) (29), and the induction of growth factors produced by the media. However, endothelial cell injury alone does not cause intimal proliferation (30), suggesting either that medial damage is a prerequisite for SMC proliferation, or that medial damage enhances the rate at which SMC proliferation lakes place. The 
latter suggestion is favored by the observation that minimal medial injury (by a filament loop) prevents early (30), but not late neointimal thickening (26).

A diversity of polypeptide growth factors have been demonstrated to be induced after balloon injury. The factors which are found to play a critical role in the sequence of events after injury are summarized in table 1.1. Evidence for a role of these factors is obtained from the attempt to stimulate or inhibit their action.

Table 1.1 Mediators involved in the response to injury events

\begin{tabular}{|c|c|c|c|c|}
\hline & & & widence & \\
\hline & mediators & agonist & antagonist & antibody \\
\hline \multirow{2}{*}{$\begin{array}{l}\text { 1. medial } \mathrm{SMC} \\
\text { replication }\end{array}$} & PDGF & - & NA & - \\
\hline & $b \mathbb{F G F}$ & + & NA & + \\
\hline \multirow[t]{3}{*}{ 2. SMC migration } & PDGF & + & NA & + \\
\hline & $\mathrm{bFGF}$ & + & NA & + \\
\hline & AngIII & ND & + & NA \\
\hline \multirow{4}{*}{$\begin{array}{l}\text { 3. intimal SMC } \\
\text { replication }\end{array}$} & bFGF & + & NA & - \\
\hline & Angll & + & + & NA \\
\hline & bradykinin & $\mathbb{1}$ & + & NA \\
\hline & $\mathrm{TGF}-\mathrm{B}_{1}$ & + & $\mathrm{NA}$ & NA \\
\hline
\end{tabular}

$+=$ evidence for a role of a specific mediator; $-=$ no support for a role of a specific mediator Abloreviations: $N A=$ not avalable; $N D=$ not determined: $P D G F=$ platelet derived growth factor; bFGF= basic libroblast growth factor; $T G F-B_{1}=$ transforming growth factor $-S_{1}$.

\section{Platelet Derived Growth Factor}

Infusion of recombinant platelet derived growth factor-BB ( $\mathrm{PPDGF}-\mathrm{BB}$ ) into rats directly after balloon or filament injury does not result in a higher medial replication rate (31). rPDGF infusion over 7 days after filament loop injury results in a 15 fold thicker intima than in non PDGF treated balloon injured rats, suggesting that PDGF affects migration (31). Further support for a role of PDGF on migration comes from the observation that balloon injured nude rats treated with a polyclonal anti-PDGF antibody do not exhibit a lower medial, nor intimal replication rate in comparison with non anti-PDGF antibody treated animals. However, the neointimal 
area of anti-PDGF antibody treated rats shows a $41 \%$ reduction in comparison with the neointimal area of the controls (32).

\section{Basic Fibroblast Growth Factor}

Intravenous infusion of basic fibroblast growth factor (bFGF) immediately after injury results in a 5-fold increase of $\mathrm{SMC}$ replication in the media at 48 hours after injury (33), and a 2 -fold increase in the neointimal area after 14 days. bFGF also stimulates increased endothelial regeneration (34). The stimulatory effects on SMC replication are only found in the absence of endothelium (35). It has been suggested that the endothelium serves as a functional barrier for the mitogenic effects of bFGF, because the infusion of bFGF at the adventitial site does onlly stimulate replication in the left carotid artery devoid of endothelium and not in the intact right carotid artery with endothelium (35). At 14 days after injury a larger neointima is found in bFGF treated rats in comparison with non-bFGF-treated controls, suggesting that bFGF is mitogenic for SMC in vivo (35).

Studies with an anti-bFGF antiserum (administered directly prior to and repeatedly following balloon injury) showed that medial SMC proliferation can be blocked almost completely (36). However, when the same antiserum is infused 4 and 5 days after balloon injury, it was not able to decrease neointimal SMC proliferation. This observation, together with the finding that bFGF mRNA and protein synthesis in the arterial wall decreases after injury in the media and neointima of the injured carotid artery, suggests that bFGF does not play a key role in intimal proliferation (37).

\section{Transforming Growth Factor- $\beta$,}

The $\mathrm{TGF}^{\mathrm{N}}-\mathrm{B}_{1}$ mRNA content is increased in the balloon injured rat carotid artery, as soon as 6 hrs after injury and remains elevated for at least two weeks (20). TGF-B, protein is found in almost all neointimal $\mathrm{SMC}$ and in about $50 \%$ of the underlying medial SMC two weeks after injury (20) and this TGF-B, protein expression is still found 10 wks after injury (38). Infusion of recombinant TGF $B_{1}$, two weeks after injury results in an increased neointimal SMC proliferation, without an effect on the media (20). Thus, TGF-\$, plays a critical role in both the third (intimal SMC replication) and possibly the fourth wave (restimulation) after balloon injury.

\section{Other possible mediators}

\section{Heparin}

Heparim inhibits intimal hyperplasia by blocking SMC proliferation and migration, and by modulation of the extracellular matrix $(22,29,39)$. Administration of heparin together with the angiotensin I converting enzyme (ACE) inhibitor cilazapril adds to the inhibition of neointima formation (40). The mechanism of these 
growth reducing effects of heparin on SMC is however unclear, but several hypotheses may be considered. Firstly, administration of heparin to SMC in vitro has been shown to inhibit the serum stimulated increase in c-myb transcription factor expression (41), and prevents SMC to enter into $S$ phase. The inhibition of c-myb expression might also explain the in vivo effects of heparin, since local administration of anti-sense c-myb oligonucleotides to the injured vessel wall almost completely prevents neointima formation (42). A second mechanism involves the inhibition of $\mathrm{Ca}^{2+}$ mobilization through an effect on the inositol 1,4,5triphosphate receptor $(43,44)$, A third mechanism is related to the ability of heparin to displace bFGF from its matrix binding sites, resulting in the partitioning of bFGF into the circulation (45).

\section{$\mathrm{Ca}^{24}$ channel blockers}

Administration of $\mathrm{Ca}^{2+}$ channel blockers has shown that these drugs can inhibit SMC proliferation. But as for heparin, the mechanism of action and selectivity are as yet unclear. The $\mathrm{Ca}^{2-1}$ blocker nifedipine can only inhibit medial SMC proliferation when administered between 8 and 30 hrs after injury (46). Another $\mathrm{Ca}^{2+}$ blocker, PN 200-110, caused a 44\% suppression of neointima formation (47). $\mathrm{Ca}^{2+}$ blockers probably interfere with factors involved in growth regulation, like PDGF (48), but the exact mechanism has to be elucidated.

\section{Nitric oxide}

Under normal conditions endothelial cells produce $\mathrm{NO}$, which relaxes vascular smooth muscle (49-51) and inhibits platelet adhesion and aggregation (52). After balloon injury of the carotid artery SMC are also found to produce NO (53), which is potentiated by the administration of interleukin- $B$ (II- $B$ ). The activation of inducible NO symthase is suggested to be due to cytokines released by blood cells adhering to the denuded segment.

The lunctional role of NO in the response to injury is only speculative. It may play a role in inhibiting platelet adhesion and aggregation with subsequent release of growth factors. Furthermore, NO may reduce SMC proliferation after injury, since NO is known to inhibit SMC DNA synthesis in cell culture (54-56), but not in arterial organ culture $(57,58)$.

Flow

Also, stuctural responses of the vessel wall to changes in flow (as a consequence of the injury) have to be considered. A low flow in the carotid artery of the young rabbit results in a decrease in lumen diameter (59). This flow effect is endothelium-dependent, since no difference in luminal diameter was found in the denuded rabbit carotid artery 2 weeks after balloon injury (59). However, recent evidence suggests that the deendothelized area may also respond to changes in 
blood flow $(60,61)$. Induction of high flow (by ligation of the non-injured right carotid artery) resulted in a smaller intimal area and an increased lumen diameter at 2 and 4 weeks after balloon denudation of the left carotid artery in comparison with low flow induced by ligation of the left internal carotid artery (61).

\subsection{ROLE OF ANGIOTENSIN II IN VASCULAR REMODELING}

\subsubsection{The renin-angiotensin system}

The renin-angiotensin system (RAS) was originally found to be an endocrine system that regulates blood pressure and volume homeostasis. The classical biochemistry of the system is as follows: the enzyme renin, secreted into the circulation by the kidney, cleaves angiotensinogen secreted by the liver, to produce the biologically inactive decapeptide angiotensin I (AngL). AngI is then converted into the active octapeptide angiotensin II (AngII) by angiotensin converting enzyme (figure 1.1). Degradation of angiotensin II results in two heptapeptides: angiotensin III and angiotensin(1-7) (62). Both peptides stimulate prostaglandin formation, whereas in addition angiotensin III stimulates aldosterone secretion and angiotensin (1-7) increases vasopressin release (62).

Figure 1.1 The classical biochemistry of the renin-angiotensin system.

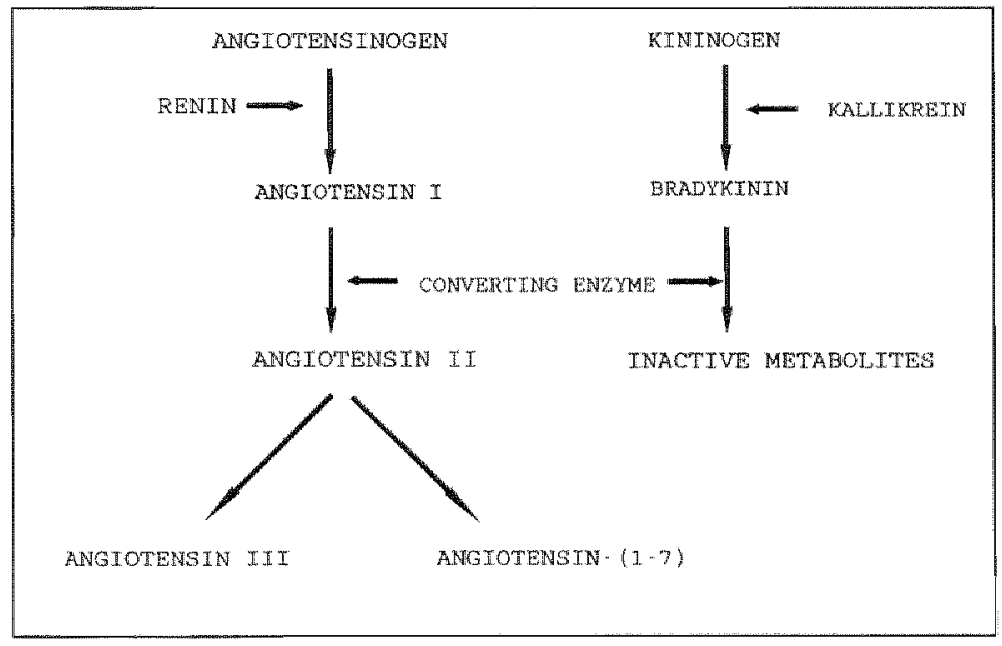

More recently, it has been suggested that endogenous renin-angiotensin systems exist in many tissues and that these local systems exert autocrine and paracrine influences on tissue functions. Originally, the existence of a local RAS has been deduced from biochemical, immunohistochemical and pharmacological studies that 
showed the localization of the different components of the RAS in multiple tissues, including the heart, the vascular wall, the kidney, the adrenal gland and the brain (63-69). The recent finding of mRNA expression of angiotensinogen, renin and ACE in tissues, including the vascular wall has given supplementary evidence for the existence and regulation of a local RAS (table 1.2).

Angiotensin converting enzyme (ACE) is also known to cleave other peptides than angiotensin I such is bradykinin, substance $P$, enkephalins, neurotensin and luteinizing hormone-releasing hormone $(70,71)$. Besides, alternative pathways to generate angiotensin II have been discovered. Other angiotensin II generating enzymes have been identified, which are important for the conversion of angiotensin I into angiotensin $\Pi$, such as chymostatin-sensitive angiotensin II generating enzyme (CAGE), trypsin, cathepsin G, kallikrein and tonin (72-75).

Table 1.2 Local expression of genes of the renin-angiotensin system.

\begin{tabular}{llll} 
& species & tissue/cell type & reference \\
\hline Angiotensinogen & rat & $\begin{array}{l}\text { aorta: adwentitia and surtoun- } \\
\text { ding fatty tissue }\end{array}$ & 78,79 \\
& rat & $\begin{array}{l}\text { aorta and carotid artery: } \\
\text { medial and neointimal SMC }\end{array}$ & 80,81 \\
Renin & rat & aorta & 88,89 \\
ACE & human & endothelium & 94 \\
& rat & aorta & 98 \\
AT receptor & rat & aorta & 103 \\
\hline
\end{tabular}

RAS componems in the vascular wall

Angiotensinogen production has been detected in rat aortic smooth muscle cells in culture (76) and also in vivo, small quantities were demonstrated in the extracellular fluid and blood (77). Angiotensinogen mRNA has been demonstrated in the adventitia and surrounding brown adipose tissue $(78,79)$ and in the medial and neointimal smooth muscle cells $(80,81)$.

In culture, canine aortic SMC (82), rat mesenteric SMC (83) and bovine aortic endothelial cells (84) have been shown to produce renin. In vivo, renin-like activity has been shown in various rat arteries (85) and also in rat veins (86). In large- and medium sized arteries immunoreactive renin is primarily present in the endothelium. and outer two thirds of the media, as well as in the adventitia (87). In small arteries and arterioles renin is found throughout the entire blood vessel (87). Small 
quantities of vascular remin mRNA have been demonstrated in the rat aorta $(88$, 89).

Angiotensin converting enzyme is present primarily in the endothelium $(90,91)$, but also in vascular smooth muscle cells $(92,93)$ and in the adventitia (75), whereas angiotensin converting enzyme mRNA production has been demonstrated in endothelium, but not in the media or adventitia (94).

\section{Angiotensin II}

Vascular generation of angiotensin II was first demonstrated by swales and Thurston (95), who reported that the amount of angiotensin II antiserum required to inhibit the exogenous angiotensin effect in sodium-loaded rats was greater than expected. These authors reported that these data could not be explained solely by alterations in the angiotensin receptor sensitivity, and attributed the effects to the local synthesis of Angll. More evidence for local angiotensin production came from the observation that AngII persists in the plasma of binephrectomized rats, at model in which the plasma renin level is low (96). Also, in the chronic phase of the two-kidney, one clip ( $2 \mathrm{~K}, \mathrm{C}$ ) model of hypertension the renin activity is almost normal, while both the vascular ACE activity (97) and the ACE mRNA expression in the rat aorta remain high (98). This suggests that an increased vascular Angll concentration is responsible for the chronic hypertension.

In culture also, endothelial cells were shown to secrete angiotensins $\mathbb{I I}$ and $\mathrm{III}$, showing that these cells have at least the capacity to produce Angll (99).

\section{Angiotensin II receptors}

The recent discovery of selective, high affinity nonpeptide antagonists has resulted in the identification of distinct AII receptor subtypes. At least two major subtypes are suggested to exist with a differential tissue distribution and functional responses, the $A T_{1}$ and $\mathrm{AT}_{2}$ receptor (100-102). $\mathrm{AT}$, receptor have been cloned from rat aortic vascular smooth muscle cells, rat kidney and rat adrenal gland (103-105), bovine adrenal gland (106), and human liver (107, 108). Differences in the amino acid sequence of the AT, receptor cloned from the rat aorta $S M C$, kidney and adrenal gland has led to a further subclassification of the $A T_{1}$, receptor in $A T_{1 A}$ (rat: vascular, rat renal) and $A T_{1 B}$ (rat adrenal) receptor subtypes, which have a $96 \%$ homology in amino acid sequence (109). In the adult rat the aorta contains both $\mathrm{AT}_{1}$ and $\mathrm{AT}_{2}$ receptors $(80 \%$ and $20 \%$, respectively) $(110,111)$. In the aorta of fetal and young rats $\mathrm{AT}_{2}$ receptors are predominant (10), while the neointima of the rat thoracic aorta 15 days after balloon injury mainly expresses $A T_{1}$ receptors (11.1).

The $\mathrm{AT}_{1}$ receptor is sensitive to guanosine triphosphate (GTP) and stimulation of the receptor causes the generation of inositol $1,4,5$ triphosphate (IP, and a transient increase in $\mathrm{Ca}^{2+}$. These functional properties and the structure of the $\mathrm{AT}$, 
receptor protein consisting of 7 transmembrane domains are similar to the known characteristics of $\mathrm{G}$ protein coupled receptors. All the known Angll induced biological effects, such as secretion of aldosterone and catecholamines from the adrenal gland, central nervous responses, release of cathecholamines from sympathetic ganglia, and vasoconstriction are mediated via the $\mathrm{AT}_{1}$ receptor 1100 , $112,113)$.

No functional role for the $A T_{2}$ receptor has yet been found $(114,115)$. However, the $\mathrm{AT}_{2}$ receptor has been shown to stimulate protein tyrosine phosphatase activity, implying that this receptor might affect cellular growth and development (116).

\subsubsection{Effects of angiotensin II}

Angiotensin III was first identified as a powerful vasopressor $(117,118)$. In addition to the vasoconstrictor action, Angll serves multiple functions by acting on receptor sites in various organs. Some important functions are summarized in figure 1.2, but are not further discussed here. In this thesis we will concentrate on the effects of AngII on the vascular SMC growth.

Figure 1.2 Major functions of angiotensin II (119)

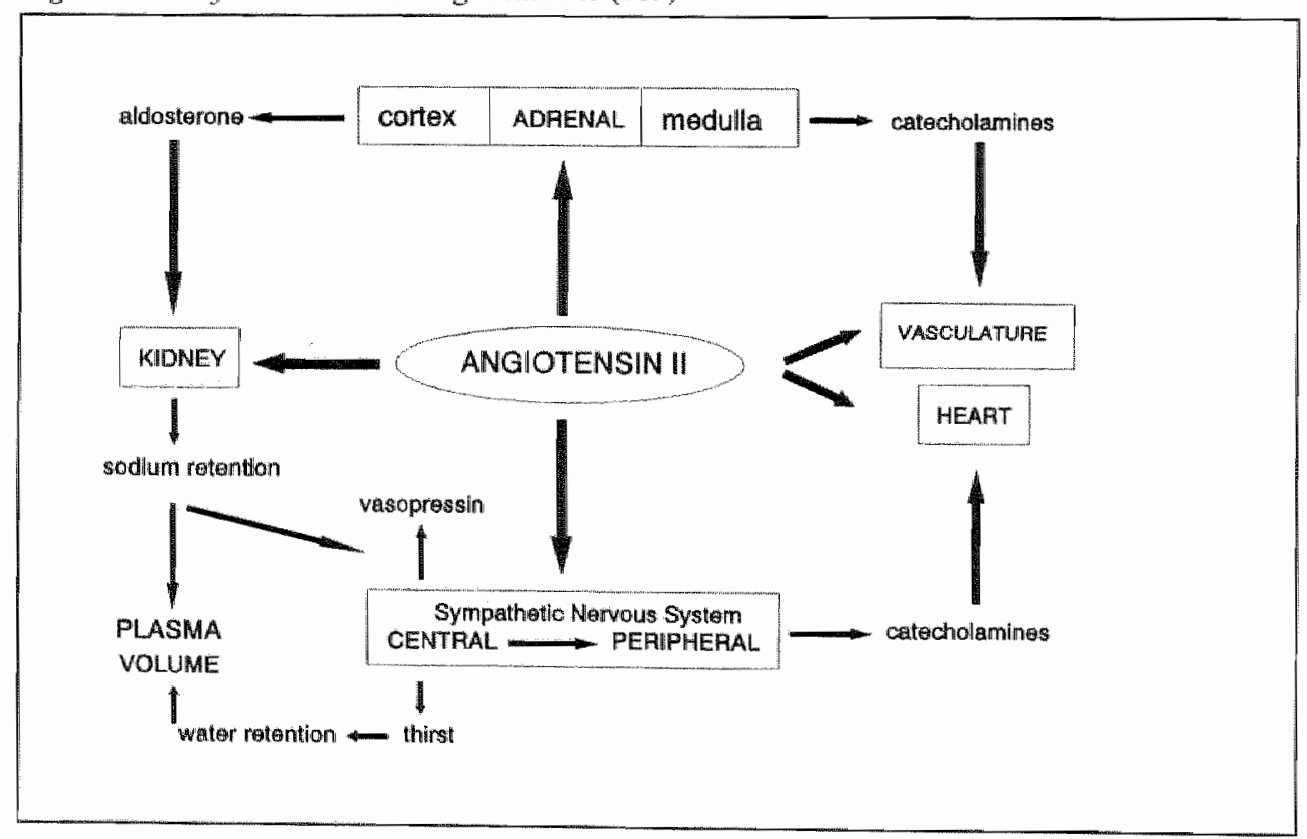


In vitro smooth muscle cell growth effects

Administration of AnglI to SMC in culture induces a variety of effects. When I $\mu \mathrm{M}$ AngIl is added to rat aortic SMC made quiescent in defined serum-free medium, there is a rapid increase in the expression of c-fos (120), c-myc (121) and c-jun mRNA (122), which is followed by an increase in protein synthesis and cell size, but not an increase in cell number $(123,124)$. Also, the administration of 1 $\mu \mathrm{M}$ Angll to an organoid culture of renal artery segments does not stimulate medial SMC proliferation, but induces media hypertrophy (125). The expression of transcription factors as c-fos, c-myc, c-jun appears to be necessary for the Angll induced hypertrophy, since anti-sense oligonucleotides to c-fos cDNA block the AngII induced protein synthesis (126). Besides the AngII induced expression of transcription factors, Angll stimulates the synthesis of platelet derived growth factor-A (PDGF-A) mRNA. PDGF-A may function as an autocrine growth factor (121), since antisense oligonucleotides to PDGF-A mRNA attenuate the Anglf induced SMC hypertrophy (127).

In culture, AngIl also stimulates the autocrine production of transforming growth factor-beta $a_{1}\left(T G F-\beta_{1}\right)$ mRNA (128). TGF- $\beta_{1}$ itself has a bifunctional effect: it eiter stimulates, or inhibits SMC proliferation (129-131). Blockade of the Angll induced TGF- $B_{1}$, production by administration of selective TGF- $B_{1}$ antibodies enhanced SMC DNA synthesis and cell number. Thus, the inactivation of TGF- $\beta_{1}$ results in the full induction of the proliferative pathway, which is probably mediated via autocrine PDGF production $(130,131)$ (figure 1.3).

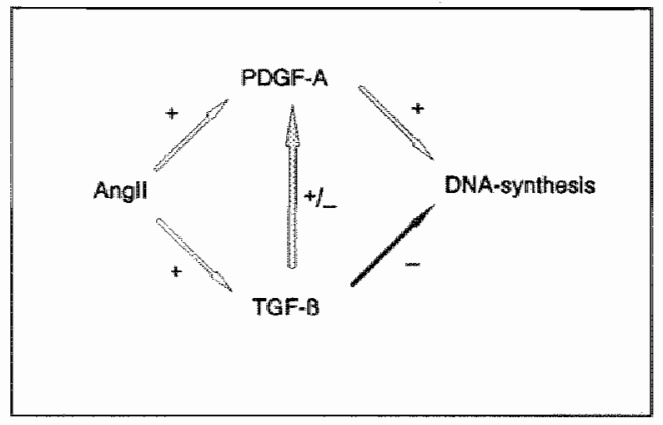

Figure 1.3 In witro effects of the interaction between Angll and TGF $-\beta_{\|}$on SMC DNA synthesis.

$+=$ stimulation; $-=$ inhibition.

Another "trophic" effect of AngIl on cultured rat aortic SMC is stimulation of the synthesis and secretion of extracellular matrix proteins, such as collagen I, III and $V$, fibronectin (132), thrombospondin (133) and tenascin (134).

In vivo vascular growth effects

The first evidence for a role of AnglJ as a possible smooth muscle cell growth factor came from studies in the Angll dependent two kidney, one clip hypertension model, where a higher frequency of polyploid $\mathrm{SMC}$ in the thoracic aorta was 
found, suggesting that increased plasma levels of Angll cause SMC DNA synthesis (135). More indirect evidence for a role of Angll as a vascular growth factor is provided by ACE inhibitor studies. In spontaneously hypertensive rats (SHR), the ACE inhibitor captopril reduced the aortic SMC volume and number of polyploid SMC more than two other drugs, hydralazine and propranolol, that caused a similar lowering of the blood pressure (136). Infusion of the ACE inhibitors captopril and cilazapril from 2 days before balloon injury until 14 days after balloon injury inhibits neointimal thickening of rat carotid artery $(137,138)$.

Infuision of AngII 2 weeks after balloon injury results in an increased SMC replication in both media and neointima of the thoracic aorta and carotid artery $(19,139)$. Angll infusion also induces hypertrophy of the rat superior mesenteric aurtery, which is not prevented by concomitant blood pressure lowering with hydralazine (140). Recently, it was demonstrated that also small arteries and arterioles in the kidney respond to Angll infusion by an increased SMC proliferation (141). More direct evidence for the rolle of Angll came from studies with AT receptor blockers. Infusion of the highly selective $\mathrm{AT}$, receptor blocker losartan 2 days before balloon injury until 14 days after balloon injury, reduced neointimal thickening after 2 weeks (142). Prescott et al. (16) compared the effect of ACE inhibition and $\mathrm{AT}_{\text {, }}$ receptor blockade on medial SMC proliferation, SMC migration, and formation of neointima, and concluded that ACE inhibition reduces neointima formation by inhibition of SMC migration. Angiotensin converting enzyme does not only cleave angiotensin 1 , but it is also known to cleave endogenous kinins (71). Therefore, the effects of ACE inhibitors may not only be due to the suppression of Angll formation but also the reduction in the degradation of endogenous kinins (figure 1.4). This latter possibility is supported by the observations that administration of the kinin antagonist Hoe 140 partially reversed the antiproliferative effect of the ACE inhibitor ramipril $(143,144)$, and that bradykinin reduces SMC proliferation in culture (54-56).

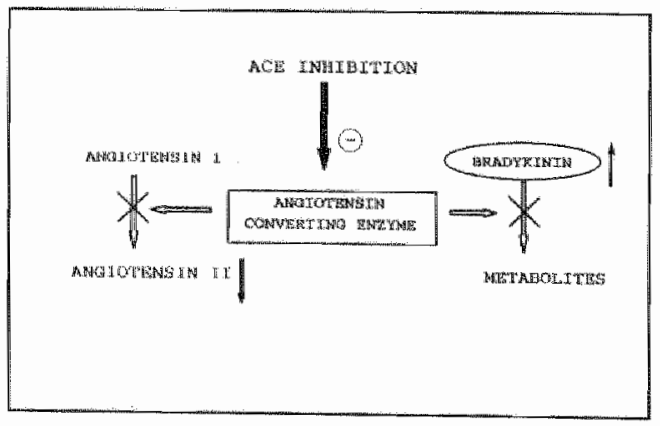

Figure 1.4 Effects of $\mathrm{ACE}$ inhibition on Angll formation and kinin metabolism. 
Besides the effects on SMC DNA synthesis and hypertrophy, Angll also modulates the mRNA expression of extracellular matrix components. Angll infusion in the thoracic aorta of normotensive rats for 3 or 10 days caused a 2 -fold increase of fibronectin mRNA expression, but had no effect on collagen $\alpha_{1}(1)$ mRNA and $e-$ lastin mRNA (145). Indirect cvidence from ACE inhibitor studies does suggest however, that AngII also influences collagen and elastin protein expression. Treatment of young ( 4 or 10 week old) normotensive rats with the $\mathrm{ACE}$ inhibitor enalapril caused a marked decrease in both large (aorta, renal and carotid artery) and smaller arteries (mesenteric) in elastin and collagen protein content(146).

Besides the effects of Angll on the vascular smooth muscle cell, Angll has also growth stimulating effects on endothelial cells by inducing angiogenesis in the rabbit cornea (147) and the chicken chorioallantoic membrane (148).

\subsubsection{Regulation of AngII induced vascular growth effects in vivo and the role of the $\alpha_{1}$-adrenoreceptor.}

Although there is convincing evidence that Angll has trophic effects on vascular growth, it is not known how AngII stimulates vascular growth. A variety of mechanisms have to be considered:

1. direct effects through angiotensin II receptor stimulation on the vascular SMC;

2. indirect effects
a. through blood pressure elevation;
b. through stimulation of the sympathetic nervous system;
c. through stimulation of other growth regulatory systems;

ad 1. Angiotensin II receptor stimulation

Both $\mathrm{AT}_{1}$ and $\mathrm{AT}_{2}$ receptors have been demonstrated on the vascular $\mathrm{SMC}$. Evidence for a role of the $A T$, receptor in $\mathrm{SMC}$ growth comes from both in witro and in vivo studies with AT, receptor blockers. In cultured aortic smooth muscle cells derived from both normotensive and spontaneousy hypertensive rat strains 10 HM losartan blocks the Angll mediated increases in protein synthesis and DNA synthesis (149-151). In vivo, losartan inhibits medial SMC replication in the carotid artery by $53 \% .4$ days after balloon injury (16). Losartan also reduces neointimal thickening after balloon injury, when administered from the time of injury (142).

ad 2a. Blood pressure elevation

Infusion of AnglI induces a blood pressure increase, caused by a wasoconstrictor effect of the molecule. A low dose of Angll induces a slowly developing pressor effect $(125,152,153)$. In an other study it was shown that Angl infusion in rats causes SMC hypertrophy in the superior mesenteric arteries. However, the SMC hypertrophy could not be attributed to the blood pressure increase, since subsequent 
blood pressure lowering by cotreatment with hydralazine did not prevent the Angil induced stuctural changes (140), suggesting that Angll can mediate vacular growth effects independent of changes in blood pressure rise.

\section{ad $2 \mathrm{~b}$. Stimulation of the sympathetic nervous system}

It is known for many years that AngIl interacts with the sympathetic nervous system at several levels. AngII may act on the brain to increase sympathetic outflow, act on the sympathetic ganglia and adrenal medulla to increase the release of catecholamines, and act on the sympathetic nerve terminals to stimulate to release of norepinephrine (154). The adrenergic innervation of blood vessels is found in the inner adventitia and adventitial-medial junction, as a plexus surrounding the tunica media (155). Exogenously administered AngII can facilitate peripheral adrenergic function (156) through $\mathrm{AT}_{\text {, }}$ receptors present on the adrenergic nerve terminals (115). This results in an increased release of noradrenaline from adrenergic nerve terminals $(157,158)$, and subsequent stimulation of postjunctional $\alpha_{1}$-adrenoreceptors (figure 1.5 ).

Figure 1.5 Interaction between Angll and a sympathetic nerve terminal.

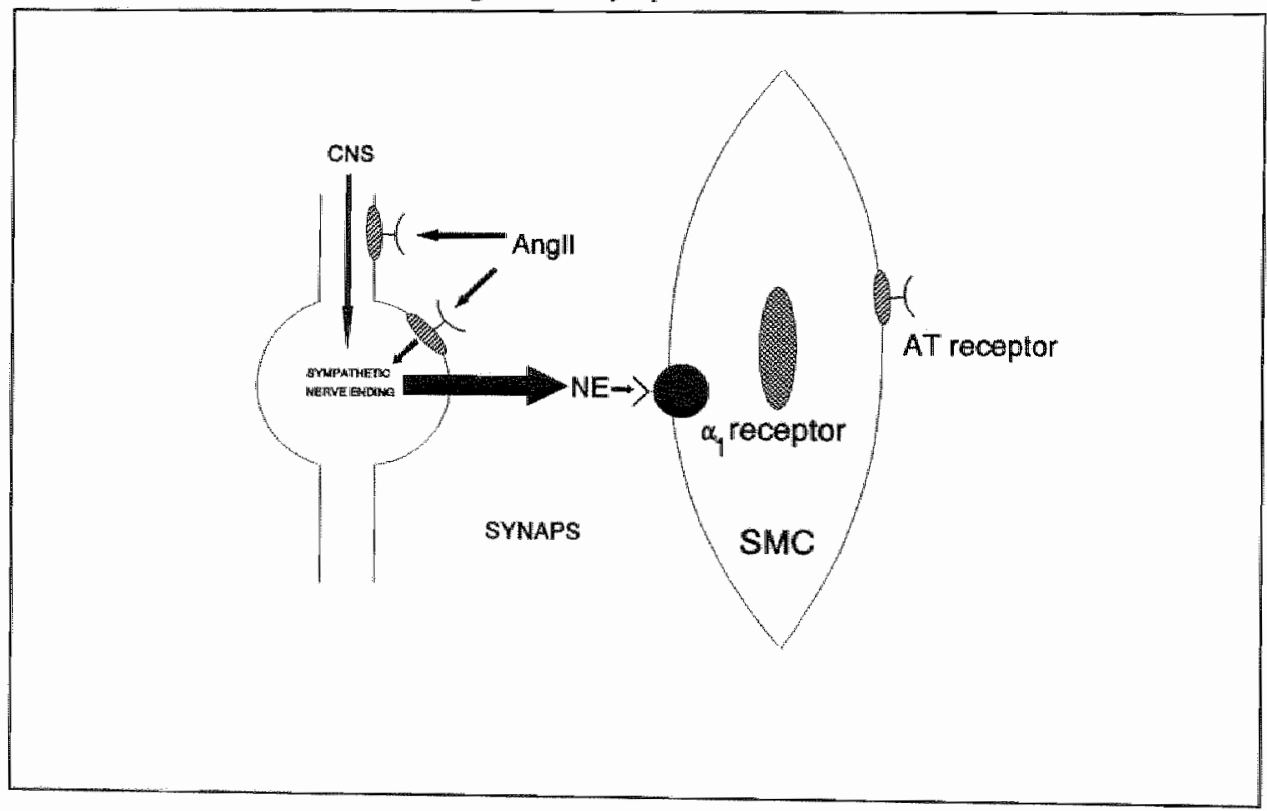

Furthermore, the sympathetic nervous system itself can exert a trophic influence on the vascular smooth muscle cell during growth (155). Unilateral removal of the superior cervical ganglion in a 4 week old rabbit decreases the amount of SMC 
DNA synthesis, wall thickness and total weight of the denerwated ear artery. The vessel wall has a decreased distensibility and is hypersensitive to norepinephrine (159). Sympathectomy also attenuates the hypertrophic response of cerebral arteries in young spontaneously hypertensive rats, whereas the opposite is found in vessels of the adult animal (160).

In vitro, administration of catecholamines to rat aortic SMC lleads to DNA synthesis (161, 162), mediated through $\alpha_{1}$-adrenoreceptors (163). In vivo, administration of a bolus injection of the $\alpha_{1}$-adrenoreceptor agonist phenylephrine does not result in SMC DNA synthesis, despite an increase in c-fos, c-myc mRNA (164), and ornithine decarboxylase mRNA and activity (164, 165). Phenylephrine injection produced a transient increase in PDGF-A mRNA expression in rat thoracic aorta, suggesting that other growth regulatory systems might be stimulated by $a_{1}$-adrenoreceptor stimulation.

ad 2c. Stimulation of other growth regulatory systems

As described in the previous section Angll can influence vascular growth indirectly through interacting with the sympathetic nervous system, but another possible indirect mechanism is the stimulation of the production and release of other polypeptide growth factors. This interaction with other growth regulatory systems was already indicated in a previous section where we described that Angll induces TGF- $B$, mRNA expression with subsequent induction of other autocrine regulatory factors, such as PDGF-A in vitro (128) (see figure 1.3). This might also be an important regulatory system in vivo, since $T G F-B_{1}$ is found to be highly expressed in neointima of the balloon injury model and TGF-B, infusion stimulates neointimal proliferation (20).

Thus, the existing data on SMC growth via AngII indicate that Angll can indeed induce DNA synthesis. The data suggest that this response is mediated via the AT, receptor and not blood pressure mediated. Furthemore, Angll seems to interfere with a variety of other systems that are possibly involved in growth regulation. This complex of possibilities might explain the heterogeneity of the effect of Angll in different investigations.

\subsection{HYPOTHESIS}

We investigated mechanisms of angiotensin II induced SMC DNA synthesis in the normal media and the neointima formed after balloon injury.

In our hypothesis the effects of Angll on SMC DNA synthesis are indirect, independent of blood pressure changes, and involve the $\alpha_{1}$-adrenoreceptor as well as other growth regulatory systems. The $\alpha_{1}$-adrenoreceptor may be involved in several ways by for instance stimulation of the release of norepinephrine at the 
sympathetic nerve endings, through increased central sympathetic stimulation, or stimulation of the release of catecholamines from adrenal gland by angiotensin $\mathbb{I I}$. In our hypothesis Angll and the $\alpha_{1}$-adrenoreceptor cooperate in a parallel and not in a serial fashion (figure 1.6). Thus, $\alpha_{1}$-adrenoreceptor stimulation alone is not necessarily mitogenic. In analogy with the increased sensitivity of the neointimal SMC to AngII we hypothesized that neointimal cell are more sensitive to $\alpha_{1}$ adrenoreceptor agonists.

The AnglI induced stimulation of AT receptors and $\alpha_{1}$-adrenoreceptors also affects other growth regulatory systems, like PDGF-A and TGF- $B_{1}$. The sum of the effects of the stimulation (or inhibition) of these systems determines the final outcome of AngII infusion. Furthermore, AngII is not only mitogenic for SMC but has also stimulatory effects on the production of extracellular matrix (ECM) proteins. The regulation of the latter effect is different from the regulation of AngII induced SMC DNA synthesis.

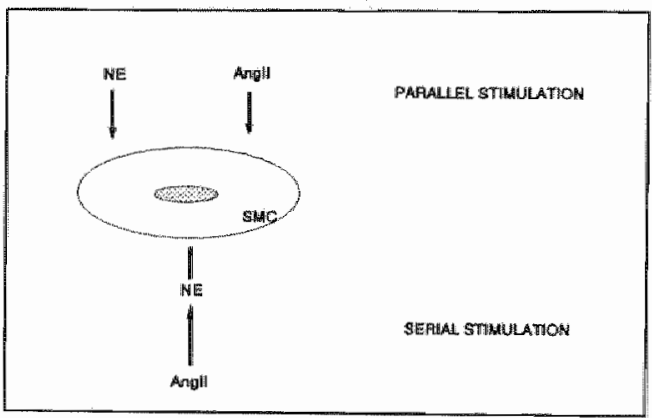

Figure 1.6 Schernatic drawing of a model for the involvement of the $\alpha_{n}$-adrenoreceptor in the induction of SMC DNA synthesis by Angll.

\subsection{AIM OF THIS STUDY}

The aims of the studies presented in this thesis are to investigate the mechanisms of angiotensin II induced growth responses of the vascular SMC in vivo, with particular emphasis on the involvement of the $\alpha_{1}$-adrenoreceptor in this response. We focused on vascular SMC DNA synthesis and ECM production in the normal media and in the neointima after injury.

The first experimental chapter (chapter 3) is a validation of the BrdUrd labeling method to measure DNA synthesis. The results obtained with SMC BrdUrd labeling are compared with the results obtained with SMC $\left[{ }^{3} \mathrm{H}\right]$ thymidine labeling in the same rat.

To investigate the regulation of AngII induced SMC DNA synthesis, several possible pathways are investigated using pharmacological interventions. The interaction of Angll with the sympathetic nervous system is investigated in 
chapters 4,5 and 6. In chapter 4 and 5 these effects are studied in normal, non balloon injured arteries, whereas in chapter 6 these are studied in the balloon injured common carotid artery. In chapter 4 the specific $\alpha_{4}$-adrenoreceptor antagonist prazosin is used to explore the role of $\alpha_{1}$-adrenoreceptor in the Angll induced SMC DNA synthesis in the thoracic aorta. In chapter 5 a possible heterogeneous effect of AngII infusion on SMC DNA synthesis is investigated. The AngII induced growth response is measured in four elastic arteries: the carotid, renal, femoral and superior mesenteric artery. The role of the $\alpha_{1}$-adrenoreceptor in the AngII induced SMC DNA synthesis in these arteries is analyzed by coinfusion of the $\alpha_{1}$-adrenoreceptor antagonist prazosin. In chapter 6 the role of the $\alpha_{1}$ adrenoreceptor in the AngIl induced stimulation of neointima formation after balloon injury of the rat carotid artery is investigated by using another $\alpha_{1}$-adrenoreceptor antagonist, doxazosin. In chapter 7 the vascular smooth muscle cell DNA synthesis in response to intusion of the $\alpha_{4}$-adrenoreceptor agonist phenylephrime is studied in young, developing WKY rats and compared with the SMC DNA synthesis in age matched WKY rats treated with AngII. In chapter 8 phenylephrine is infused two weeks after balloon injury of the rat carotid artery to investigate the effects of stimulation of the $\alpha_{1}$-adrenoreceptor on neointimal SMC DNA synthesis. In chapter 9 the effects of AngIl on collagen and elastin mRNA and protein synthesis are investigated and compared to the balloon injured carotid artery without AngII treatment. The results of the studies described in the previous chapters are discussed in chapter 10 . 


\section{RERERENCES}

1. Grünzigs, AR; Sening, A; Siegenthaler, WE: Nonoperative dilatation of coronary-artery stenosis: percutancous transluminal coronary angioplasty. N Engl I Med 1979;301:61-68.

2. Ryaln, TJ; Faxon, DP; Gunnar, RM; Kennedy, JW; King, SB, 3d; Loop, FD; Peterson, KL; Reveves, TJ; Williams, DO; Winters, WL, Jr; et al: Guidelines for percutaneous transluminal coromary angioplasty. A report of the American College of Cardiology/American Heart Association Task Force on Assessment of Diagnostic and Therapeutic Cardiovascalar Procedures (Subcommittee on Percutaneous Transhminal Coronary Angioplasty). Circulation $1988,78: 486-502$.

3. Liu, MW; Roubin, GS; King, SB, 3d: Restenosis after coronary angioplasty. Potential biologic determinants and role of intimal hyperplasia. Circulation 1989;79:1374-1387.

4. Nobuyoshi, M; Kimura, T; Nosaka, H; Mioka, S; Ueno, K; Yokoi, H; Hamasaki, N; Horuchi, H; Ohishi, H: Restenosis after successfu! percutaneous transluminal coronary angioplasty: serial angiographic follow-up of 229 patients. I Am Coll Cardiol 1988;12:616623.

5. Nobuyoshi, M; Kimura, T; Ohishi, H; Horiuchi, H; Nosaka, H; Hamasaki, N; Yokoi, H; Kim, K: Restenosis after percutaneous transluminal coronary angioplasty: pathologic observations in 20 patients. J Am Coll Cardiol 1991;17:433-439.

6. Sernys, PW; Luijten, HE; Beall, KI; Geuskens, R; Feyter, PI de; Brand, M van den; Reiber, IHC; Katen, HJ ten; Es, GA wan; Hugenholtz, PG: Incidence of restenosis after successful coronary angioplsty: a time-related phenomenon. Circulation 1988;77:361-371.

7. Serruys, PW; Luijten. HE; Beatt, KJ; Geuskens, R; de-Feyter, PJ; van-den-Brand, M; Reiber, JH; ten-Katen, HI; van-Es, GA; Hugenholtz, $\mathrm{PG}$ : Incidence of restenosis after successful coronary angioplasty: a time-related phenomenon. A quantitative angiographic study in 342 conseculive patients at $1,2,3$, and 4 months. Circulation 1988;77,361 371 .

8. Hermans, WR: Rensing, BJ; Stratuss, BH; Serruys, PW: Prevention of restenosis after percutaneous transluminal coronary angioplasty: the search for a "magic bullet". Am Heart J $1991: 122: 171-187$.

9. Austin, GE; Ratliff, NB; Hollman, $J$; Tabei, S; Phillips, DF: Intimal proliferation of smooth muscle cells as an explanation for recument coronary artery stenosis after percutaneous transluminal coronary angioplasty. J An Coll Cardiol 1985;6:369-375.

10. Waller, BF; Rothbaum, DA; Gorfinkel, HJ: Utbright, TM; Linnemeier, TJ; Berger, SM: Morphologic observations after percutaneous transluminal balloon angioplasty of early and late aortocoronary saphenous vein bypass grafts. J Am Coll Cardiol 1984;4:784-792.

11. O'Brien, ER; Alpers, CE; Stewart, DK; Ferguson, M; Tran, N; Gordon, D; Bendit, EP; Hinohara, T; Simpson, JB; Schwartz, SM: Proliferation in primary and restenotic coronary atherectomy tissue. Implications for antiproliferative therapy. Circ Res 1993:73:223-231. 
12. Strauss, BH: Umans, VA; Stylen, RJ wan; Feyter, PJ de: Maroo, 3; Robertson, $\mathrm{OC}$; Renkin, J; Heyndrickx, G; Vuzevski, VD; Bosman, FT; Sertuys, PW: Directional atherectomy for treatment of restenosis within coronary stents: clivical, angugraphio and histologic results. J Am Coll Cardiol 1992;20;1465-1473.

13. Pickering, JG; Weir, L; Jekanowski, J; Keaney, MA; Isner, JM: Proliferative activity in peripheral and coronary atheroselerotic plaque among patients undergoing percutaneous revascularization. J Clin Invest 1993;91:1469-1480.

14. Baumgartner, H-R: Eine neve Methode zur Erzeugung von Thromben durch gezielte Überdehmung der Gefaswänd. $\mathbb{Z}$ ges exp Med 1963;137:227-247.

15. Clowes, AW; Reidy, MA; Clowes, MM: Kinetics of cellular proliferation after arterial injury. 1. Smooth muscle growth in the absence of endothelium. Lab Invest 1983;49:327333.

16. Prescott, MG; Webb, RL; Reidy, MA: Angiotensin-converting enzyme inhibitor versus angiotensin II, ATl receptor antagonist. Effects on smooth muscle cell migration and proliferation after balloon catheter injury. Am J Pathol 1991;139:1291-1296.

17. Unger, $T$; Gohlke, $P$; Ganten, $D$; Lang, $R E$; Converting enzyme inhibitors and their effects on the renim-angiotensin system of the blood vessel wall. I Cardiovase Pharmacol $1989 ; 13: 58-516$.

18. Clowes, AW; Schwartz, SM: Signilicance of quiescent smooth muscle migration in the injured rat carotid artery. Circ Res 1985;56:139-145.

19. Datenen, Ms; Lombardi, DM; Bosman, FT; Schwartz, SM: Angiotensin II induces smooth muscle cell proliferation in the normal and injured rat arterial wall. Circ Res 1991;68:450456.

20. Majesky, MW; Lindner, V; Twardzik, DR; Schwartz, SM; Reidy, MA: Production of transforming growth factor beta 1 during repair of arterial injury. I Clin Invest $1991: 88: 904-910$.

21. Clowes, AW; Clowes, MM; Reidy, MA: Kinetics of cellular proliferation after arterial injury. III. Endothelial and smooth muscle growth in chronically denuded vessels. Lab Invest 1986;54:295-303.

22. Snow, AD; Bolender, RP; Wight, TN; Clowes, $A$ W: Heparin modulates the composition of the extracellular matrix domain surrounding arterial smooth muscle cells. Am I Pathol $1990 ; 137.313-330$.

23. Boyd, CD; Kniep, AC; Pierce, RA; Deak, SB; Karboski, C; Miller, DC; Parker, MI; Mackenzie, IW; Rosenbloom, J; Scott, GE: Increased elastin mRNA levels associnted with surgically induced intimal injury. Conn Tiss Res 1988;18:65-78.

24. Barnes, M. Collagens in Atherosclerosis. Collagen Rel Res 1985;5:65-97. 
25. Reidy, MA; Clowes, AW; Schwartz, SM: Endothelial regeneration. V. Inhibition of endothelial regrowh in arteries of rat and rabbit. Lab Invest 1983;49:569-575.

26. Lindner, $V$; Reidy, MA; Fingerle, $J$ : Regrowth of arterial endothelium. Denudation with minimal trauma leads to complete endothelial cell regrowth. Lab Invest 1989;61:556-563.

27. Ross, R: The pathogenesis of atherosclerosis-m an update. N Engl J Med 1986;314:488-500.

28. Fingerle, J; Johnson, $R$; Clowes, AW; Majesky, MW; Reidy, MA: Role of platelets in smooth muscle cell proliferation and migration after vascular injury in rat carotid artery. Proc Natl Acad Sci USA 1989;86:8412-8416.

29. Clowes, AW; Clowes, MM: Kinetics of cellular proliferation after arterial injury. IV. Heparin imhibits rat smooth muscle mitogenesis and migration. Circ Res 1986;58:839-845.

30. Reidy, MA; Silwer, M: Endothelial regeneration. VIl. Lack of intimal proliferation after defined injury to rat aorta. Am J Pathol 1985:118:173-177.

31. Jawien, A; Bowenpope, DF; LLindner, V; Schwartz, SM; Clowes, AW: Platelet-derived growth factor promotes smooth muscle migration and intimal thickening in a rat model of balloon angioplasty. J Clin Invest 1992;89:507-511.

32. Ferns, GA; Raines, EW; Sprugel, KH; Motani, AS; Reidy, MA; Ross, R: Inhibition of neointimal smooth muscle accumulation after angioplasty by an antibody to PDGF. Science $1991 ; 253: 1129-1132$.

33. Lindner, V; Lappi, DA; Baird, A; Majack, RA; Reidy, MA: Role of basic fibroblast growth factor in vascular lesion formation. Circ Res 1991;68:106-113.

34. Lindner, V; Majack, RA; Reidy, MA: Basic fibroblast growth factor stimulates endothelial regrowth and proliferation in dentuded arteries. I Clin Invest 1990;85:2004-2008.

35. Edelman, ER; Nugent, MA: Smith, LT; Karnovsky, MJ: Basic fibroblast growth factor enhances the coupling of intimal hyperplasia and proliferation of vasa vasorum in injured rat arteries. J Clin Inwest 1992;89;465-473.

36. Lindner, $\mathrm{V}$ : Reidy, MA: Proliferation of smooth muscle cells after vascular injury is inhibited by an antibody against basic fibroblast growth factor. Proc Natl Acad Sci USA $1991: 88: 3739-3743$

37. Olson. NE; Chao, S; Lindner, V; Reidy, MA: Intimal smooth muscle cell proliferation after balloon catheter injury. The role of basic fibroblast growth factor. Am J Pathol $1992 ; 140: 1017-1023$.

38. Bell, L; Madri, JA: Effect of platelet factors on migration of cultured bovine aortic endothelial and smooth muscle cells. Circ Res 1989;65:1057-1065. 
39. Majesky, MW; Schwartz, SM; Clowes, MM; Clowes, AW: Heparin regulates snnooth muscle $S$ phase entry in the injured rat carotid artery. Circ Res 1987;61:296-300.

40. Clowes, AW; Clowes, MM; Vergel, SC; Muller, RK; Powell, JS; Hefti, F; Baumgartner, HR: Heparin and cilazapril together inhibit injury-induced intinal hyperplasia. Hypertension 1991;18(Suppl.4):1165-1169.

41. Reilly, CF; Kindy, MS; Brown, KE; Rosenberg, RD; Sonenshein, GE: Heparin prevents vascular smooth muscle cell progression through the GI phase of the cell cycle. I Biol Chem 1989;264:6990-6995.

42. Simons, M; Edelman, ER; DeKeyser, $\mathbb{I L}$; Langer, R; Rosenberg, RD: Amtisense c-myb olgonucleotides inhibit intimal arterial smooth muscle cell accumulation in vivo. Nature $1992 ; 359: 67-70$.

43. Huang, $\mathrm{CL}$; Takenawa, $\mathrm{T}$; Ives, HE: Platelet-derived growth factor-mediated $\mathrm{Ca} 2+$ entry is blocked by antibodies to phosphatidylinositol 4,5-bisphosphate but does not involve heparin-sensitive inositol 1,4,5-trisphosphate receptors. J Biol Chem 1991:266:4045-4048.

44. Kobayashi, S; Kitazawa, T; Somlyo, AV; Somlyo, AP: Cytosolic heparin inhibits muscarinic and alpha-adrenergic $\mathrm{Ca}+$ release in smooth muscle. Physiological role of inositol 1,4,5-trisphosphate in pharmacomechanical coupling. J Biol Chem $1989 ; 264: 17997-18004$.

45. Lindner, $\mathrm{V}$; Olson, $\mathrm{NE}$; Clowes, $\mathrm{AW}$; Reidy, MA: Inhibition of smooth muscle cell proliferation in injured rat arteries. Interaction of heparin with basic fibroblast growth factor. J Clin Invest 1992;90:2044-2049.

46. Jackson, CL; Bush, RC; Bowyer, DE: Mechanism of antiatherogenic action of calcium antagonists. Atherosel 1989;80:17-26.

47. Handley, DA; Van-Valen, RG; Melden, MK; Saunders, RN: Suppression of rat carotid lesion development by the calcium channel blocker PN 200-110. Am $J$ Pathol $1986 ; 124: 88-93$.

48. Block, LH; Emmons, LR; Vogt, E; Sachinidis, A; Vetter, W; Hoppe, J: Ca2tochannell blockers inhibit the action of recombinant platelet-derived growth factor in vascular smooth muscle cells. Proc Natl Acad Sci USA 1989;86:2388-2392.

49. Furchgott, RF; Vanhoutte, PM: Endothelium-derived relaxing and contracting factors. Faseb J 1989;3:2007-2018.

50. Moncada, S; Palmer, RM; Higgs, EA: Biosynthesis of nitric oxide from L-arginine. A pathway for the regulation of cell function and communication. Biochem Pharmacol $1989 ; 38: 1709-1715$. 
51. Ignarro, Lf; Buga, GM; Wood, $\mathbb{K S}$; Byrns, RE; Chaudhuri, $G$; Endohelfum-derived relaxing factor produced and released from artery and vein is mitric oxide. Proc Natl Acad Sci USA 1987:84:9265-9269.

52. Hogan, JC, Lewis, $\mathrm{M}$; Henderson, $\mathrm{AH}$ : In vivo EDRF activity influences platelet function. $\mathrm{Br}$ I Pharmacol 1988;04:1020-1022.

53. Joly, GA; Schini, VB; Vanhoutte, PM: Balloon injury and interletkin-1 beta induce nitric oxide synthase activity in rat carotid arteries. Circ Res 1992;71:331-338.

54. Garg, UC; Hassid, A: Nitric oxide-generating vasodilators and 8-bromo-cyclic guanosine monophosphate inhibit mitogenesis and proliferation of cultured rat vascular smooth muscle cells. J Clin Invest 1989;83:1774-1777.

55. O'Connor, $\mathrm{KF}$; $\mathrm{Knowles,} \mathrm{RG}$; Patel, $\mathrm{KD}$. Nitrovasodilators have proliferative as well as antiproliferative effects. I Cardiovasc Pharmacol 1991;17(Suppl.3):S100-S103.

56. Assender, JW; Southgate, KM; Newby, AC: Does witric oxide inhibit smooth muscle proliferation? \& Cardiovase Pharmacol 1991;17(Suppl.3):S104-S107.

57. Mey, JGR de; Dijkstra, EH; Vrijdag, MJJF: Endothelium reduces DNA synthesis in isolated arteries. Am J Physiol 1991;260:H1128-1134.

58. Schiffers, PMH; Fazzi, GE; Ingen Schenau, D van; Mey, JGR de: Effects of candidate autocrine and paracrine mediators on growtl responses in isolated arteries of the rat. submitted.

59. Langille, BL; O'Donnell, F: Reductions in arterial diameter produced by chronic decreases in blood flow are endothelium-dependent. Science 1986;231:405-407.

60. Kohler, TR; Kirkman, TR; Kraiss, LW; Zierler, BK; Clowes, AW: Increased blood flow inhibits neointimal hyperplasia in endothelialized vascular grafts. Circ Res 1991;69:15571565.

61. Kohler, TR; Jawien, A: Flow affects development of intimal hyperplasia after arterial injury in rats. Arterioscler Thromb 1992;12:963-971.

62. Goodfiend, TL: Angiotensins. A family that grows from within. Hypertension $199: 17: 139-140$.

63. Oliver, JA; Sciacca, RR: Local generation of angiotensin II as a mechanism of regulation of peripheral wascular tone in the rat. J Clin Invest 1984;74:1247-1251.

64. Mizuno, K; Nakamura, M; Higasthimori, K; Inagami, T: Local generation and release of angiotensin II in peripheral vascular tissue. Hypertension 1988;11:223-229.

65. Campbell, DJ: Circulating and tissue angiotensin systems. J Clin Invest 1987;79:1-6. 
66. Unger, $T$; Badoer, E; Ganten, D; Lang, RE; Rettig, R: Brain angiotersin: pathways and phamacology. Circulation 1988;77(Suppl.1):14010154.

67. Dzau, VJ; Safar, ME: Large conduit arteries in thypertension: role of the vascular reninangiotensin system. Circulation 1988:77:947-954.

68. Dzau, VI: Tissue renin-angiotensin system: physiologic and pharmacologic implications. Introduction. Circulation 1988;77(Suppi.1):11-13.

69. Admiraal, PJJ; Danser, AHJ; Derkx, FHM; Sehalekamp, ADH: Angiotensin II production in different vascular beds in hypertensive subjects. J Hypertens 1991:9 (Suppl.6):S208\$209.

70. Ehlers, MR; Riordan, JF: Angiotensin-comwerting enzyme: new concepts concerning its biological role. Biochem 1989;28:531]-5318.

71. Erdos, EG; Angiotensin 1 converting enzyme and the changes in our concepts through the years. Lewis K. Dahl memorial lecture. Hypertension 1990;16:363-370.

72. Okunishi, H; Miyazaki, M; Okamura, T; Toda, $N$ : Different distribution of two types of angiotensin II-generating enzymes in the atortic wall. Biochem Biophys Res Commun $1987 ; 149: 1186-1192$

73. Urata, H; Healy, B; Stewart, RW; Bumpus, FM; Husain, A: Angiotensin II-foming pathways in normal and failing human hearts. Circ Res 1990;66:883-890.

74. Ideishi, M; Sasaguri, M; Ikeda, M; Arakawa, K: Substrate-dependent angiotensin II formation in the peripheral circulation. Life Sei 1990;46:335-341.

75. Dzau, V』: Multiple pathways of angiotensin production in the blood vessel wall: evidence, possibilities and hypotheses. J Hypertens 1989;7:933-936.

76. Eggena, P; Krall, F; Eggena, MP; Clegg, K; Fittingoff, M; Barrett, ID: Production of angiotensinogen by cultured rat aortic senooth muscle cells. Clin Exp Hypertens A $1990: 12: 1175-1189$.

77. Lynch, KR; Simnad, VI; Ben-Ari, ET; Garrison, JC: Localization of preangiotensinogen messenger RNA sequences in the rat brain. Hypertension 1986:8.540-543.

78. Campbell, DJ: Habener, JF: Cellular localization of angiotensinogen gene expression in brown adipose tissue and mesentery: quantification of messenger ribonucleic acid abundance using hybridization in situ. Endoer 1987:121:1616-1626.

79. Cassis, LA; Lynch, KR; Peach, MY: Localization of angiotensinogen messenger RNA in rat aorta. Cire Res 1988;62:1259-1262. 
80. Naftilan, AJ: Zuo, WM: Inglefinger, J; Ryan, TJ, Jr; Pratt, RE; Dzau, VJ: Localization and differential regulation of angiotensinogen mRNA expression in the vessel wall. I Clin Invest $1991,87: 1300-1311$.

81. Rakugi, H; Jacob, HJ; Krieger, IE; Ingelfinger, F2R; Pratt, RE: Vascular injury induces angiotensinogen gene expression in the media and neointima. Circulation 1993;87:283290.

82. Re, R; Fallon, JT; Drau, VJ; Quay, $\mathrm{SC}$; Haber, E: Renin synthesis by canine aortic smooth muscle cells in culture. Life Sci 1982;30:99-106.

83. Dzau, VJ: Vescular renin-angiotensin: A possible autocrine or paracrine system in control of vascular function. J Cardiovasc Phamacol 1984;6(Suppl.2):5377-5382

84. Lilly, LS; Pratt, RE; Alexander, RW; Larson, DM; Ellison, KE; Gimbrone, MA; Dzau, VJ: Renin expression by vascular endothelial cells in culture. Circ Res 1985;57:312-318.

85. Dzau, VJ: Vascular angiotensin pathways: a new therapeutic target. I Cardiowasc Pharmacol 1987;10(Suppl.7):\$9-S16.

86. Rosenthal, JH; Pfeifle, B; Michailov, ML; Pschorr, J; Jacob, ICM; Dahlheim, H: Investigations of components of the renin-angiotensin system in rat vascular tissue. Hypertension 1984;6:383-390.

87. Dzau, VI: Renin-angiotensin system and arterial wall in hypertension, in: Nijhoff, M (ed.): Arterial and venous systems in essential hypertension. Amsterdam, 1987:153-164.

88. Okura, $\mathrm{T}$; Kitami, $\mathrm{Y}_{\hbar}$ Iwata, $\mathrm{T}$; Hiwada, $\mathrm{K}$ : Quantitative measurement of extra-renal renin mRNA by polymerase chain reaction. Biochem Biophys Res Commun 1991;179:25-31.

89. Holycross, BJ; Saye, J; Harrison, JK; Peach, MJ: Polymerase chain reaction analysis of renin in rat aortic smooth muscle. Hypertension 1992;19:697-701.

90. Caldwell, PRB; Seegal, BC; Hsu, KC: Angiotensin converting enzyme: vascular endothelial localization. Science 1976;191:1050-1051.

91. Ryan, US; Ryan, JW; Whitaker, C; Chiu, A: Localization of angiotensin-converting enzyme (kininase II). II. Immunocytochemistry and immunofluorescence. Tissue \& Cell $1976 ; 8: 125-146$.

92. Pipili, E; Manolopoulos, VG; Catravas, JD; Maragoudakis, ME: Angiotensin convering enzyme activity is present in the endothelium-denuded aorta. Br J Pharmacol 1989;98:333 335.

93. Egleme, C. Cressier, F; Wood, JM: Local formation of angiotensin II in the rat aorta: effect of endothelium. Br I Pharmacol 1990;100:237-240. 
94. Bruneval, P; Foumier, JG; Soubrier, F; Belair, MF; Da-Silwa, JL; Guether, C; Pinet, F; Tardivel, I; Corvol, P; Bariety, J; et al: Detection and localization of renin messenger RNA in human pathologic tissues using in situ hybridization. Am I Pathol 1988,131:320330.

95. Swalles, JD; Thurston, H: Generation of angiotensin II of peripheral vascular level: studies using angiotensin II antisera. Cli Sci Mol Med 1973:45:691-700.

96. Aguilera, $\mathrm{G}$; Catt, $\mathrm{K}$ : Regulation of vascular angiotensin II receptors in the rat during altered sodium uplake. Circ Res 1981,49:751-758.

97. Okamura, T; Miyazaki, M; Inagami, T; Toda, N: Vascular renin-angiotensin system in two-kidney, one clip hypertensive rats. Hypertension 1986;8:560-565.

98. Shiota, N; Miyazaki, M; Okunishi, H: Increase in angiotensin converting enzyme gene expression in the hypertensive aorta. Hypertension 1992;20:168-174.

99. Kifor, I; Dzau, VJ: Endothelial renin-angiotensin pathway: evidence for intracellular synthesis and secretion of angiotensins. Circ Res 1987;60:422-428.

100. Whitebread, $S$; Mele, $M_{*}$ Kamber, B; de-Gasparo, $M$ : Preliminary biochemical characterization of two angiotensin II receptor subtypes. Biochem Biophys Res Commun $1989 ; 163: 284-291$.

101. Chu, AT; Herblin, WF; McCal1, DE; Ardecky, RJ; Carini, DJ; Duncia, JV; Pease, LJ; Wong, $\mathrm{PC}$; Wexler, RR; Johnson, AL; et al: Identification of angiotensin II receptor subtypes. Biochem Biophys Res Commun 1989;165:196-203.

102. Chang, RS; Lotti, VJ: Two distinct angiotensin IT receptor binding sites in rat adrenal revealed by new selective nonpeptide ligands. Mol Pharmacol 1990;37:347-351.

103. Murphy, TJ; Alexander, RW; Griendling, KK; Runge, MS; Bernstein, KE: Isolation of a cDNA encoding the vascular type-1 angiotensin II receptor. Nature 1991;351:233-236.

104. Iwall, N; Yamano, Y; Chaki, S; Konishi, F; Bardhan, S; Tibbetts, C; Sasaki, K; Hasegawa, $\mathrm{M}$; Matsuda, $\mathrm{Y}_{\text {; }}$ Inagami, $\mathrm{T}$ : Rat angiotensin II receptor: cDNA sequence and regulation of the gene expression. Biochem Biophys Res Commun 1991;177:299-304.

105. Iwai, $N$; Inagami, $T$ : Identification of two subtypes in the rat type I angiotensin II receptor. FEBS Lett 1992;298;257-260.

106. Sasaki, K; Yamano, Y; Bardhan, S; Iwai, N; Murray, JJ; Hasegawa, M; Matsuda, Y; Inagami, T: Cloning and expression of a complementary DNA encoding a bovine adrenal angiotensin II type-1 receptor. Nature 1991;351:230-233.

107. Takayanagi, R; Ohnaka, K; Sakai, Y; Nakao, R; Yanase, T; Haji, M; Inagami, T; Furuta, $\mathrm{H}$; Gou, DF; Nakamuta, $\mathrm{M}$; et al: Molecular cloning, sequence anallysis and expression of 
a CDWA encoding human type-1 angiotensin II receptor. Biochem Biophys Res Commun $1992 ; 183: 910-916$.

108. Furuta, $H$, Guo, DF. Inagami, T: Molecular cloning and sequencing of the geme encoding human angiotersin 11 type 1 receptor. Biochem Biophys Res Commun 1992;183:8-13.

109. Inagami, T; Iwai, N; Sasaki, K; Yamamo, Y; Bardhan, S; Chaki, S; Guo, DF; Furuta, H: Cloning, expression and regulation of angiotensin II receptors. J Hypertens 1992;10:713716.

110. Viswanathan, M; Tsuisumi, $K$; Conea, FM: Saavedra, JM: Changes in expression of angiotensin receptor subtypes in the rat aorta during development. Brochem Biophys Res Commun 1991;179:1361-1367.

11. Viswanathan, M; Stromber, C; Seltzer, A; Saakedra, JM: Balloon angioplasty enhances the expression of angiotensin II ATI receptors in neointima of rat aorta. $\mathrm{J} C$ lin Invest $1992,90: 1707-1712$

112. Gehlert, DR; Gackenheimer, SL; Schober, DA: Autoradiographic localization of subtypes of angiotensin Il antagonist binding in the rat brain. Neuroscience 1991;44:501-514.

113. Timmermans, PB: Wong, PC; Chiu, AT; Herblin, WF: Nonpeptide angiotensin II receptor antagonists. Trends Pharmacol Sei 1991;12:55-62.

114. Dudiey, DT; Panek, RL; Major, TC; Lu, GH; Bruns, RF; Klinkefus, BA; Hodges, JC; Weishaar, RE: Subclasses of angiotensin II binding sites and their functional significance. Mol Pharmacol 1990;38:370-377.

115. Wong, PC; Hart, SD; Zaspel, AM; Chiu, AT; Ardecky, RJ; Smith, RD; Timmermans, PB: Functional studies of nonpeptide angiotensin II receptor subtype-specific ligands: DuP 753 (All-1) and PD123177 (All-2). J Pharmacol Exp Ther 1990;255:584-592.

16. Bottari, SP; King, IN; Reichlin, S; Dahlstroem, 1; Lydon, N; de-Gasparo, M: The angiotensin $A T 2$ receptor stimulates protein tyrosine phosphatase aclivity and mediates inhibition of particulate guanylate cyclase. Biochem Biophys Res Commun 1992;183:206$2 \|$.

117. Braun-Menä ndez, E; Fasciolo, JC; Letoir, LF; Muñoz, M: La substancia hipertensora de tha sangre del rinón isquemiado. Rev Soc Argent Biol 1939:15:420-425.

118, Page, HH; Helmer, OM: A crystalline pressor substance (angiotonin) resulting from the reaction between renim and renin-activator. Journal of Experimental Medicine 1940;71:2942.

19. Keeton, TK: Campbell, WB: Control of renin release and its alleration by drugs, in: Antonaccio MJ (ed). Cardiovascular Pharmacology, 3rd ed. New York, Raven Press, 1984, pp. 65-118. 
120. Naftilan, AJ; Pratt, RE; Eddridge, CS; Lin, HL; Dzatl, VI: Angiotensin II induces e-fos expression in smooth muscle via transeriptional control. Hypertension 1989;1,7:706-711.

121. Naftilan, AJ; Pratt, RE; Dzau, VJ: Induction of platelet-deriwed growith factor A-chain and c-myc gene expressions by angiotensin II in cultured rat vascular smooth muscle cells. I Clin Invest $1989 ; 83: 1419-1424$.

122. Naftlan, Al; Gilliland, GK; Eldridge, CS; Kraft, AS: Induction of the proto-oncogene ojun by angiotensin II. Mol Cell Biot 1990;10:5536-5540.

123. Geisterfer, AA; Peach, MJ; Owers, GK: Angiotensin II induces hypertrophy, not hyperplasia, of cultured rat aortic snooth muscle cells. Circ Res 1988;62:749.756.

124. Berk, BC; Vekshtein, V; Gordon, HM; Tsuda, T: Angiotensin II-stimulated protein synthesis in cultured vascular smooth muscle cells. Hypertension 1989;13:305-314.

125. Schiffers, PM; Struyker-Boudier, HA; DeMey, JG: Effects of angiotensin II and angiotensin converting enzyme inhibitors on contractile and growth responses in isolated carotid arteries of the rat. Basic Res Cardiol 1991;86(Suppl.1):83-89.

126. Rainer, RS; Eldridge, CS; Gilliland, GK; Naftilan, AJ: Antisense oligonucleotide to cutos blocks the angiotensin II-induced stimulation of protein synthesis in rat antic smooth muscle cells. Hypertension 1990;16:326.

127. Itoh, H; Pratt, RE; Dzau, VI: Antisense oligonucleotides complementary to PDGF in NA attenuate angiotensin II-induced vaseular hypertrophy. Hypertension 1990;16:325.

128. Gibbons, GH; Pratt, RE; Dzau, VJ: Vascular smooth muscle cell hypertrophy vs. hyperplasia. Autocrine transforming growth factor- $\beta 1$ expressin determines growth response to angiotensin II. $\mathbb{C}$ Clin Invest $1992 ; 90: 456-461$.

129. Assoian, RK; Spon, MB: Type beta transforming growth factor in human platelets: release during platelet degranulation and action on vascular smooth muscle cells. I Cell Biol 1986;102:1217-1223.

130. Owens, GK; Geisterfer, AA; Yang, $Y W$, Komoriya, A: Transforming growth factor-betainduced growth inlibition and cellular hypertrophy in cultured vascular smooth muscle cells. J Cell Biol 1988; 107:771-780.

131. Battegay, EJ; Raines, EW; Seifert, RA; Bowen-Pope, DF; Ross, R: ThF-beta induces bimodal proliferation of comective tissue cells via complex control of an autocrine $\mathrm{BDGF}^{2}$ loop. Cell $1990 ; 63: 515-524$.

132. Kato, H; Suzuki, H; Tajima, S; Ogatâ, Y; Tominaga, T; Sato, A; Saruta, T: Angiotensin 11 stimulates collagen symthesis in cultured vascular smooth muscle cells. J Fiypertens 1991:9:17-22. 
133. Scott-Burden, T: Resink, TJ: Hahn, AW: Buhler, FR: Induction of thrombospondin expression in wascular smooth nusele cells by angiotensin $11 . J$ Cardiovasc Pharmacol $1990,36($ Suppl. 7$), 817-520$.

134. Mackie, El; Scoti-Burden, T; Hahn, AW; Kem, F; Bernhardt, J; Regenass, S; Weller, A; Bulter, FR: Expression of tenascin by wascular smooth musele cells. Alterations in hypertensive rats and stimulation by angiotensin II. Am J Pathol 1992;141:377-388.

135. Owens, GK; Schwartz, SM: Vascular smooth muscle cell Inypertrophy and hyperploidy in the Goldblatt Inypertensive rat. Circ Res 1983;53:491-501.

136. Owens, GK: lnfluence of blood pressure on development of aortic medial smooth muscle hypertroplay in spontaneously hypertensive rats. Hypertension $1987 ; 9: 178-187$.

137. Powell, JS; Muller, RK; Rouge, M; Kuhn, H; Hefti, F; Baumgartner, HR: The proliferative response to vascular injury is suppressed by angiotensin-converting enzyme inhibition. JCardiovase Pharmacol 1990; 16(Suppl.4):\$42-\$49.

138. Powell, JS; Clozel, JP; Muller, RK; Kuhn, H; Hefti, F; Hosang, M; Baumgantner, HR: Inhibitors of angiotensin-converting enzyme prevent myointimal proliferation after vascular injury. Science 1989;245;186-188.

139. Osterrieder, W; Muller, RK; Powell, JS; Clozel, JP; Hefti, F; Baumgartner, HR: Role of angiotensin II in injury-induced neointima formation in rats. Hypertension $1991 ; 18$ (Suppl.4):1160-1164.

140. Griffin, SA; Brown, WC; MacPherson, F; McGrath, JC; Wilson, VG; Korsgaard, N: Mulvany, MJ; Lever, AF: Angiotensin II causes vascular hypertrophy in part by a nonpressor mechanism. Hypertension 1991;17:626-635.

141. Johnson, RJ; Alpers, CE; Yoshimura, A; Lombardi, D; Pritzl, P; Floege, J; Schwartz, SM: Renal injury from angiotensin Il-mediated hypertension. Hypertension 1992;19:464-474.

142. Kauffmen, RF; Bean, IS; Zimmerman, KM; Brown, RF; Steinberg, MI: Losartan, a nonpeptide angiotensin II (ANG II) receptor antagonist, inhibits neointima formation following balloon injury to rat carotid arteries. Life Sci 1991:49:223-228.

143. Farthy, RD: Ho, KL; Carretero, OA; Scicli, AG: Kinins mediate the antiproliferative effect of ramipril in at carotid artery. Biochem Biophys Res Commun 1992:182:283-288.

144. Farthy, RD; Carretero, OA; Khang-Loon, H; Scicli, AG: Role of kinins and nitric oxide in the effects of angiotensin converting enzyme inhibitors on neointima formation. Circ Res $1993 ; 72: 1202-1210$

145. Takasaki, 1; Chobanian, AV: Sarzani, R; Brecher, P: Effect of hypertension on fibronectin expression in the rat norta. J Biol Chem 1990;265:21935-21939. 
146. Keeley, FW, Elmoselhi, A; Leenen, FH: Enalapril suppresses nomal accumulation of elastin and collagen in cardiovascular tissues of growing rats. An I Physiol $1992 ; 262: H 1013-H 1021$.

147. Ferrandez, LA; Twickler, J; Mead, A: Neovascularization produced by angiotensin II. J Lab Clin Med 1985;105:141-145.

148. Le-Noble, FA; Hekking, JW; Van-Stratten, HW; Slaaf, DW; Struyker-Boudier, HA: Angiotensin II stimulates angiogenesis in the chorionallantoic membrane of the chick embryo. Eur J Pharmacol 1991;195:305-306.

149. Chiu, AT; Roscoe, WA; McCall, D; Timmermans, PBMWM: Angiotensin II-1 receptors mediate both vasoconstrictor and hypertrophic responses in rat aortic smooth muscle cells. Receptor 1991;1:133-140.

150. Timmermans, PBMWM; Chiu, AT; Herblin, WF; Wong, PC; Smith, RD: Angiotensin II receptor subtypes. Am J Hypertens 1992;5:406-410.

151. Bunkenburg, B; Amelelswoort, T van; Rogg, H; Wood, IM: Receptor-mediated effects of angiotensin 1 il on growth of wascular smooth muscle calls from spontaneously hypertensive rats. Hypertension 1992;20:746\%754.

152. Brown, JJ; Casals-Stenzel, J; Cumming, AMM; Davies, DL; Fraser, F; Lever, AF; Morton, JJ; Semple, PF; Tree, M; Robertson, JIS: Angiotensin II, Aldosierone and Arterial Pressure: A Quantitive Approach. Hypertension 1979;1:159-178.

153. Brown, AJ; Casals-Stenzel, J; Gofford, S; Lever, Af; Morton, JJ: Comparison of fast and slow pressor effects of angiotensin II in the conscious rat. Am J Physiol 1981;241:H381H388.

154. Reid, IA: Interactions between Angll, sympathetic nervous system, and baroreceptor reflexes in regulation of blood pressure. Am J Physiol 1992:262:E763-E778.

155. Bevan, RD: Effect of sympathetic denervation on smooth nuscle cell proliferation in the growing rabbit ear artery. Circ Res $1975 ; 37: 14-19$.

156. Zimmerman, BG: Adrenergic faciliation by angiotensin: does it serve a physiological function. Clin Sci 1981;60:343-348.

157. Zimmerman, BG; Whitmore, L: Effect of angiotensin and phenoxybenxamine in vessels during sympathetic nerve stimulation. Int J Neuropharmacol $1967 ; 6: 27-38$.

158. Starke, K; Werner, U; Schumann, HJ: Wirkung von Angiotensin auf Funktion und Noradrenalinabgabe isolierter Kaninchenherzen im Ruhe und bei sympathicusreizung. Schmiedebergs Archives of Pharmacology 1969;265:170-186.

159. Bewan, JA: Some bases of differences in vascular response to sympathetic activity. Variations on a theme. Circ Res 1979:45:161-171. 
160. Todd, ME; Gowen, B: Arterial wall and smooth muscle cell development in young Wistar rats and the effects of surgical denervation. Circ Res 1991;69:438-446.

161. Blacs, $\mathbb{N}$; Boissel, JP: Growth-stimulating effect of catecholamines on rat aortic smooth muscle cells in culture. J Cell Physiol 1983;116:167-172.

162. Yamori. $Y$; Mano, M; Nara, $Y$; Horie, R: Catecholamine-induced polyploidization in vascular smooth muscle cells. Circulation 1987;75(Suppl.1):192-195.

163. Nakaki, T; Nakayama, M; Yamamoto, S; Kato, R: Alpha l-adrenergic stimulation and beta 2-adrenergic inhibition of DNA synthesis in vascular smooth muscle cells. Mol Pharmacol 1990;37:30-36.

164. Majesky, MW: Daemen, MJ: Schwartz, SM: Alpha 1-adrenergic stimulation of plateletderised growth factor A-chain gene expression in rat aorta. J Biol Chem 1990;265:1082. 1088.

165. Thompson, KE; Friberg, P; Adams, MA: Vasodilators inhibit acute $\alpha_{4}$-adrenergie receptorinduced trophic responses in the vasculature. Hypertension 1992:20:809-815. 
MATERIALS AND METHODS 


\subsection{ANIMALS}

All rats used were obtained from local inbred strains (Central Animal Facilities, University of Limburg). In all but two experiments we used adult male WKY rats weighing $250-300 \mathrm{~g}$ at the start of the experiment. In the experiment described in chapter 3 male Sprague Dawley rats $(300-350 \mathrm{~g})$ were used, whereas in the experiment described in chapter 7 we used 5 weeks old male normotensive Wistar Kyoto rats. Rats were kept at a 12 hour day/night cycle, and were provided with regular food (Hope Farms, Woerden, the Netherlands) and tap water ad libitum. All experiments were performed according to institutional guidelines.

\subsection{SURGERY}

\subsubsection{Aorta and carotid artery injury}

In the experiments described in chapter 6,8 and 9 the left common carotid artery and thoracic aorta were denuded of endothelium according to the method of Baumgartner (1) and modified by Clowes (2). To this end the animals were anesthetized with pentobarbital $\left(60 \mathrm{mg} / \mathrm{ml}\right.$, Veterinary Laboratories Inc.). $\mathrm{A} \mathrm{H}_{2} \mathrm{O}$ filled embolectomy catheter (2F Fogarty, Baxter, Maarsen, the Netherlands) was unserted into the left external carotid artery, and passed down the common carotid artery, through the descending thoracic aorta. Subsequently, the balloon was inflated sufficiently to generate slight resistance, and withdrawn while rotating. This procedure was repeated three times to achieve total endothelial denudation of the thoracic arta and the left common carotid artery. The catheter was removed, the external carotid ligated, and the wound closed. Blood flow was maintained through the common and intemal carotid arteries.

The right carotid arteries were left untraumatized and served as an internal control. In chapter 3 only the thoracic aorta was denuded of endothelium. Therefore the catheter was inserted into the left common carotid artery and passed down into the abdominal aorta. After the denudation procedures were repeated three times, the catheter was removed and the left common carotid artery ligated.

\subsubsection{Implantation of minipumps}

A previously filled osmotic minipump (Alzet models 2001, 2002 or $2 \mathrm{mll}$, Alza Corp. Palo Alto, CA, USA) was inserted subcutaneously between the shoulder blades under ether anesthesia. When drug infusion was continued for 14 days, the pump (Alzet models 2001 and $2 \mathrm{mll}$ ) was replaced after 1 week and a freshly filled new pump was inserted into the same place. 


\subsection{BLOOD PRESSURE MEASUREMENTS}

Blood pressure measurements were taken according to two different methods. The first method was used to obtain dose-response curves of the $\alpha_{1}$-adrenoteceptor antagonists prazosin and doxazosin. Rats were infused during one week with either the $\alpha_{1}$-adrenoreceptor antagonist or $50 \%$ DMSO (vehicle) by subcutaneously implanted minipumps. At the time of blood pressure measurements, rats were anesthesized with pentobarbital (60 $\mathrm{mg} / \mathrm{kg}$ i.p.), and a polyethylene catheter was implanted in the abdominal aorta via the left femoral artery to measure blood pressure. This arterial catheter was connected to a pressure transducer (Statham) and the signals were recorded on a polygraph (model 7D, Grass Instrument Co., Quincy, Massachusetts, USA). A second catheter was introduced in the abdominal vena cava via the right femoral vein for the administration of the agonist. Phenylephrine was administered by continuous infusion. A dose-response curve was obtained with infusions ranging from 0.01 to $100 \mu \mathrm{g} / \mathrm{kg}$ per minute. Infusions were continued until maximal blood pressure responses were achieved and then increased in a step-wise manner. From the logarithmic dose-response curve, the $\mathrm{ED}_{50}$ was calculated as the dose resulting in $50 \%$ of the maximal response.

The second method included the measurement of systolic blood pressure (SBP) by tailcuff plethysmography (Narco Biosystems, Houston, TX, USA) in conscious, slightly restrained animals and was used in the experiments described in chapters 4-8. One week before the start of experiments, the animals were familiarized three times with the manipulations and restraint. Systolic blood pressures were measured 3 times a week; each time the mean of three measurements per animal was used.

\subsection{TISSUE PROCESSING}

At the end of each experiment rats were killed in deep ether anesthesia. Two different protocols were used for tissue processing:

1. The arterial system was perfusion-fixed at a pressure of $100 \mathrm{mmllg}$ for 5 minutes with 10\% phosphate buffered formalin via a catheter placed in the abdominal aorta and the tissues were excised and immersion lixed in the same fixative overnight. The tissues were then routinely processed and embedded in paraffin (Paraplast, Sherwood, Missouri, USA).

2. Tissues were directly excised and further processed for in situ hybridization. For this purpose, freshly isolated tissues were immersed in $4 \%$ paraformaldehyde 0.1 $\mathrm{M}$ sodium phosphate buffer at $\mathrm{pH} 7.4$ at $4^{\circ} \mathrm{C}$ for $1-3 \mathrm{hrs}$. This was followed by immersion in sterile $15 \%$ (weight/volume (wt/vol)) sucrose/isophosphate-buffered saline overnight at $4^{\circ} \mathrm{C}$ to prevent freezing artefacts. The fixed tissues were subsequently placed in O.C.T. embedding medium (O.C.T., Miles Scientilic, Elkhart, Indiana, USA), quickly frozen in liquid nitrogen and stored at $-70^{\circ} \mathrm{C}$. The frozen tissues were sectioned at $7 \mu \mathrm{m}$ using a cryostat and mounted onto micro- 
scopic slides coated with Vectabond (Vector Labs, Burlingame, CA, USA). Sections were stored at $-70^{\circ} \mathrm{C}$ with a desiccant until use.

Besides cryosections, also paraffin sections were used for in situ hybridization. For this purpose isolated tissues were placed directly in $4 \%$ paraformaldehyde, processed and embedded in paraffin. $4 \mu \mathrm{m}$ sections were cut on a microtome and placed on Vectabond coated slides.

\subsection{HISTOLOGY}

\subsubsection{Immunohistochemistry}

Staining with anti-5-bromo-2' deoxyuridine (anti-BrdUrd)

The incorporation of the thymidine analogue, BrdUrd, in SMC cells was visualized by staining with an anti-BrdUrd antibody. Therefore $4 \mu \mathrm{m}$ thick paraffin sections were cut. Sections were deparafinized in xylene and 100\% ethanol, followed by incubation in $0.3 \% \mathrm{H}_{2} \mathrm{O}_{2}$ in methanol to block endogenous peroxidase activity. Sections were then digested in $0.02 \mathrm{mg} / \mathrm{ml}$ pepsin (Sigma, St. Louis, MO, USA) in $0.1 \mathrm{~N} \mathrm{HCl}$ for $30 \mathrm{~min}$ at $37^{\circ} \mathrm{C}$ and subsequently incubated in $1.5 \mathrm{~N} \mathrm{HCl}$ for $15 \mathrm{~min}$ at $37^{\circ} \mathrm{C}$. After rinsing in $0.1 \mathrm{M}$ sodium tetraborate pH 8.5 and TBS (Tris buffer $=$ $0.14 \mathrm{M} \mathrm{NaCl}, 4 \mathrm{mM}$ Tris- $\mathrm{HCl}, \mathrm{pH} 7.4$ ), sections were incubated with a monoclonal anti-BrdUrd antibody $(3,4)$ for one hour at $37^{\circ} \mathrm{C}$, followed by incubation with biotinylated rabbit anti mouse $\operatorname{lgG}$ (Amersham, U.K.) at room temperature (RT) for $30 \mathrm{~min}$. Sections were then labeled for $30 \mathrm{~min}$ (RT) with an avidin/biotinperoxidase complex (Vectastain-ABC kit, Vector Labs, Burlingame, CA, USA) using 3,3'diaminobenzidine as the chromogen. The sections were counterstained with hematoxylin, dehydrated through graded series of alcohols, cleared in xylene and mounted.

After immunostaining (figure 2.1), the number of BrdUrd positive cells and total number of cells in either the media or neointima of each cross-section was counted. Counting was performed without knowledge of the treatment group to which the stained section belonged. The labeling fraction, $\mathrm{LF}(\%)=$ (number of $\mathrm{BrdUrd}$ positive SMC in the media (or neointima) / total number of SMC in the media (or neointimal) $\times 100 \%$, in each cross-section was used as an indicator of SMC DNA synthesis. 


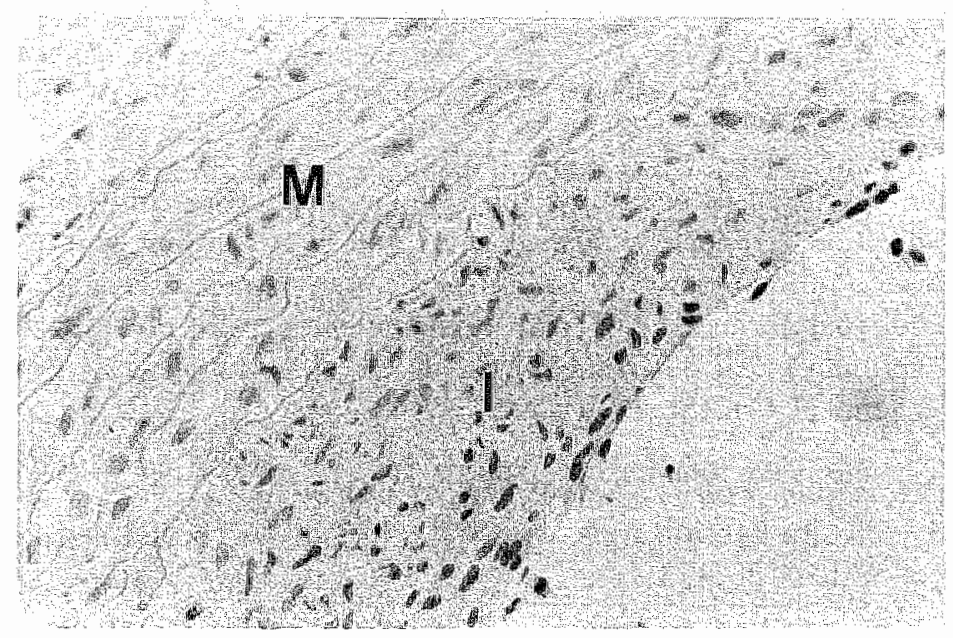

Figure 2.1 Photomicrograph of a cross-section of balloon injured left carotid arteries stuined immunohistochemically for anti-BrdUrd (400X). Abbreviations: $M=$ media; I wintima.

\subsubsection{Morphometry}

\section{Cross-sectional area}

To measure the cross-sectional areas of the vessel media and neointima $4 \mu \mathrm{m}$ cross-sections were stained for elastin with Lawson solution (Boom, Meppel, the Netherlands) for $30 \mathrm{~min}$, and afterwards differentiated in $70 \%$ ethanol. Slides were then rinsed in water and dehydrated in graded series of alcohol, $100 \%$ xyllene and mounted. The cross-sectional areas of the media or neointima were measured using a computerized morphometry system (Quantimet 750, Leica, Cambridge, U.K.) The CSA of the media was defined as the area enclosed within the external and internal elastic lamina, and the CSA of the neointima was defined as the area enclosed within the internal elastic lamina and the lumen.

\section{Determination of elastin and collagen protein content}

Lawson-stained cross-sections were also used to measure the amount of elastin protein. The relative elastin area, i.e the percentage of the total measured area that stained positive for elastin, was determined using the Quantimet 750. Six fields (magnification $400 \mathrm{x}$ ) were measured per cross-section, on one threshold. Idertical procedures were followed for the measurement of collagen protein. $4 \mu \mathrm{m}$ Crosssections were stained for collagen by incubation in $0.2 \%$ (wt/wol) aqueous phosphomolybdic acid during $5 \mathrm{~min}$., followed by an incubation in $0.1 \%$ sirius red 
in saturated picric acid (90 min.). Sections were washed in $0.01 \mathrm{~N} \mathrm{HCl}(2 \mathrm{~min})$, cleared and mounted.

\subsubsection{In situ hybridization}

This technique was used to determine the cellular localization of specific mRNAs. For the hybridization radioactive labeled RNA and DNA probes were used.

Acetic anhydride, formamide, NaCl, ethylenediamine tetra acetic acid (EDTA), Bmercaptoethanol, parafornaldehyde and triethanolamine were obtained from Merck (Darmstadt, Germany). All other chemicals, unless stated otherwise, were obtained from Sigma Chemical Co. (St. Louis, MO, USA).

\section{In situ hybridization with [3J-labeled RNA probes}

The radioactive in situ hybridization with RNA probes was performed according to the protocol of Wilcox et al.(5).

Probes For the preparation of RNA probes CDNA was linearized at the appropriate restriction site (table 2.1 ) with a restriction endonuclease. Single stranded RNA probes complementary to the cellular mRNA (anti-sense) were obtained by run-off transcription (all chemicals supplied by a riboprobe labeling kit, Ribobrobe System II,Promega), $12 \mu \mathrm{M}\left[{ }^{35} \mathrm{~S} J \mathrm{UTP}\right.$ (specific activity, $1000 \mathrm{Ci} / \mathrm{mmol}$, Amersham, U.K.) was evaporated in an eppendorf tube, followed by addition of $40 \mathrm{mM}$ Tris- $\mathrm{HCl} 7.5$, $6 \mathrm{mM} \mathrm{MgCl}$ and $2 \mathrm{mM}$ spermidine, $0.01 \mathrm{M}$ dithiothreitol, 10 units ribonuclease inhibitor, $0.5 \mathrm{mM}$ ATP, $0.5 \mathrm{mM}$ GTP and $0.5 \mathrm{mM}$ CTP, $1 \mu \mathrm{g}$ cDNA template and 10 units of SP-6 or T7 RNA polymerase. The reaction mixture was incubated for 1 hr at $37^{\circ} \mathrm{C}$. Then $1 \mu \mathrm{g}$ of RNAse-free DNAse (Promega) was added to remove the DNA template $\left(15 \mathrm{~min}, 37^{\circ} \mathrm{C}\right)$, followed by extraction with $50 \%$ phenol $48 \%$ chloroform/ $2 \%$ isoamylalcohol (vol/vol/vol), after which the probe was ethanol precipitated.

Prehybridization Prior to hybridization, the slides were pretreated with $4 \%$ paralomaldehyde for 10 min at $4^{\circ} \mathrm{C}$, followed by a proteinase $\mathrm{K}$ incubation ( 5 $\mu \mathrm{g} / \mathrm{ml}$ ) for $10 \mathrm{~min}$ at RT. Sections were then prehybridized for 1 hr in $100 \mu l$ prehybridization buffer ( $50 \%$ (vol/wol) formamide/ $0.3 \mathrm{M}$ NaCl/ $20 \mathrm{mM}$ Tris pH \&/ $5 \mathrm{mM}$ EDTA/ $0.02 \%$ (wt/vol) polyvinvyl-pyrrolidone/ $0.02 \%$ (wt/vol) Ficoll/ $0.02 \%$ (wtwol) bovine serum albumin/ 10\% (wt/vol) dextran sulfate/ $10 \mathrm{mM}$ dithiotreitol at $37^{\circ} \mathrm{C}$.

Mybridization $\left.\right|^{5} \mathrm{~S}$-Labeled probe was added to the prehybridization buffer in a concentration of $600.000 \mathrm{cpm}$ per slide; slides were hybridized at $55^{\circ} \mathrm{C}$ overnight. Atter hybridization the slides were washed in $2 \times \mathrm{SSC}(2 \times \mathrm{SSC}=0.3 \mathrm{M} \mathrm{NaCl}, 30$ $\mathrm{mM}$ sodium citrate, pH 7.0)/ $1 \mathrm{mM}$ EDTA $10 \mathrm{mM}$ B-mercaptoethanol for 10 minutes $(2 \times)$, treated with RNAse $(20 \mu \mathrm{g} / \mathrm{ml})$, washed for 2 hours in $0.1 \times \mathrm{SSC}$ at 
$55^{\circ} \mathrm{C}$, washed in $0.5 \times S S C$ without EDTA/B-mercaptoethanol and dehydrated by immersion in increasing alcohol grades.

\section{In situ hybridization with [35]-labeled DNA probes}

Probes For the preparation of a labeled cDNA probe the CDNA fragments were isolated from the vector with restriction endonucleases and labeled with $\left[{ }^{35} \mathrm{~S}\right] \mathrm{dCTP}$ (specific activity, $1000 \mathrm{Ci} / \mathrm{mmol}$, Amersham) using a random primed labeling kit (Random Primed DNA Labeling Kit, Boehringer Mannheim, Germany). The radiolabeled DNA probe was made using $25 \mathrm{ng}$ denatured DNA template, which was incubated with $0.5 \mathrm{mM} \mathrm{dATP}, 0.5 \mathrm{mM}$ dGTP, $0.5 \mathrm{mM} \mathrm{dTTP},\left[{ }^{35} \mathrm{~S}\right] \mathrm{dCTP}$ and 2 units Klenow enzyme in reaction buffer. The probe was purified by chromatography on a Sephadex G-75 column and ethanol precipitated.

Prehybridization Paraffin sections were deparaffinized, treated with pepsin $(0.5$ $\mathrm{mg} / \mathrm{ml}$ in $0.2 \mathrm{~N} \mathrm{HCl}$ ) for $30 \mathrm{~min}$, placed in $4 \%$ paraformaldehyde for $10 \mathrm{~min}$, rinsed $2 \times 3$ min in phosphate buffered saline (PBS $=0.14 \mathrm{M} \mathrm{NaCl} 2.7 \mathrm{mM} \mathrm{KCl} /$ $\left.1.7 \mathrm{mM} \mathrm{KH}_{2} \mathrm{PO}_{4}, \mathrm{pH} 7.4\right)$. Sections were then incubated in $0.25 \%$ ( $\mathrm{vol} / \mathrm{vol}$ ) acetic anhydride/ $0.1 \mathrm{M}$ triethamolamine $\mathrm{pH} 8.0$ for $10 \mathrm{~min}$, followed by incubation in $50 \%$ formamide/ $2 \times S S C$ at $37^{\circ} \mathrm{C}$ for $10 \mathrm{~min}$. Sections were then prehybridized for one hour in prehybridization buffer (see protocol $\left[{ }^{35} \mathrm{~S}\right]$-labeled RNA probe).

Hybridization Here, the same procedures were followed as for hybridization with RNA probes. After hybridization, the sections were washed in $2 \times S S C / 10 \mathrm{mM} \mathrm{B}$ mercaptoethanol ( $2 \times 10 \mathrm{~min}$ and $1 \times 60 \mathrm{~min}$ at $\mathbb{R T}$ ), followed by washing in $2 \times \mathrm{SSC}$ $\left(3 \times 10 \mathrm{~min}, 37^{\circ} \mathrm{C}\right)$ and in $0.1 \times \mathrm{SSC}\left(3 \times 10 \mathrm{~min}, 37^{\circ} \mathrm{C}\right)$, after which sections were dehydrated.

Autoradiography After dehydration and drying, the slides were dipped in 1:1 water diluted NTB-2 nuclear emulsion (Kodak, Technorama, Zürich, Switzerland) at $42^{\circ} \mathrm{C}$, and exposed at $4^{\circ} \mathrm{C}$ in lightight black boxes, with a desiccant. The exposure time was dependent on message abundance and varied between $1-8$ weeks. The slides were developed with Kodak D19 developer for 4 min at $13-15^{\circ} \mathrm{C}$, fixed in $0.8 \mathrm{M}$ sodium thiosulfate $0.09 \mathrm{M}$ potassium disulfate (Merck) for $8 \mathrm{~min}$ at 13 $15^{\circ} \mathrm{C}$, rinsed in distilled water and counterstained with hematoxylin. Sections were examined by both dark-field and bright-field microscopy. 
Table 2.1 Important characteristics of the CDNA's used for in situ hybridization.

\begin{tabular}{|c|c|c|c|c|c|}
\hline gend & vector & restriction site & size & $\begin{array}{l}\text { paraffin or cryo- } \\
\text { sections }\end{array}$ & reference \\
\hline rat elastin & $\mathrm{pGEM}-4$ & ECoRI & $498 \mathrm{bp}$ & cryosections & $\begin{array}{l}\text { C. Giachelli, Univer- } \\
\text { sity of Washington, } \\
\text { Seatle, WA, USA }\end{array}$ \\
\hline $\begin{array}{l}\text { rat collagen } \\
\alpha_{i}(\mathrm{I})\end{array}$ & PBR322 & BamHL-Pst & $1.3 \mathrm{~kb}$ & paraffin sections & $\begin{array}{l}\text { D. Rowe, University } \\
\text { of Conneticut CN, } \\
\text { USA }\end{array}$ \\
\hline $\begin{array}{l}\text { rat collagen } \\
\alpha_{1} \text { (III) }\end{array}$ & pUCl3 & EcoRI-Xbal & $1.6 \mathrm{~kb}$ & parafin sections & $\begin{array}{l}\text { E. Vuorio, University } \\
\text { of Tampere. Finland }\end{array}$ \\
\hline
\end{tabular}

\subsection{BIOCHEMICAL ASSAYS}

\subsubsection{Plasma catecholamines}

Sampling $2 \mathrm{ml}$ Blood was drawn from non disturbed animals and collected in chilled heparinized tubes containing $12 \mathrm{mg}$ of glutathione. Tubes were centrifuged at 3000 rotations per minute at $4^{\circ} \mathrm{C}$ for 15 min and plasma was stored at $-20^{\circ} \mathrm{C}$ until use.

Detection Plasma catecholamines (norepinephrine and epinephrine) were determined (Dept. of Pharmacology, Maastricht) by high performance liquid chromatography (HPLC) with fluorometric detection according to the method of Van der Hoorn (6). Briefly, the catecholamines were extracted from the plasma samples by liquid-liquid extraction: a-methylnorepinephrine (Sigma), $2 \mathrm{M}$ ammonia-ammonium chloride butfer pH 8.6 (Merck) and n-haptene (J.T. Baker, Deventer, the Netherlands) were added to the plasma. After shaking and centrifugation the organic phase was separated from the aqueous layer. To the organic phase $0.01 \mathrm{M}$ hydrochloric acid (Merck), l-octanol (Merck) and $0.08 \mathrm{M}$ acetic acid (Merck) wene added, shaken and centrifuged, and again the aqueous layer was separated from the organic phase. This whole procedure was repeated wice.

Acetonitrile (Fisons, Loughborough, U.K.) was added to the concentrate collected by the extraction procedure, together with $1.75 \mathrm{M}$ bicine pH 7.05 (Sigma) and the Muorescent agent 1,2-diphenylethylenediamine (DPE, Sigma). The derivation reaction was started by addition of potassium ferticyamide (Janssen, Beerse, Belgium).

Chromatography was performed by injection of $100 \mu$ of each concentrate in the HPLC with a spherisorb 5 ODS-2 column (150 mm x $4.6 \mathrm{~mm}$. Chrompack, Middelburg, The Netherlands). Fluorescent derivatives were monitored at an axcitation wavelength of $350 \mathrm{~mm}$ and an emission wave length of $480 \mathrm{~nm}$. The internal standard was a-methylnorepinephrine (Sigma). 


\subsubsection{Tissue elastin and collagen}

Thoracic aorta and carotid arteries were isolated, washed free of blood and cleared of adhering tissues. A microscope and fine forceps were used to separate the media from the adventitia. Both elastin and collagen could be measured from the same material as described and outlined in figure 2.2 .

The amount of elastin was determined by the method of Keeley (7) and TodorovichHunter(8). Tissues were rinsed in $0.9 \% \mathrm{NaCl}$. To each tube preheated $0.01 \mathrm{M}$ phosphate buffer containing $1 \%$ (wt/vol) sodium dodecyl sulphate (SDS), pH 7.0, was added and this was heated for $15 \mathrm{~min}$ at $100^{\circ} \mathrm{C}$. Further extraction took place overnight at $20^{\circ} \mathrm{C}$. The SDS extract was saved for collagen determination, while the SDS residue was digested with cyanogen bromide $(\mathrm{CNBr}, 50 \mathrm{mg} / \mathrm{ml}$ in $70 \%$ formic acid) at $20^{\circ} \mathrm{C}$ for 24 hrs.

The amount of tissue elastin and the amount of tissue collagen were measured by quantitation of the amount of hydroxyproline in respectively the $\mathrm{CNBr}$ residue (elastin), and the SDS extracts and $\mathrm{CNBr}$ extracts (total collagen) according to the method of Chiariello (9).

The tissue was dried and weighed, transferred into eppendorf tubes with screw caps. $200 \mu \mathrm{l} 6 \mathrm{~N} \mathrm{HCl}$ was added and hydrolysis took place for $16 \mathrm{hrs}$ at $105^{\circ} \mathrm{C}$. The samples were dried under vacuum and the residues were reconstituted in $200 \mathrm{ktl}$ double distilled $\mathrm{H}_{2} \mathrm{O} .5-100 \mu \mathrm{l}$ of each sample was taken and the volume was adjusted to $100 \mu \mathrm{l}$ with distilled $\mathrm{H}_{2} \mathrm{O}$. Subsequently, $300 \mu \mathrm{l}$ of acetate-citrate-isopropanol buffer $(0.7 \mathrm{M}$ sodium acetate/ $0.2 \mathrm{M}$ trisodium citrate/ $45 \mathrm{mM}$ citric acid in isopropanol, $6: 4(\mathrm{vol} / \mathrm{vol})$ ) was added, and $100 \mu \mathrm{l}$ oxidant solution $(84.5 \mathrm{mg}$ chloramine $\mathrm{T} / \mathrm{ml}$ buffer), and incubated during $5 \mathrm{~min}$ at $25^{\circ} \mathrm{C}$. The oxidation of hydroxyproline results in the formation of a pyrrole, which reacts with $\mathrm{p}$ dimethylaminobenzaldehyde $(1.3 \mathrm{ml} 3.5 \mathrm{M}$ p-dimethylaminobenzaldehyde is added to $72 \%(\mathrm{w} / \mathrm{v})$ perchloric acid and incubated during $30 \mathrm{~min}$ at $65^{\circ} \mathrm{C}$ ) to form a coloured compound. After cooling absorbance was measured at $558 \mathrm{~nm}$ against a blank (acetate-citrate-isopropanol buffer) sample. Calculation was performed by means of a calibration curve. 


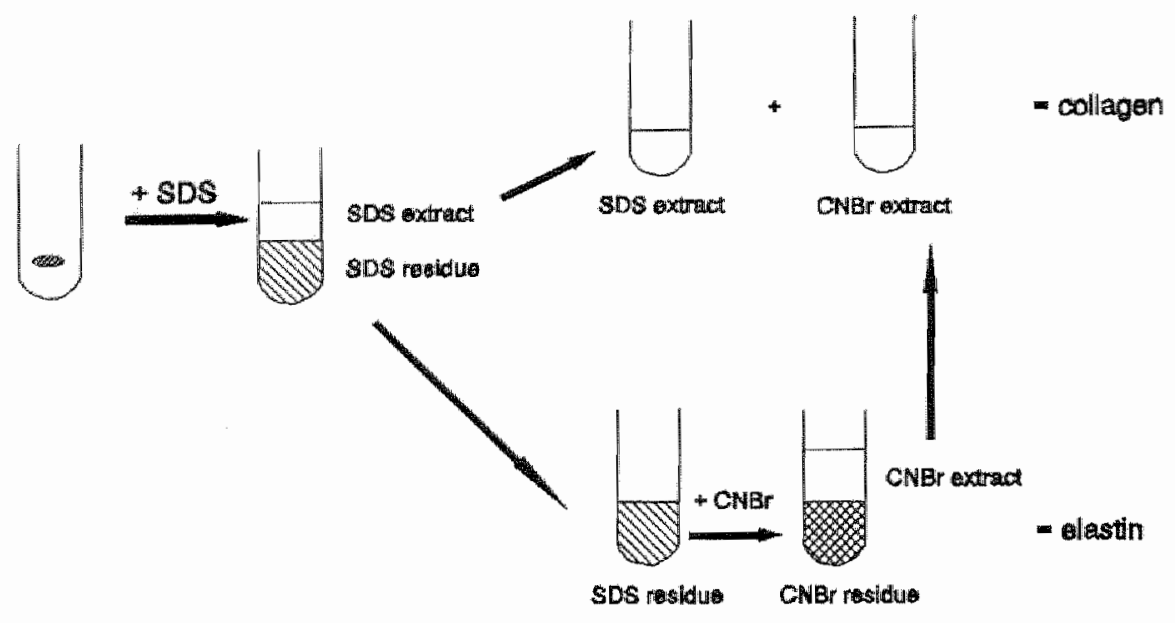

Figure 2.2 Schematic drawing of the biochemical determination of tissue collagen and tissue elastin from the same material (CNBr = cyanogen bromide; SDS = sodium dodecyl sulphate).

\subsection{STATISTICS}

Comparisons between groups for heart weight, BrdUrd labeling traction and CSA were made by one way analysis of variance (ANOVA). Comparisons between groups for body weight and blood pressure were made by two way ANOVA. ANOVA was followed by Bonferroni's t-test if differences existed between the groups (10). Data are expressed as mean \pm SEM; differences are regarded as statistically significant if $\mathrm{p}<0.05$. 


\section{REFERENCES}

1. Baungartner, H-R: Eine neue Methode zur Erzeugung von Thromben durch gezielte Überdehnung der Gefaswänd. Z ges exp Med 1963;137:227.247.

2. Clowes, AW; Reidy, MA; Clowes, MM: Kinetics of cellular proliferation after arterial injury. I. Smooth muscle growth in the absence of endothelium. Lab lnvest 1983;49:327-333.

3. Gratzner, HG: Monoclonal antibody to 5-bromo- and 5-iododeoxyuridine: an new reagent for detection of DNA replication. Science 1982;218:474-475.

4. Schutte, B; Reynders, MM; Bosman, FT; Blijham, GH: Effect of tissue fixation on antibromodeoxyuridine immunohistochemistry. J Histochem Cytochem $1987,35: 1343-1345$.

5. Wilcox, IN; Smith, KM; Williams, LT; Schwartz, SM; Gordon, D: Platelet-derived growth factor $m R N A$ detection in human atherosclerotic plaques by in situ hybridization. J Clin Invest $1988 ; 82: 1134-1143$.

6. Hoorn, van der FAJ; Boomsma, F; Man in 't Veld, AJ; Schalekamp, MADH: Determination of catecholamines in human plasma by high-performance liguid chromatography: comparison between a new method with fluorescence detection and an established method with electrochemical detection. J Chromatogr 1989;487:17-28.

7. Keeley, FW; Alatawi, A: Response of aortic elastin synthesis and accumulation to developing hypertension and the inhibitory effect of colchicine on this response. Lab Invest 1991;64:499507.

8. Todorovich-Hunter, L; Johnson, DJ; Ranger, P; Keeley, FW; Rabinovitch, M: Altered ellastin and collagen synthesis associated with progressive pulmonary hypertension induced by monocrotaline. Lab Invest 1988;58:184-195.

9. Chiariello, M; Ambrosio, G; Cappelli-Bigazzi, M; Perrone-Filardi, P; Brigante, F; Sifola, $C$; A biochemical method for the quantitation of myocardial scarring after experimental coronary artery occlusion. J Mol Cell Cardiol 1986;18:283-290.

10. Wallenstein, $S$; Zucker, $\mathrm{C}$; Fleiss, $\mathrm{F}$ : Some statistical methods useful in circulation research. Cinc Res 1980;47:1.9. 

COMPARISON OF THE DETERMINATION OF DNA SYNTHESIS BY ['H]THYMIDINE AND 5-BROMO-2'-DEOXYURIDINE IN THE BALLOON INIURED RAT THORACIC AORTA 


\section{SUMMARY}

The labeling of DNA synthesizing smooth muscle cells (SMC) with tritiated thymidine ( $\left.{ }^{3} H J T d R\right)$ is an established method to measure vascular smooth muscle cell DNA synthesis in experimental models of atherosclerosis and hypertension. In this study an alternative labeling method with 5'-bromo-2'-deoxyuridine (BrdUrd) was validated by comparing the number of [ ${ }^{3} H J T d R$ labeled SMC nuclei with the number of BrdUrd labeled SMC nuclei in the same cross-section of rat thoracic aorta. Therefore, both BrdUrd and PHJTdR were continuously infused immediately after balloon injury of the rat thoracic aorta, and the labeling fraction was estimated 4 days after injury. 80\% of the total number of labeled SMC were both BrdUrd and [3I]TaR positive. Comparable levels of single-labeled [3H]TdR labeled and single-labeled BrdUrd SMC were found. The data indicate that the BrdUrd labeling of SMC is a valid alternative method for the classic PHJTdR labeling of SMC.

\section{INTRODUCTHON}

In the last decade several laboratories have identified increased DNA synthesis of vascular smooth muscle cells as a key process in experimental models of hypertensive vascular disease and restenosis after vascular injury $(1,2)$. Different methods are available to measure the accelerated smooth muscle cell DNA synthesis. Since the 1950 s the most established technique to measure DNA synthesis is the tritiated thymidine $\left.{ }^{3} \mathrm{H}\right] \mathrm{TdR}$ labeling technique (3). This method has not only been used to study cell kinetics in vitro, but also to study the kinetics of the vascular response to balloon injury in vivo (4-7). The method is based on the incorporation of radiolabeled thymidine during the S-phase of the cell cycle, but has several disadvantages: it involves the use of radioactivity, it is laborious and lime consuming and the detection of positive labeled nuclei may be difficult because of relative high background labeling.

To date several alternative methods for the determination of DNA synthesis in vivo are available, including the incorporation of the thymidine anallogue 5'-bromo-2'-deoxyuridine (BrdUrd) (8). BrdUrd can be detected immunohistochemically using a highly specific monoclonal antibody (8). This immunohistochemical technique offers several advantages: it is non radioactive, the detection of labeled nuclei is faster, the resolution of labeled nuclei is higher and the technique is cheaper.

The current in vivo study is a methodological one and was set up to validate the BrdUrd labeling technique by comparing it with the $\left[{ }^{3} \mathrm{H}\right] \mathrm{TdR}$ labeling of DNA synthesing vascular smooth muscle cells (SMC). In order to achieve increased SMC DNA synthesis, and therefore increased incorporation of the labels, the 
thoracic aorta of male adult rats was injured by an inflated balloon. Comparison of the two labeling techniques was achiewed by dual labeling. Theretore animals received both labels [ $\left.{ }^{3} H\right] T d R$ and BrdUrd during four days by two separate osmotic minipumps immediately after injury. To test possible toxic effects, BrdUrd $(50 \mathrm{mg} / \mathrm{ml})$ was administered at two different infusion rates, $1 \mu \mathrm{l} / \mathrm{hr}$, and $10 \mu \mathrm{h} / \mathrm{hr}$ respectively.

Double-labeled SMC formed $80 \%$ of the total number of labeled SMC, indicating a high similarity in the tracing of DNA synthesizing SMC by the [ $\left.{ }^{3} \mathrm{H}\right] \mathrm{TdR}$ and BrdUrd labeling methods. Also, the fraction of single-labeled SMC was identical. The co-infusion of BrdUrd did not affect the ["H]TdR labeling fraction since the $[\mathrm{H}] T \mathrm{TR}$ labeling fraction in the animals receiving dual infusion was not different from the $\left[{ }^{3}\right.$ H]TdR labeling fraction in balloon injured animals that received MT]TR only.

\section{MATERLALS AND METHODS}

15 Male Sprague Dawley rats, obtained from Tyler (Seattle, WA), were used. The rats were 3.5 months $(375-400 \mathrm{~g})$ at the start of the experiment. At the start of the experiment, the thoracic aorta was injured by an inflated balloon (chapter 2.2.1). Immediately after surgery osmotic minipumps were implanted, that infused the labels continuously during 4 days. On day 4 , animals were sacrificed and the thoracic aorta was excised.

\section{Labeling of DNA synthesizing cells}

Immediately after surgery, when the rats were still anesthetized, they were randomly divided into 3 groups, $A, B$ and $C(n=5)$. Animals in group $A$ only received [H]TdR (10 $\mathrm{mCi} / \mathrm{ml}$; specific activity $6.7 \mathrm{Ci} / \mathrm{mmole}$; New England Nuclear, Boston, MA) via an intraperitoneally (i.p.) implanted osmotic minipump (Alzet model 2001, infusion rate I $\mu / /$ h). Animals in group $B$ also received $\left[{ }^{3} H\right] T d R$ via an i.p. implanted minipump as well as a second osmotic minipump (Alzet model $200 \mathrm{l}$ ) containing $50 \mathrm{mg} / \mathrm{mll}$ BrdUrd. This latter minipump was implanted subcutaneously between the shoulder blades and delivered BrdUrd at a rate of $3 \mathrm{mg} / \mathrm{kg} / \mathrm{day}$. Animals in group $\mathrm{C}$ also received two osmotic minipumps: one was implanted i.p., and was filled with $1 \mathrm{H}$ thymidine $(10 \mathrm{mCi} / \mathrm{ml}$; Alzet model 2001), the second one (Alzet model $2 \mathrm{mll}$ ) was implanted s.c. and delivered BrdUrd $(50 \mathrm{mg} / \mathrm{ml})$ at a high infusion rate of $10 \mu / / \mathrm{h}(30 \mathrm{mg} / \mathrm{kg} / \mathrm{day})$.

All rats were sacrificed 4 days after balloon injury. The rats were killed by ether overdose and the thoracic aortas were removed. A 1-2 mm segment of thoracic 
aorta was cut between the branches of the third and fourth pair of intercostal arteries, fixed in Camoy's fixative ( $25 \%$ glacial acetic acid/75\% methanol, $v / v)$ overnight, routinely processed and paraffin embedded (chapter 2.4).

\section{BrdUrd immunohistochemistry and autoradiography}

$4 \mu \mathrm{m}$ Cross-sections were cut and stained immunohistochemically with antiBrdUrd using an indirect enzyme-labeled antibody technique as described in chapter 2.5.1.

After staining with 3,3'diaminobenzidine, slides were dehydrated and dipped in Kodak NTB-2 emulsion, which was diluted 1:1 (vol/wol) with distilled water. After 3 weeks exposure in the dark at $4^{\circ} \mathrm{C}$, the slides were developed and lightly counterstained with hematoxylin (chapter 2.5.3).

\section{Counting}

Nuclei counted with more than four grains were regarded positive for incorporation of $\left[{ }^{3} H\right] T d R$. Nuclei were regarded BrdUrd positive when the whole nucleus showed a dense brown staining. BrdUrd and $\left[{ }^{3} \mathrm{H}\right] \mathrm{TdR}$ positively labeled nuclei were counted ( 3 cross-sections per animal) and assigned to one of three groups: 1 . BrdUrd and $\left[{ }^{3} H\right] T d R$ positive nuclei, 2. only BrdUrd positive, and 3. only [ $\left.{ }^{3} \mathrm{H}\right] T d R$ positive. Three different labeling fractions were determined. The first one is an absolute labeling fraction and is calculated by dividing the number of labeled nuclei $\left({ }^{3} \mathrm{H}\right] \mathrm{TdR}$ and/or BrdUrd) and the total number of nuclei in the media of the cross section (\% of total). The second and third labeling fraction are relative labeling fractions and are represented by the number of either $\left.{ }^{3} \mathrm{H}\right] \mathrm{T}$ TR labeled nuclei or BrdUrd labeled nuclei divided by the total number of labeled nuclei (\% of positive).

\section{RESULTS}

Table 3.1 gives the absolute labeling fractions, which are the percentages of double-labeled (labeled with both $\left[{ }^{3} \mathrm{H}\right] \mathrm{TdR}$ and BrdUrd) or single-labeled nuclei (only labeled with $\left[{ }^{3} \mathrm{H}\right] \Gamma \mathrm{TR}$ or BrdUrd) as a fraction of all nuclei present in the media. In group $\mathrm{A}$, the group that received $\left[{ }^{3} \mathrm{H}\right] \mathrm{TdR}$ alone, $6.6 \pm 0.8 \%$ of all nuclei in the media were labeled with $\left[{ }^{3} H\right] T d R$. In groups $B$ and $C$ both $\left[{ }^{3} \mathrm{H}\right] \mathrm{TdR}$ and BrdUrd were administered. In group B, $7.3 \pm 1.3 \%$ of all nuclei in the media of the thoracic aorta were positively labeled with either one or both the labels. In group $\mathrm{C}$, that received a higher dose of Brdurd than group $\mathrm{B}$, the absolute labeling fraction was $5.9 \pm 0.7 \%$. These labeling fractions were not different between groups $A, B$ and $C$. 
Chapter 3

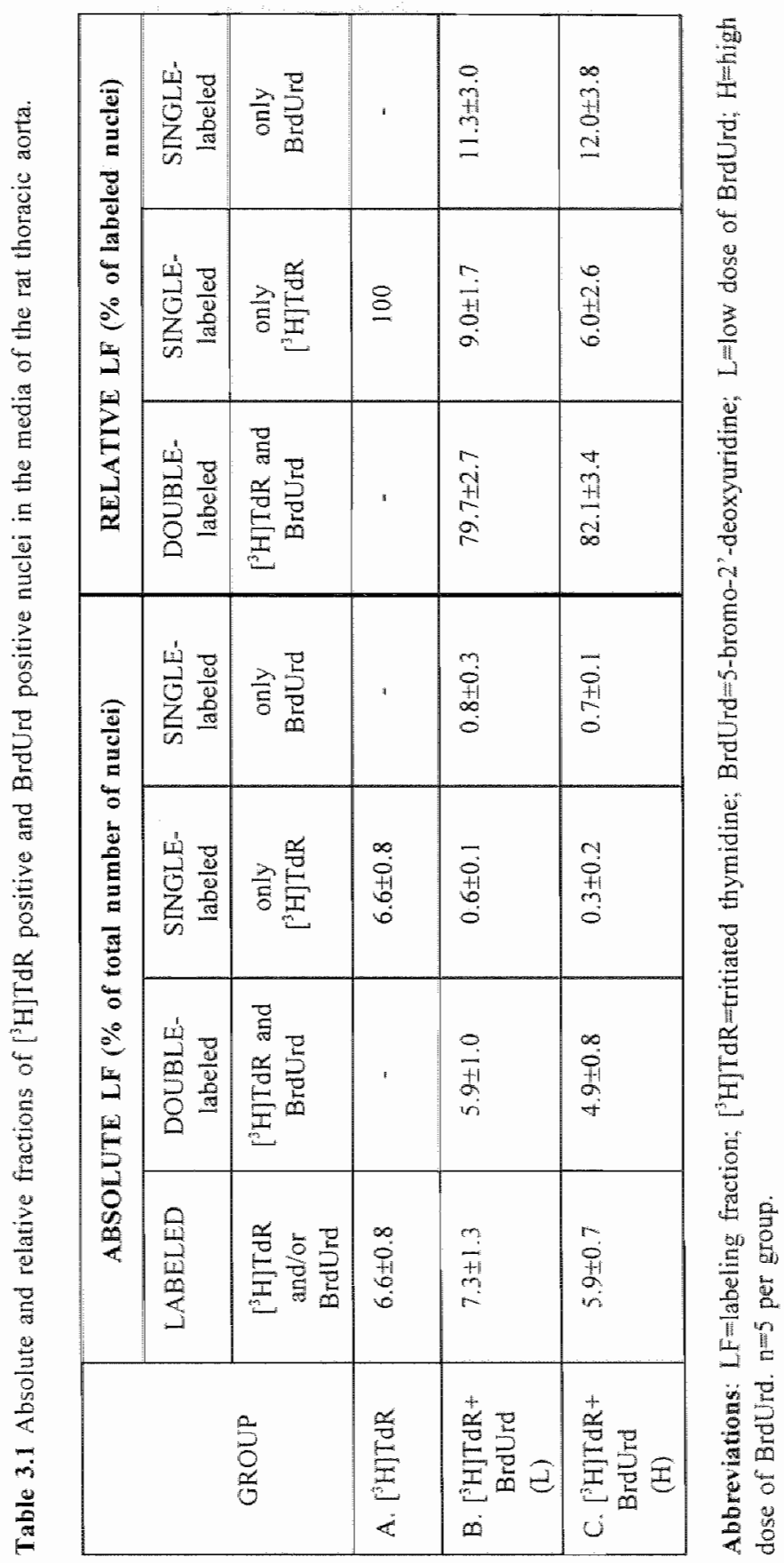


In group B, $5.9 \pm 1.0 \%$ of the total number of nuclei were both $\left[{ }^{3} \mathrm{H}\right] \mathrm{TdR}$ and BrdUrd positive, whereas this fraction was $4.9 \pm 0.8 \%$ in group C. Small fractions of nuclei were only positive for $\left[{ }^{3} H\right] T d R$ or BrdUrd. These single-labeled fractions of either label were not different between groups $B$ and $C$, nor did the fraction of singlelabeled $\left[{ }^{3} \mathrm{H}\right] \mathrm{TdR}$ labeled nuclei differ from the fraction of single-labeled BrdUrd nuclei in both groups.

The relative labeling fractions were defined as the number labeled SMC divided by the total number of positively labeled smooth muscle cells. The data show that in both groups $B$ and $C$, about $80 \%$ of the positive cells were double-labeled with

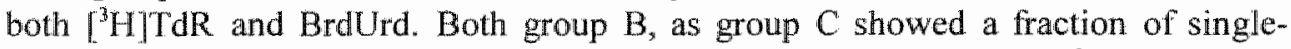
labeled BrdUrd cells equal to the fraction of single-labeled $\left[{ }^{3} \mathrm{H}\right] \mathrm{TdR}$ cells (11.3 $3.0 \%$ vs $9.0 \pm 1.7 \%$ in group $B$ ). Between groups $\mathrm{B}$ and $\mathrm{C}$ no differences were found in the fractions of single-labeled BrdUrd cells $(11.3 \pm 3.0 \%$ vs. $12.0 \pm 3.8 \%$, nor of the single-labeled $\left[{ }^{3} \mathrm{H}\right] \mathrm{TdR}$ cells $(9.0 \pm 1.7 \%$ vs. $6.0 \pm 2.6 \%)$.

\section{DISCUSSION}

In the present study we compared the incorporation of continuously infused $\left[{ }^{3} \mathrm{H}\right] \mathrm{TdR}$ and BrdUrd in the same animal and showed that BrdUrd labeling and subsequent immunohistochemical detection of DNA synthesizing SMC corresponds with the [ [3]TdR labeling method.

Several other investigators have compared BrdUrd labeling with $\left[{ }^{3} \mathrm{H}\right] \mathrm{T} d \mathrm{R}$ labeling both in vivo and in vitro and have found similar results. Simultaneous in vivo administration of BrdUrd and $\left.{ }_{[}^{3} \mathrm{H}\right] \mathrm{TdR}$ labeled mice macrophages equeally sensitive and specific (9). Also, administration of BrdUrd to various cell types and organ segments in vitro labeled the same percentage of cells as $\left[{ }^{3} \mathrm{H}\right] \mathrm{TdR}(9,10)$. The incorporation of BrdUrd and $\left[{ }^{3} \mathrm{H}\right] \mathrm{TdR}$ has also been compared in vascular SMC (11). In both rat aortic SMC in culture and in vivo studies of balloon injured rat aorta repetitive injections with either $0.5 \mathrm{mCi} / \mathrm{kg}\left[{ }^{3} \mathrm{H}\right]$ thymidine or $30 \mathrm{mg} / \mathrm{kg}$ BrdUrd. resulted in an equal labeling fraction. In the present study comparable results were obtained using continuous administration of the two substances.

One of the possible problems with the use of BrdUrd is its potential toxicity. In rats, orally administered doses ranging from as high as 160 to $688 \mathrm{mg} / \mathrm{kg} / \mathrm{day}$ for 28 days did not result in hematological and gastrointestinal toxicicity (12). We used BrdUrd doses of 3 and $30 \mathrm{mg} / \mathrm{kg} /$ day in the present study. The highest dose did not affect the labeling of $\left.{ }^{3} \mathrm{H}\right] \mathrm{TdR}$, indicating that BrdUrd is not toxic at this dose. Furthermore, the present study shows that even $10 \%$ of the $30 \mathrm{mg} / \mathrm{kg} / \mathrm{day}$ dose is enough to label and detect DNA synthesising nuclei. 
Bromo-2'-deoxyuridine is not the only alternative for $\left[{ }^{3} \mathrm{H}\right]$ thymidine; in recent years several cell cycle dependent molecules have been identified that can be used as markers of DNA synthesis. One of these markers is the proliferating cell nuclear antigen (PCNA/cyclin) $(11,13,14)$. PCNA expression has also been compared to the $\left[{ }^{3} \mathrm{H}\right] \mathrm{TdR}$ in the balloon injured rat (11). In that study a consistent higher percentage of PCNA labeling was reported. Differences in PCNA labeling and $\left[{ }^{3} \mathrm{H}\right] \mathrm{TdR}$ labeling (15), BrdUrd labeling (13) or with the S-phase fraction as calculated from flow cytometry (16) have also been described by others. The higher PCNA labeling index is explained by the longer expression of the protein during the cell cycle. Whereas $\left.{ }^{3} H\right] T d R$ and BrdUrd only incorporate into the DNA during the S-phase of the cell cycle, PCNA is expressed not only during the Sphase but also during the $G_{1}$ and $G_{2}$ phase of the cell cycle (13).

An other alternative cell cycle marker $\mathrm{Ki}-67$ is expressed throughout the cell cycle, and not in the $\mathrm{G}_{0}$ phase $(17,18)$. The incorporation of BrdUrd has also been compared to the labeling with the $\mathrm{Ki}-67$ antibody and BrdUrd positive cells were found to form an inclusive subpopulation of the $\mathrm{Ki}-67$ positive cells in 4 different cell lines tested (13).

Although our data as well as the data from other laboratories indicate that BrdUrd may provide information on the amount of DNA synthesis vascular smooth muscle cells the method has its limitations. For instance, the incorporation of BrdUrd or $\left[{ }^{3} \mathrm{H}\right] \mathrm{TdR}$ does not tell us whether the increased DNA synthesis results in nuclear and/or cellular division. Furthermore it cannot be discriminated whether the DNA synthetic activity in nuclei is coupled with nuclear hyperplasia, hyperploidy or DNA repair. To obtain this information additional approaches are necessary, like cell number counting, flow cytometry, measurement of the DNA content of the tissue (19), or stereologic analysis of the cell number (20).

In conclusion, the data indicate that BrdUrd labeling of proliferating SMC can be well compared with the $\left[{ }^{3} \mathrm{H}\right] \mathrm{TdR}$ labeling method. The advantages of the former method are obvious: BrdUrd labeling is non-radioactive, cheaper and faster method to measure DNA synthesis and only very low doses, non-toxic doses of BrdUrd are necessary to label the newly synthesised DNA. 


\section{REFERENCES}

1. Gordon, D; Reidy, MA; Benditt, EP; Schwartz, SM: Cell proliferation in human coronary arteries. Proc Nall Acad Sci USA 1990;87:4600-4604.

2. Ross, R: The pathogenesis of atherosclerosis-an update. N Engl J Med 1986:314:488-500.

3. Hall, PA; Levison, DA: Review: assessment of cell proliferation in histological material. If Clin Pathol 1990;43:184-192.

4. Clowes, AW, Reidy, MA; Clowes, MM: Kinetics of cellular proliferation after arterial injury. 1. Smooth muscle growth in the absence of endothelium. Lab Invest 1983;49:327333.

5. Clowes, $\mathrm{AW}$; Schwartz, SM: Significance of quiescent smooth muscle migration in the injured rat carotid artery. Circ Res 1985;56:139-145.

6. Clowes, AW; Clowes, MM; Reidy, MA: Kinetics of cellular proliferation after anterial injury. III. Endothelial and smooth muscle growth in chronically denuded wessels. Lab Invest $1986 ; 54: 295-303$.

7. Clowes, AW; Clowes, MM; Fingerle, J; Reidy, MA: Regulation of smooth muscle cell growth in injured artery. J Carcliovase Pharmacol 1989;14 Suppl 6:S12-S15.

8. Gratzner, HG: Monoclonal antibody to 5-bromo- and 5-iododeoxyuridine: a new reagent for detection of DNA replication. Science $1982 ; 218: 474-475$.

9. Van-Furth, $\mathrm{R}$ : Van-Zwet, TL: Immunocytochemical detection of 5-bromo-2-deoxyuridine incorporation in individual cells. J Immunol Methods 1988; 108:45-51.

10. Morstyn, G; Pyke, K; Gardner, J; Ashcroft, R; de-Fazio, A; Bhathal, P: Immunohistochemical dentincation of proliferating cells in organ culture using bromodeoxyuridine and a monoclond antibody. J Histochen Cytochem 1986;34:697-701.

11. Zeymer, U; Fishbein, MC; Forrester, IS; Cercek, B: Proliferating cell nuclear antigen inmunohistochemistry in rat aorta after balloon denudation. Comparison with thymidine and bromodeoxyuridine labeling. Am J Pathol 1992;141;685-690.

12. Phuphaich, S; Levin, VA: Bioavailability of bromodeoxyuridine in dogs and toxicity in rats. Cancer Res 1985:45:2387-2389.

13. Coltrera, MD; Gown, AM: PCNA/Cyclin expression and BrdU uptake define different subpopulations in different cell lines. J Histochem Cytochem 1991;39:23-30.

14. van-Dierendonck, JH; Wajsman, JH; Keijzer, R; van-de-Velde, CJ; Comelisse, CJ: Cellcycle-related staining pattems of anti-proliferating cell nuclear antigen monoclonal antibodies. Comparison with BrdUrd labeling and Ki-67 staining. Am J Pathol 1991;138:11651172 . 
15. Galand, P; Degmef, $\mathrm{C}$. Cyclin/PCNA immunostaining as an allemative to tritiated thymidine pulse labelling for marking $S$ phase cells in paraffin sections from animal and human tissues. Cell Tissue Kinet 1989:22:383-392.

16. Garcia, RL; Coltrera, MD; Gown, AM: Analysis of proliterative grade using antiPCNA/cyclin monoclonal antibodies in fixed, embedded tissues. Comparison with flow cytometric analysis. Am J Pathol 1989;134:733-739.

17. Gerdes, J; Schwab, U; Lemke, H; Stein, H: Production of a mouse monoclonal antibody reactive with a human nuclear antigen associated with cell proliferation. Int I Cancer $1983 ; 31: 13-20$.

18. Gerdes, J; Lemke, H; Baisch, H; Wacker, HH; Schwab, U; Stein, H: Cell cycle analysis of a cell proliferation-associated human nuclear antigen defined by the monoclonal antibody Kin67. J Immunol 1984;133;1710-1715.

19. Murat, J-C; Gamet, Li; Cazenave, Y; Trocheris, V: Questions about the use of $[3 \mathrm{H}]$ thymidine incorporation as a reliable method to estimate cell proliferation rate. Biochem J 1990:270:563-564.

20. Mulvany, MJ; Baandrup, U; Gundersen, HJG: Evidence for hyperplasia in mesenterio resistance vessels of spontaneously hypertensive rats using a three-dimensional disector. Circ Res 1985;57:794-800. 

REDUCTION OF THE ANGIOTENSIN II INDUCED VASCULAR SMOOTH MUSCLE CELL DNA SYNTHESIS IN THE RAT THORACIC AORTA BY ALPHA ONE ADRENOCEPTOR BLOCKADE 


\section{SUMMARY}

We explored the effects of $\alpha_{1}$-adrenoreceptor blockade with prazosin on the increased vascular smooth muscle cell DNA synthesis induced by angiotensin II (AngII) in the rat thoracic aorta. Angll was infused with ar without prazosin or its solvent. Observations were compared to those in rats receiving saline or solvent. AngII was infused for 2 weeks by subcutaneously implanted osmotic minipumps at a rate of $0.5 \mathrm{mg} / \mathrm{kg} / \mathrm{day}$. Rals received: $0.9 \% \mathrm{NaCl}$ (the solvent of AngII), AngIl, Angll and $50 \%$ DMSO (the solvent of prazosin), Angll logether with the $\alpha$-adrenoreceptor antagonist prazosin $(5 \mathrm{mg} / \mathrm{kg}$ day), or $50 \%$ DMSO. All animals were infused with 5-bromo-2 -deoxyuridine for two weeks via separate minipumps to measure DNA synthesis. AngII significantly increased the fraction of DNA synthesizing smooth muscle cells (SMC) in the media of the thoracic aorta from $0.4 \pm 0.1 \%$ in the $\mathrm{NaCl}$ group to $10.8 \pm 2.7 \%$ in the Angll group $(n=8)$. DMSO infusion did not affect the AngII induced SMC DNA synthesis, since the labeling fraction in the AngII+DMSO group $(n=4)$ was $10.9 \pm 2.5 \%$. Addition of prazosin to Angll reduced the labeling fraction of SMC to $3.0 \pm 0.7 \%(n=9)$. The remaining $S M C$ DNA synthesis in the prazosin treated group was probably due to the effects of the solvent of prazosin. i.e. $50 \%$ DMSO, since infusion of DMSO alone increased the labeling fraction to $4.1 \pm 0.8 \%(n=6)$. Both systolic blood pressures and medial cross-sectional areas increased during Angll infusion, but these parameters were not altered by prazosin or DMSO. We conclude that $\alpha_{f}$-adrenoreceptors are involved in the AngII induced increase of medial smooth muscle cell DNA synthesis in the rat.

\section{INTRODUCTION}

There is considerable interest in control mechanisms of accelerated smooth muscle cell (SMC) DNA synthesis as a critical event in the pathogenesis of hypertension and restenosis $(1-3)$. While most attention has been devoted to polypeptide growth factors as initiators of this response, recent studies indicate that endogenous regulators of arterial blood pressure, including angiotensin II (Angll) may be involved in the regulation of vascular SMC DNA synthesis (4-6).

Evidence that Angll increases vascular smooth muscle cell DNA synthesis in vivo includes effects of inhibitors as well as agonists. The thoracic aorta of the Goldblatt, 2 kidney 1 clip hypertensive rat, an Angll dependent model of hypertension, shows an increase in the frequency of polyploid smooth muscle cells, suggesting that elevation of Angll may cause SMC DNA synthesis (7). Inhibition of the formation of Angll prevents the development of a neointima after balloon injury in the rat (5). A recent study from our laboratories shows that continuous infusion of Angll stimulates DNA synthesis in both medial and neointimal vascular SMC (6). 
These in vivo studies obviously cannot distinguish between direct and indirect effects of the peptide.

In vitro, Angll does induce a marked increase in cellular protein synthesis of trat aortic smooth muscle cells, but it does not induce proliferation (7-9). Therefore an indirect effect, rather than a direct effect of AngIl on vascular SMC DNA synthesis was suggested. AngIL is found to interact with the sympathetic nervous system by mediating $50 \%$ of the Angll induced rise in blood pressure (10), and by facilitation of peripheral adrenergic neurotransmission, inhibition of norepinephrine uptake, and potentiation of postjunctional responses of SMC to $\alpha$, -adrenoreceptor stimulation (11-14). Both in vitro, and in vivo studies provide evidence that catecholamines can influence SMC DNA synthesis (15-18).

To test the hypothesis that SMC DNA synthesis induced by infusion of AngIl is mediated through stimulation of $\alpha_{1}$-adrenoreceptors, Angll was infused together with the specific $\alpha_{1}$-adrenoreceptor antagonist prazosin in normal adult rats. DNA synthesising vascular SMC were labeled by the concomitant infusion of 5 -bromo2'-deoxyuridine (19). The results indicate that the induction of vascular smooth muscle cell DNA synthesis by AngII is indeed dependent upon $\alpha_{4}$ adrenoreceptor stimulation and probably independent of the rise in blood pressure.

\section{MATERIALS AND METHODS}

Male adult Wistar Kyoto rats $(n=33, \mathrm{BW} 300-350 \mathrm{~g})$ were randomly assigned to one of five groups and received $0.9 \% \mathrm{NaCl}(\mathrm{n}=6)$, Angll $(\mathrm{n}=8)$, Angll and $50 \%$ DMSO $(n=4)$, Angll and prazosin in 50\% DMSO $(n=9)$, or $50 \%$ DMSO $(n=6)$.

\section{Experimental protocol}

The total duration of the experiment was three weeks. During these weeks systolic blood pressures (SBP) were measured (3 times/week). In the first week basal SBP was measured. At the beginning of the second week, infusions of Angll, prazosin, or its solvents, and BrdUrd were started and were continued for 14 days.

\section{Blood pressure measurement}

Systolic blood pressures were measured by the tail-cuff plethysmograph method as described in chapter 2.3 .

\section{Drug infusion protocol}

Infusions were given for 14 days by osmotic minipumps as described in chapter 2.2.2. Angll or $0.9 \% \mathrm{NaCl}$ were infused continuously (Alzet model 2001). Rat Angll was dissolved in $0.9 \% \mathrm{NaCl}$ and infused at a rate of $0.5 \mathrm{mg} / \mathrm{kg} / \mathrm{day}$. During the same surgical session a second osmotic minipump (Alzet model $2 \mathrm{mll}$ ) lilled 
with prazosin dissolved in 50\% DMSO (Angll+praz group) or filled with $50 \%$ DMSO (the AngJI+DMSO group and the DMSO group). Prazosin was dissolved in $50 \%$ DMSO and infused at a rate of $5 \mathrm{mg} / \mathrm{kg} / \mathrm{day}$.

At the same time as drug infusion Brdurd was given to all rats via a separate s.c implanted osmotic minipump and infused at a rate of $2.2 \mathrm{mg} / \mathrm{kg} / \mathrm{day}(30 \mathrm{mg} / \mathrm{mL}$ in $0.9 \% \mathrm{NaCl}$; Alzet model 2001).

All infusions were continued for two weeks. The minipumps were implanted at day 0 and replaced after one week.

\section{Assessment of $\alpha_{1}$-adrenoreceptor blockade by prazosin}

The degree of vascular $\alpha_{1}$-adrenoreceptor blockade was tested in a separate series of experiments by establishing the ED50 for phenylephrine in controll and prazosintreated Wistar Kyoto rats. Prazosin, dissolved in $50 \%$ DMSO, was given via a s.c. implanted osmotic minipump (Alzet model $2 \mathrm{ml} 1$ ) for one week at an infusion rate of $2.5 \mathrm{mg} / \mathrm{kg} /$ day. Control rats received an osmotic minipump (Alzet model $2 \mathrm{mll}$ ) filled with $50 \%$ DMSO. As described in chapter 2.2.3, a dose-response curve of phenylephrine was made after one week of prazosin infusion. The ED50 was calculated as the dose resulting in $50 \%$ of the maximal response.

\section{Tissue processing}

Two weeks after the start of the infusions, the animals were sacrificed in deep ether anesthesia and their arterial system perfusion fixed for 5 minutes with $10 \%$ phosphate buffered formalin as described in chapter 2.4 , after which the thoracic aorta was excised and further processed.

\section{Immunohistochemistry}

$4 \mu \mathrm{m}$ Cross sections of the thoracic aorta were stained immunohistochemically for BrdUrd. BrdUrd-labeled nuclei were visualized using an indirect enzyme labeled antibody technique as described in chapter 2.5.1. After immunostaining the cumulative labeling fraction (LF) for medial smooth muscle cells was determined (three cross sections/animal). Cross-sectional area was measured on Lawson stained cross-sections (chapter 2.5.2). 


\section{RESULTS}

\section{Assessment of $\alpha_{1}$-adrenoreceptor blockade by prazosin}

At the prazosin dose of $0.17 \mu \mathrm{g} / \mathrm{min} .100 \mathrm{~g}$, which is $50 \%$ of the dose used in the current study, the $\mathrm{ED}_{50}$ for phenylephrine was $0.10 \pm 0.02 \mu \mathrm{g} / \mathrm{kg} \cdot \mathrm{min}$ in control animals and $8.7 \pm 1.8 \mu \mathrm{g} / \mathrm{kg} \cdot \mathrm{min}$ in prazosin treated animals (mean $\pm \mathrm{SEM}, \mathrm{n}=5$ ), indicating that an approximate 160 fold-shift in the dose response of phenylephrine was obtained with the dose of prazosin used in the current study.

\section{Effects of AngII and prazosin on systolic blood pressure}

Systolic blood pressures increased more than $40 \mathrm{mmHg}$ within the first week of Angll infusion and remained at that level throughout the second week (figure 4.1). The increase in blood pressure in animals infused with Angll and DMSO was similar to the increase in blood pressure of animals infused with Angll alone (figure 4.1). Blood pressures were not increased by infusion of DMSO. Prazosin did not significantly affect the increase in systolic blood pressure induced by AngII (figure 4.1).

The bodyweight of animals treated with AngII (Angll, AngII + DMSO, AngIItprazosin) was significantly reduced, while the bodyweight of the animals in the other groups did not change (data not shown).

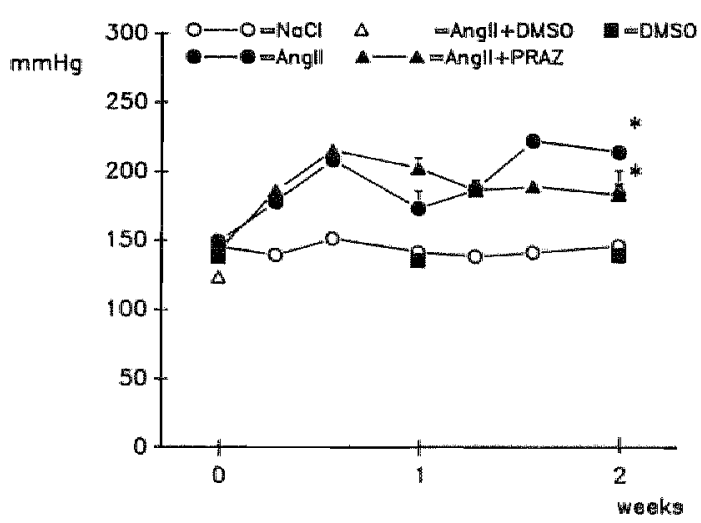

Figure 4.1 The development of the systolic blood pressure during continous Angll infusion and Angll-prazosin infusion. Rats received $0.9 \% \mathrm{NaCl}(\mathrm{NaCl})$, Angll (Angll), Angll and 50\% DMSO (Angll-DMSO), Angll and prazosin (Anglltprazosin), or 50\%DMSO (DMSO) *) Significantly different from group A. ') significantly different from the $\mathrm{NaCl}$ group, $\mathrm{p}<0.05$. 

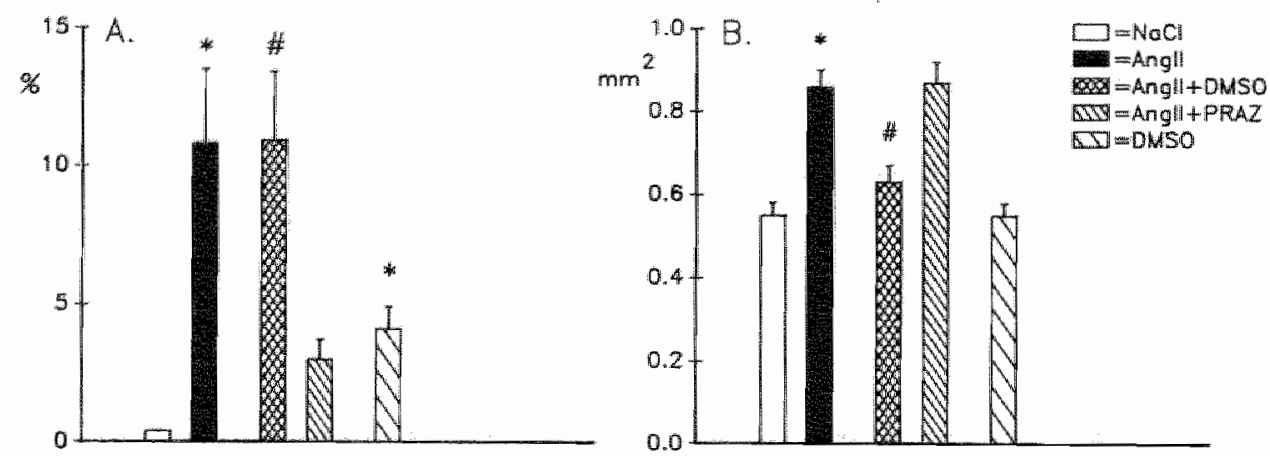

Figure 4.2 (A) Cumulative smooth muscle cell labeling fractions $(\%)$ in the media of the thoracic aorta; $(B)$ cross-sectional areas of the media of the thoracic aorta $\left(\mathrm{mm}^{2}\right)$. Group $\mathrm{NaCl}$ represent WKY rats receiving $0.9 \% \mathrm{NaCl}$, group Angll received Angll, group Angll+DMSO received AngII and 50\% DMSO. Group Anglltpraz received AngIl and prazosin in 50\% DMSO, and group DMSO received $50 \%$ DMSO and $0.9 \% \mathrm{NaCl}$. Data represent meantSEM, *) significantly different from the $\mathrm{NaCl}$ group,

\section{Effects of AngII and prazosin on medial smooth muscle cell DNA synthesis}

The cumulative labeling fraction of SMC in the media of the thoracic aorta increased during Angll infusion from $0.4 \pm 0.1 \%$ in the $\mathrm{NaCl}$ group to $10.8 \pm 2.7 \%$ (figure 4.2A). The infusion of Angll and DMSO increased SMC DNA synthesis to a similar extent as Angll alone (figure 4.2A). Prazosin significantly reduced the LF from $10.9 \pm 2.5 \%$ in the AngII+DMSO group to $3.0 \pm 0.7 \%$. in the AngII+prazosin group (figure $4.2 \mathrm{~A}$ ), but the LF in this group was still increased as compared to animals in the $\mathrm{NaCl}$ group. Two weeks of infusion with DMSO, the vehicle of prazosin, increased the medial SMC LF to $4.1 \pm 0.8 \%$, which is not different from the LF of animals in the Angll+prazosin group.

\section{Effects of Angll and prazosin on medial cross-sectional area}

Angll infusion increased the cross-sectional area of the media of the thoracic aorta from $0.55 \pm 0.03 \mathrm{~mm}^{2}$ in the $\mathrm{NaCl}$ group to $0.86 \pm 0.04 \mathrm{~mm}^{2}$ (figure $4.2 \mathrm{~B}$ ). Infusion of prazosin did not affect this parameter: the CSA of the thoracic aorta in the Angll-prazosin animals was similar to the CSA of the thoracic aorta in the Angll treated group. Infusion of DMSO did not affect medial cross-sectional area. 


\section{DISCUSSION}

The present study contains several distinct observations. First of all the data confirm our previous results that continuous infusion of Angll increases SMC DNA synthesis in the media of the thoracic aorta of the rat (6). The stimulatory effect of AngII on SMC DNA synthesis, however, was markedly decreased by co-treatment with the $\alpha_{1}$-adrenoreceptor antagonist prazosin. A third interesting observation was the dissociation between the effects of $\alpha_{1}$-adrenoreceptor blockade on the AngIIinduced increase in medial cross-sectional area and systolic blood pressure, and the induction of arterial smooth muscle cell DNA synthesis. While the AngII induced increase in DNA synthesis was almost completely prevented by prazosin, the drug was not effective in lowering the Angll induced increase in systolic blood pressure or medial cross-sectional area.

Labeling fractions in the media of the thoracic aorta of animals cotreated with prazosin were reduced by $50 \%$ as compared with levels in animals infused with AngII. The failure of the antagonist to lower replication rates to control levels could represent a dose-response problem, since only one dose of prazosin was used. This is unlikely however, since prazosin caused an approximate 160 foldshift in the dose response of phenylephrine, indicating effective blockade of the $\alpha_{1}$ adrenoreceptor. It is also possible that, although prazosin was completely effective, the inhibitory effects of prazosin were masked by the unexplained mitogenic effects of the vehicle DMSO, that was used for the continuous delivery of prazosin via osmotic minipumps. Another possibility is that prazosin blocked not only the $\alpha_{1}$-adrenoreceptor, but also the $\alpha_{2}$-adrenoreceptor. Prazosin has, like other $\alpha_{1}$-adrenoreceptor antagonists, the ability to block the $\alpha_{2}$-adrenoreceptor. It has been shown however, that prazosin is a highly selective $\alpha_{1}$-adrenoreceptor antagonist with a more than 250 times higher affinity for the $\alpha_{1}$-adrenoreceptor than for the $\alpha_{2}$-adrenoreceptor (20), which makes possible $\alpha_{2}$-adrenoreceptor blocking effects of prazosin in the current study very unlikely.

Thus the data suggest that the in vivo effects of AngIl infusion on SMC DNA synthesis are indirect, and mediated via stimulation of the $\alpha_{1}$-adrenoreceptor. The sympathetic nervous system and especially $\alpha_{1}$-adrenoreceptor mediated activity is known to play a role in vascular growth control, but the effects are complex and seem to be age-dependent. While sympathectomy greatly decreases DNA synthesis in the central ear artery of growing rabbits (15) and attenuates the hypertrophic response of cerebral arteries in young SHR (21) the opposite occurs in vessels of adult animals (22). Gene expression studies suggest a possible mechanism for growth stimulation by angiotensin II requiring $\alpha_{1}$-adrenoreceptor mediated activity. We have shown that the $\alpha_{1}$-adrenergic agonist phenylephrine can directly stimulate 
vascular smooth muscle to transcribe the mRNA of the platelet-derived growth factor A-chain gene, a possible endogenous growth factor (23). In vitro autocrine studies with anti-PDGF antibodies suggest that expression of PDGF may be necessary for growth stimulatory effects of $I L-1, T G F-B$ and AngII on SMC $(24,25)$.

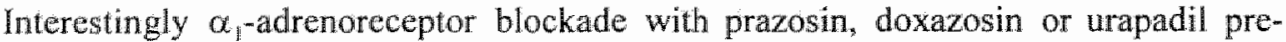
vents the development of a neointima after balloon injury (26-29).

While the data presented in this study show the involvement of the $\alpha_{1}$-adrenoreceptor in the induction of vascular SMC DNA synthesis by AngII in vivo, the exact mechanism of interaction remains unclear. AngIl enhances sympathetic activity both centrally and peripherally. Since the aorta of an adult rat has a very limited sympathetic innervation (30), interactions at the central level are unlikely to be important, although central stimulation of the adrenal medulla to release catecholamines in the plasma cannot be excluded. At the level of the peripheral sympathetic nervous system Angll stimulates release of norepinephrine from adrenergic varicosities at the nerve terminal via stimulation of presynaptic AT-receptors, inhibits the re-uptake of norepinephrine and increases post-junctional responses of SMC to norepinephrine-mediated $\alpha_{1}$-adrenergic stimulation $(12-14,31)$. Assuming that peripheral modulation of $\alpha_{1}$-adrenergic activity by AngII is important, this may occur via serial or parallel stimulation. Serial stimulation implies that stimulation of $\alpha_{1}$-adrenoreceptor mediated activity is a prerequisite for the stimulatory effects of AngII on vascular SMC DNA synthesis. This would indicate that the $\alpha_{1}$-adrenoreceptor and not AngIl is the control molecule. The parallel stimulation hypothesis implies that both systems are important in the control of SMC DNA synthesis and may act independently.

Our earlier observation that a single injection of the $\alpha_{1}$-adrenergic agonist phenylephrine did not increase vascular SMC DNA synthesis (22) does not help to discriminate between the two hypotheses, since it only indicates that a brief increase in plasma levels of phenylephrine is apparently not enough to stimulate SMC DNA synthesis. More experiments, like a continuous infusion of phenylephrine, are needed to elucidate the exact mechanism involved.

It was found that prazosin dissociated the response of AngII on SMC DNA synthesis from its hypertrophic response. While the drug significantly inhibited the increase in SMC DNA synthesis induced by AngIl it did not affect the AngIl induced increase in systolic blood pressure and medial cross-sectional area. Other authors have reported before that medial hypertrophy is controlled by increases in blood pressure, while other factors may be important in the control of vascular smooth muscle cell number. For instance Owens (32) found that antihypertensive treatment with a combination of reserpine, hydralazine and chlorothiazide prevented smooth muscle cell hypertrophy but not an increase in cell number in the thoracic aorta of adult SHR. The same author described that the effect of the angiotensin I conver- 
ting enzyme (ACE) inhibitor captopril on medial hypertrophy and the frequency of smooth muscle cell polyploidy was over and above that predicted by its blood pressure lowering effects and suggested a role of Angh in the control of vascular growth (33). In agreement with this is the increase in SMC DNA synthesis in vessel segments protected from the blood pressure rise during aortic coarctation, an Angll-dependent model of hypertension (34).

Recent in wivo experiments from Griffin et al. (35) extend the concept that Angll may have hypertrophic effects independent of mitosis. These authors showed that AngII infusion also stimulates hypertrophy of the rat mesenteric artery, but addition of hydralazine to Angll to prevent the blood pressure rise during Angll infusion had no effect on mesenteric arterial hypertrophy. An important difference between the study presented here and the Griffin study is the vessel examined. Heterogeneity along the vascular tree is very well possible and our clata are therefore extended to smaller vessels described in the next chapter. 


\section{REFERENCES}

1. Ross, R: The pathogenesis of atherosolerosis-an update. N Engl I Med 1986;314:488-500.

2. Sehwartz, SM; Campbell, GR; Campbell, JH: Replication of smooth muscle cells in vascular disease. Circ Res 1986;58:427-444.

3. Liu, MW: Roubin, GS; King, SB, 3d: Restenosis after coronary angioplasty. Potential biologic determinants and role of intimal hyperplasia. Circulation 1989,79:1374-1387.

4. Dzau, VJ: Multiple pathways of angiotensin production in the blood vessel wall: evidence, possibilities and hypotheses. IHypertens 1989;7:933-93.6.

5. Powell, JS; Clozel, JP; Muller, RK; Kuhn, H; Hefti, F; Hosang, M; Baumgartner, HR: Inhibitors of angiotensin-converting enzyme prevent myointimal proliferation after vascuUar injury. Science 1989;245:186-188.

6. Daemen, MJ; Lombardi, DM; Bosman. FT; Schwart, SM: Angiotensin II induces smooth muscle cell proliferation in the normall and injured rat arterial wall. Circ Res 1991;68:450456.

7. Owens, GK: Schwartz, SM: Vascular smooth muscle cell hypertrophy and hyperploidy in the Goldblatt hypertensive rat. Circ Res 1983;53:491-501.

8. Geisterfer, AA; Peach, MJ; Owens, GK: Angiotensin II induces hypertrophy, not hyperplasia, of cultured rat aortic smooth musclle cells. Circ Res $1988 ; 62: 749-756$.

9. Turla, MB; Thompson, MM; Corjay, MH; Owens, GK: Mechanisms of angiotensin II- and arginine vasopressin-induced increases in protein synthesis and content in cultured rat aortic smooth muscle cells. Evidence for selective increases in smooth muscle isoactin expression. Circ Res 1991;68:288-299.

10. Faber, JE; Brody, MJ: Central nervous system action of angiotensin during onset of renal hypertension in awake rats. Am J Physiol 1984;247/4349-1360.

11. Zimmerman, BG; Sybert, EJ; Wong, PC: Interaction between sympathetic and reninangiotensin system. J Hypertens 1984;2:581-587.

12. Luft, FC; Wilcox, CS; Unger, T; Kuhn, R; Demmert, G; Rohmeiss, P; Ganten, D, Sterzel, RB: Angiotensin-induced hypertension in the rat. Sympathetic nerve activity and prostaglandins. Hypertension 1989; 14:396-403

13. Leier, $\mathrm{CV}$; Binkley, PF; Cody, RJ; Alpha-adrenergic component of the sympathetic nervous system in congestive heart failure. Circulation 1990;82(Suppl.1):168-176.

14. Story, DF; Ziogas, I: Interaction of angiotensin with noradrenergic neuroeffector transmission. Trends Phamcological Science 1987;8:269-271. 
15. Bevan, RD: Effect of sympathetic denervation on smooth muscle cell proliferation in the. growing rabbit ear artery. Circ Res 1975;37:14-19.

16. Blaes, N; Boissel, IP: Growth-stimulating effect of catecholamines on rat artic smooth muscle cells in culture. J Cell Physiol 1983;116:167-172.

17. Yamon, $Y$; Mano, M; Nara, $Y$; Horie, R: Catecholanine-induced polyploidization in vascular smooth muscle cells. Circulation 1987;75(Suppl.1):192-195.

18. Nakaki, T; Nakayama, M; Yamamoto, S; Kato, R: Alpha 1-adrenergic stimulation and beta 2-adrenergic inhibition of DNA synthesis in wascular smooth muscle cells. Mol Pharmacol 1990;37:30-36.

19. Gratzner, HG: Monoclonal antibody to 5-bromo- and 5-iododeoxyuridine: a new reagent for detection of DNA replication. Science $1982 ; 218: 474-475$.

20. Timmermans, PBMWM; Van Meel, JCA; Van Zwieten, PA: Evaluation of the selectivity of $\alpha$-adrenoreceptor blocking durgs for post-synaptic $\alpha 1$ and $\alpha 2$-adrenoceptors in a simple animal model. J Auton Pharmacol 1980;3:53-60.

21. Sadoshima, S; Fujii, K; Yao, H; Ibayashi, S; Fujishima, M: Effect of chronic sympathetic denervation on cerebrovascular hypertrophy during the development of hypertension in rats. Brain Res 1986;379:205-209.

22. Todd, ME; Gowen, B: Arterial wall and smooth muscle cell development in young Wistar rats and the effects of surgical denervation. Circ Res 1991;69:438-446.

23. Majesky, MW; Daemen, MJ; Schwartz, SM: Alpha 1-adrenergic stimulation of piateletderived growth factor A-chain gene expression in rat aorta. J Biol Chem 1990;265:10821088 .

24. Naftilan, AJ; Pratt, RE; Dzau, VJ: Induction of platelet-derived growth factor A-chain and c-myc gene expressions by angiotensin $\| 1$ in cultured rat vascular smooth muscle cells. I Clin Invest 1989:83:1419-1424.

25. Raines, EW; Dower, SK; Ross, R: Interleukin-I mitogenic activity for fibroblasts and smooth muscle cells is due to PDGF-AA. Science 1989;243:393-396.

26. Jackson, CL; Bush, RC; Bowyer, DE: Inhibitory effecil of calcium antagonists on balloon catheter-induced arterial smooth muscle cell proliferation and lesion size. Atlerosel 1988;$69: 115-122$

27. OMalley, MK; MoDermott, EW; Mehigan, D; O’Higgins, NI: Role for prazosin in reducing the development of rabbit intimal hyperplasia after endothelial denudation. Br $J$ Surg $1989: 76: 936-938$.

28. Fingerle, J; Sanders, KH; Fotew, Z: Alpham receptor antagonists urapidil and prazosin inhibit neointima formation in rat carotid artery induced by balloon catheter injury. Basic 
Res Cardiol 1991;86 (Suppl.1):75-81.

29. Vashisht, $R$; Sian, M; Franks, PJ; O'Malley, MK: Long-term reduction of intimal hyperplasia by the selective alpha-I adrenergic antagonist doxazosin. $\mathrm{Br}$ \& Surg 1992;79:12851288 .

30. Bevan, JA; Bevan, RD; Duckles, SP: Adrenergic regulation of vascular smooth muscle, in Bohr DF; Sombyo, AP; Sparks, HV (eds.): Handbook of Physialogy. Bethesda, Md, American Physiological Society, $1980: 515-566$.

31. Zimmerman, BG: Adrenergic facilitation by angiotensin: does it serve a physiological function. Clin Sci 1981;60:343-348.

32. Owens, GK; Reidy, MA: Hyperplastic growth response of vascular smooth muscle cells following induction of acute hypertension in rats by aortic coarctation. Circ Res 1985;57:$695-705$.

33. Owens, GK: Influence of blood pressure on development of aortic medial smooth muscle hypertrophy in spontaneously hypertensive rats. Hypertension 1987;9:178-187.

34. Plunkett, WC; Overbeck, HW: Increased arteriolar wall to lumen ratio in a normotensive vascular bed in coarctation hypertension. Am J Physiol 1985;249:H849-H866.

35. Gniffin, SA; Brown, WC; MacPherson, F; McGrath, JC; Wilson, VG; Korsgaard, N;

Mulvany, MJ; Lever, AF: Angiotensin II causes vascular hypertrophy in part by a nonpressor mechanism. Hypertension 1991;17:626-635. 
HETEROGENEITY OF THE ANGIOTENSIN II INDUCED RAT VASCUL AR SMOOTH MUSCLE CELL DNA SYNTHESIS: EFFECTS OF ALPHA ONE ADRENORECEPTOR BLOCKADE 


\section{SUMMARY}

The effects of Angll infusion ard the effects of $\alpha_{i}$-adrenoceptor blockade were studied in 4 different rat elastic arteries: the left caratid, the superior mesenteric, the laft renal, the lefi femorat artery. The experimental protocal was similar to the one described in chapter 4. Angll caused a significant increase in the fraction of DNA synhesizing SMC in the media of all arteries, but the extent of DNA synthesis differed between the arteries: the greatest increase in labeling fraction was found in the renal artery, from $3.0 \pm 1.3 \%(n=6)$ in the $\mathrm{NaCl}$ group to $32.4 \pm 4.0 \%(n=5)$ in the Angll infused rats. The labeling fractions during Angll infusion of the other arteries were $19.2 \pm 31 \%(n=7)$ in the femoral artery, $14.7 \pm 4.7 \%(n=7)$ in the superior mesenteric artery, and $8.3 \pm 1.9 \%(n=7)$ in the carotid artery. Addition of prazosin reduced the labeling fraction of vascular SMC in all arteries but one, the superior mesenteric artery. Both systolic bload pressure and medial cross-sectional areas of these arteries increased during Angll infusion, but these parameters were not altered by prazosin. We conclude that the growth response to Angll and the

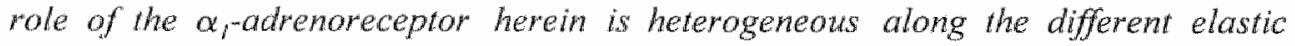
arleries lested.

\section{INTRODUCTION}

Different arteries have been shown to respond differently in their extent of medial SMC DNA synthesis to similar growth stimuli in arterial organoid culture (1). Also in the young, 6-week old spontaneously hypertensive rat (SHR) in vivo there is a heterogeneous distibution of SMC DNA synthesis along the vascular tree (2). Heterogeneity in growth response thas also been demonstrated in the adult SHR: large arteries show a hypertrophic response in conduit arteries, whereas small resistance arteries respond with hyperplasia $(3,4)$.

Angll has been shown to stimulate SMC DNA synthesis in vivo in a variety of rat arteries, including the thoracic aorta, the carotid artery (5), and the renal artery (6). In the previous chapter we showed that the $\alpha_{1}$-adrenoreceptor is involved in the regulation of SMC DNA synthesis in the thoracic aorta by Angll. To further explore the effects of Angl infusion and the effects of $\alpha_{1}$-adrenoreceptor blockade with prazosin on SMC DNA synthesis in other arteries, we extended our study to four different, elastic arteries with an almost equal internal diameter and medial crosssectional area: the carotid, superior mesenteric, renal and femoral artery. 


\section{MATERIALS AND METHODS}

\section{Experimental protocol}

The experimental protocol is similar to the protocol described in chapter 4 . The experiment lasted 3 weeks, during which blood pressure measurements were taken ( 3 times/week). At the start of the second week all animals were infused by s.c. implanted osmotic minipumps (2.2.2) and receiwed: $0.9 \% \mathrm{NaCl}(n=8)$, Angll $(n=8)$, Angll and 50\% DMSO ( $\mathrm{n}=4$ ), which is the solvent of prazosin, AngII and prazosin $(n=9)$, or $50 \%$ DMSO $(n=6)$. The infusions were continued for 14 days, subsequently the animals were sacrificed and the left carotid, left renal, left femoral and the superior mesenteric artery were excised and further processed (chapter 2.4). 4 $\mu \mathrm{m}$ Cross-sections were stained immunohistochemically for BrdUrd as described in 2.5.1. The cumulative labeling fraction in the media was determined (three crosssections/animal) as an indicator of SMC DNA synthesis. Medial cross-sectional area was measured using a computerized morphometry system (2.5.2).

\section{RESULTS}

The effects of Angll and prazosin on systolic blood pressure have been described in the previous chapter, and are depicted in figure 4.1. Briefly, Angll infusion (in the AngIl group and AngII+DMSO group) increased systolic blood pressure; concomitant infusion of prazosin did not affect the AngII induced increase in systolic blood pressure.

\section{Effects of AngII and prazosin on medial smooth muscle cell DNA synthesis}

\section{Heterogeneity of the effects of Ang II}

The DNA labeling fractions in the media of the four rat elastic arteries are summarized in figure 5.1A. In the renal artery Angll infusion caused an increase in SMC labeling fraction in the media from $3.0 \pm 1.3 \% \quad(n=6)$ in the $\mathrm{NaCl}$ group to $32.4 \pm 4.0 \%(\mathrm{n}=5)$. Angll and DMSO $(\mathrm{n}=4)$ caused a similar increase in labeling fraction, $31.8 \pm 7.5 \%$, as AngII alone. Infusion of DMSO alone increased SMC DNA synthesis to $6.4 \pm 2.6 \%(\mathrm{n}=4)$.

Also in the other arteries AngII infusion stimulated SMC DNA synthesis (figure 5.2). However, the increase in DNA synthesis differed between the arteries investigated. The AngII induced SMC DNA synthesis was greatest in the renal artery, followed by the femoral arterty $(19.2 \pm 3.1 \%)$, the superior mesenteric artery $(14.7 \pm 4.7 \%)$ and the carotid artery $(8.3 \pm 1.9 \%)$. 

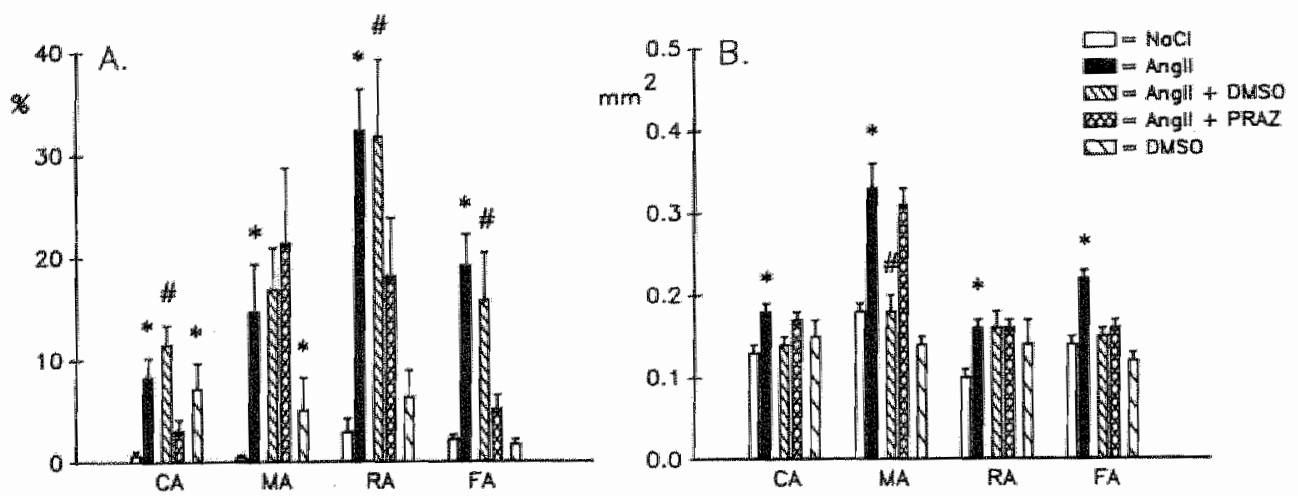

Figure 5.1 (A) Cumulative smooth muscle cell labeling fractions $(\%)$ in the media and (B) crosssectional areas $\left(\mathrm{mm}^{2}\right)$ of the mediat of the left carotid artery (CA), the superior mesenteric artery (MA), the left renal artery (RA) and the left femoral artery (FA). Group NaCl represent WKY rats receiving $0.9 \% \mathrm{NaCl}$, group Angll received Angll, group Angll $+\mathrm{DMSO}$ received Angll and $50 \%$ DMSO. Group Anglltpraz received AngIl and prazosin in 50\% DMSO, and group DMSO received $50 \%$ DMSO and $0.9 \% \mathrm{NaCl}$. Data represent mean $\pm \mathrm{SEM},{ }^{*}$ ) significantly different firom the $\mathrm{NaCl}$ group, Hignificantly different from the Anglltpraz group, $\mathrm{p}<0.05$.

Heterogeneity of the effects of prazosin

Addition of prazosin to Angll reduced the labeling fraction in the renal artery from $31.8 \pm 15.1 \%$ in the AngIJ+DMSO group to $18.2 \pm 5.7 \%$ in the AngII+prazosin group. In the carotid and femoral artery, addition of prazosin also resulted in a significant reduction in SMC DNA synthesis (figure 5.1A). In the superior mesenteric artery prazosin did not reduce SMC DNA synthesis: the labeling fraction in the media remained at a high level of $21.4 \pm 7.2 \%$ versus $16.9 \pm 4.1 \%$ in the AngII+DMSO treated animals. In all arteries, infusion of DMSO did not affect Angll induced SMC DNA synthesis.

\section{Effects of Angll and prazosin on medial cross-sectional area}

The effects of Angll and prazosin on medial cross-sectional area of the four elastic arteries are summarized in figure $5.1 \mathrm{~B}$. AngIl infusion increased the cross-sectional area of the media of all arteries. In the renal artery an increase in cross-sectional area was found from $0.10 \pm 0.01 \mathrm{~mm}^{2}$ to $0.16 \pm 0.01 \mathrm{~mm}^{2}$. Addition of prazosin did not change the Angll induced increase in cross-sectional area, $0.16 \pm 0.01 \mathrm{~mm}^{2}$. Comparable effects were found in the three other arteries (figure 5.1B). Infusion of DMSO did not affect medial cross-sectional area. 


\section{DISCUSSION}

This study draws attention to the effects of angiotensin 11 along different elastic arteries of the rat, and has two distinct points of interest: firstly, AngII infusion causes a heterogeneous increase in SMC DNA synthesis in the arteries investigated. Secondly, it shows that the effects of $\alpha_{1}$-adrenoreceptor blockade also are heterogeneous: the $\alpha_{1}$-adrenoreceptor mediates the Angll induced DNA synthesis in the carotid, renal and femoral artery, but not in the superior mesenteric artery. Heterogeneity in SMC DNA synthesis has been described before (2). When the distribution of SMC DNA synthesis over the vascular tree was compared between 6 weeks old WKY rats and 6 weeks old SHR with marginally elevated blood pressure, a significantly higher SMC DNA synthesis was found in the aorta, superior mesenteric, renal and femoral arteries of the SHR as compared to the WKY. Comparison of the SMC DNA synthesis between the arteries of the SHR showed a higher SMC DNA synthesis in the large arteries than in the resistance arteries, but no differences in DNA synthesis within the elastic arteries. In another study, BrdUrd incorporation was measured in organoid cultures of carotid, renal, femoral and superior mesenteric artery segments of adult normotensive rats (1). 20\% Fetal calf serum stimulated medial SMC DNA synthesis most markedly in renal arteries, followed by the carotid artery and thoracic aorta. The effect was least pronounced in the superior mesenteric artery and femoral artery. In the current study the renal artery was also found to have the highest medial DNA synthesis, which could imply that the renal artery is more sensitive to growth induction.

The prazosin effects on AngII induced SMC DNA synthesis also showed a certain degree of heterogeneity. While the drug reduced the AngII induced SMC DNA synthesis in the carotid, renal and femoral artery with more than $50 \%$, a similar effect as we described in the previous chapter for the thoracic aorta, it had no effect on the Angll induced SMC DNA synthesis in the superior mesenteric artery. Although we have no real clue on the cause of this "heterogeneity" several possible explanations have to be considered. First, heterogeneity in $\alpha_{1}$-adrenoreceptor density and/or subtype has to be considered. This is however unlikely since the superior mesenteric artery of an adult rat is densily innervated and contains $\alpha_{1}$-adrenoreceptors (7). Second, prazosin might have a low affinity for one of the $\alpha_{1}$-adrenoreceptor subtypes in the rat superior mesenteric artery. Two different $a_{1}$-adrenoreceptor subtypes have been distinguished by both competitive antagonists studies and molecular cloning (8-11). The mesenteric artery of the rat contains a mixture of both $\alpha_{1 \mathrm{~A}}$ and $\alpha_{1 \mathrm{~B}}$-adrenoreceptor subtypes (8). Affinity studies with prazosin showed that it has differential affinities for the $\alpha_{1}$-adrenoreceptor in different vessels and different species, but prazosin is shown to have a similar affinity in the rat aorta and rat mesenteric artery (12). These findings are confirmed by a recent study 
in which prazosin does not distinguish between the cloned rat $\alpha_{1 \mathrm{~A}}$ and rat $\alpha_{1 \mathrm{~B}}$ receptor (affinities expressed as $K_{i}$ values are respectively, 0.33 and $\left.0.56 \mathrm{nM}\right)(13)$. Thus, prazosin blocks both the $\alpha_{1 \mathrm{~A}}$ and $\alpha_{1 \mathrm{~B}}$-adrenoreceptors in the superior mesenteric antery.

Molecular cloning has also revealed a third $\alpha_{1}$-adrenoreceptor subtype, the $\alpha_{1 c^{-}}$ adrenoreceptor $(14,15)$, but its presence has not been described in rat tissues $(10$, $14,15)$.

Angll induced a significant increase in medial cross-sectional area of all arteries. The increase in medial area was most marked in the superior mesenteric artery. Again, this suggests that the growth effects of Angll are regionally heterogeneous. Infusion of Angll and DMSO did not increase medial cross-sectional area in any of the arteries as compared to the control group, receiving DMSO. Thus, it seems that DMSO prevents the AnglI induced increase in cross-sectional area. However, infusion of Angll together with prazosin and DMSO increased medial cross-sectionat areas of the carotid and superior mesenteric artery. Such an increase was also shown for the thoracic aorta (chapter 4), suggesting that prazosin neutralizes the reduction in cross-sectional area by DMSO.

In conclusion, the data presented in this study show that AngII induces SMC DNA synthesis in four different elastic arteries. The AngII induced SMC DNA synthesis was found to be heterogeneous along these arteries. The heterogeneous SMC DNA synthesis induced by AngII seems to be mediated via the $\alpha_{1}$-adrenoreceptor in the carotid, renal and femoral artery, but this effect of the $\alpha_{1}$-adrenoreceptor was not demonstrated for the rat superior mesenteric artery. 


\section{REFERENCES}

1. De-Mey, JGR; Uitendaal, MP; Boonen, HCM; Schiffers, PMH; Fazzi, GE: Growth responses in isolated elastic, muscular and resistance-sized arterial segments of the rat. Blood Vessels $1991,28: 372-385$.

2. De-Mey, JG; Daemen, MJ; Boonen, HC; Bosman, FT; Dijkstra, EH; Fazzi, GE; Janssen; GM; Schiffers, PM; Struyker-Boudier, HA; Vrijdag, MV: In vivo DNA synthesis is not uniformly increased in arterial smooth muscle of young spontaneously hypertensive rats. $J$ Hypertens 1991;9:695-701.

3. Owens, GK: Control of hypertrophic verstis lyyperplastic growth of wascullar smooth musscle cells. Am J Physiol 1989;257:H1755-H1765.

4. Mulvany, MJ; Aalkjaer, C: Structure and function of small arteries. Physiol Rev $1990 ; 70: 921-961$

5. van-Kleef, EM; Smits, JF; De-Mey, JG, Cleutjens, JP; Lombardi, DM; Schwartz, SM; Daemen, MJ: Alpha 1-adrenoreceptor blockade reduces the angiotensin II-induced vascular smooth muscle cell DNA synthesis in the rat thoracic aorta and carotid artery. Circ Res $1992 ; 70: 1122-1127$.

6. Johnson, RJ; Alpers, CE; Yoshimura, A; Lombardi, D; Pritzl, P; Floege, J; Schwartz, SM: Renal injury from angiotensin ll-mediated hypertension. Hypertension 1992;19:464-474.

7. Nilsson, $\mathrm{H}$; Goldstein, $\mathrm{M}$; Nilsson, $\mathrm{O}$ : Adrenergic innervation and neurogenic response in large and small arteries and veins from the rat. Acta Physiol Scand 1986;126:121-133.

8. Han, C; Li, J; Mimeman, KP: Subtypes of alpha 1-adrenoceptors in rat blood vessels. Eur J Pharmacol 1990,190:97-104.

9. Cotechia, S; Schwinn; DA; Randall, $\mathbb{R} \mathbb{R} ;$ Lefkowitz, RJ; Caron, MG; Kobilka, BK: Molecular cloning and expression of the CDNA for the hamster alpha l-adrenergic receptor. Proc Natl Acad Sci USA 1988;85:7159-7163.

10. Lomasney, JW; Cotechia, S; Lorenz, W; Leung, WY; Schwinn, DA; Yang-Feng, TL; Brownstein, M; Lefkowitz, RJ; Caron, MG: Molecular cloning and expression of the CDNA for the alpha 1 A-adrenergic receptor. The gene for which is located on humarl chromosome 5. J Biol Chem 1991;266:6365-6369.

11. Bruno, JF; Whittaker, J; Song, JF; Berelowitz, M: Molecular cloning and sequencing of at cDNA encoding a human alpha 1 A adrenergic receptor. Biochem Biophys Res Commun $1991 ; 179: 1485-1490$.

12. Flawahan. NA; Vanhoute, PM: al-Adrenoceptor subclassification in vascular smooth muscle. TIPS $1986 ; 7: 347-349$. 
13. Lomasney, JW; Cotechia, $\mathrm{S}$; Lefkowitz, R; Caron, MG: Molecular biology of alphaadrenergic receptors: implications for receptor classification and for structure-function relationships. Biochim Biophys Acta 1991;1095:127-139.

14. Schwinn, DA; Lomasney, JW; Lorenz, W; Szklut, PJ; Fremeau, RT, Ir; Yang-Feng, TL; Caron, MG; Lefkowitz, RJ; Cotecchia, S: Molecular cloning and expression of the cDNA for a novel alpha 1-adrenergic receptor subtype. J Biol Chem 1990;265:8183-8189.

15. Schwinn, DA; Page, SO; Middleton, JP; Lorenz, W; Liggett, SB; Yamamoto, K; Lapetina, $\mathrm{EG}$; Caron, MG; Lefkowitz, RJ; Cotecchia, S: The $\alpha$ lc-adrenergic receptor: characterization of signal transduction pathways and mammalian tissue heterogeneity. Mol Pharmacol $1991 ; 40: 619-626$. 
HETEROGENEOUS EFFECTS OF $\alpha_{1}$-ADRENORECEPTOR BLOCKADE WITH DOXAZOSIN ON THE ANGIOTENSIN II INDUCED SMOOTH MUSCLE CELL DNA SYNTHESIS IN THE BALLOON INIURED RAT CAROTID ARTERY 


\section{SUMMARY}

To investigate the role of the $\alpha_{1}$-adrenoreceptor in the AngII induced SMC DNA synthesis in the neointima, adult male Wistar Kyoto rats were subcutaneously infused for two weeks with Angll and the $\alpha$-adrenoreceptor antagonist doxazosin, during the $3^{\text {rd }}$ and $4^{\text {th }}$ week after balloon injury of the left conmon carotid artery. Control groups received AngII, $0.9 \% \mathrm{NaCl}$ (the solvent of AngII), AngII+50\% dimethylsulfoxide (DMSO, the solvent of doxazosin), or 50\% DMSO alone. Each rat received 5-bromo-2'-deoxyuridine (BrdUrd) in a separate asmotic minipump to label DNA synthesizing SMC. Angll infusion significantly increased the systolic blood pressure by approximately $60 \mathrm{mmHg}$. Addition of doxazosin did not affect the Angll induced increase in systolic blood pressure.

The BrdUrd labeling fraction (LF) in the media of the non-injured right carotid artery significantly increased from $0.3 \pm 0.1 \%$ in the $\mathrm{NaCl}$ group $103.1 \pm 0.8 \%$ in the Angll group. Addition of DMSO did not affect the increase in DNA synthesis. The $\alpha_{i}$-adrenoreceptor antagonist doxazosin significantly reduced the Angll induced SMC DNA synthesis. DMSO infusion alone did not affect the $L F$.

The $L F$ in the media of the injured left carotid artery was also increased by AngII: $1.8 \pm 0.7 \%$ in the Angll treated animals vs. $0.3 \pm 0.1 \%$ in the NaCl group. However, doxazosin did not reduce the Angll induced increase in LF. The LF in the DMSO group was comparable to the LF in the NaCl group.

In the neointima of the injured left carotid artery AngII also stimulated SMC DNA synthesis, restiting in a labeling fraction of $32.5 \pm 2.6 \% \mathrm{vs} .15 .8 \pm 3.3 \%$ in the $\mathrm{NaCl}$ group. Doxazosin or DMSO did not reduce this Angll increased SMC DNA synthesis. These data suggest that $\alpha_{5}$-adrenoreceptors are involved in Angll induced medial SMC DNA synthesis of the non-injured rat carotid artery, but not in SMC DNA synthesis in the injured left carotid artery.

\section{INTRODUCTION}

Several observations indicate that the sympathetic nervous system and especially $\alpha_{1}$-adrenoreceptors are involved in the regulation of vascular growth and in the response of the vessel wall to injury. In vitro, catecholamines induce SMC. DNA synthesis $(1,2)$, and this effect is mediated through $\alpha_{\mathbb{1}}$-adrenoreceptors (3). In the growing rabbit, sympathetic denervation of the ear artery reduces SMC DNA synthesis (4), and chemical sympathectomy with 6-hydroxydopamine reduces the number of SMC in the aortic media (5). In the rat, neonatal sympathectomy reduces the number of medial SMC layers in the large and small mesenteric arteries, but not in the superior mesenteric artery of spontaneously hypertensive rats (6). The $\alpha_{1}$-adrenoreceptor antagonists urapidil, prazosin and doxazosin reduce 
neointimal thickening in the balloon injured rat carotid artery and rabbit abdominal aorta (7-9). In addition, stimulation of $\alpha_{1}$-adrenoreceptors by the $\alpha_{1}$-agonist phenylephrine increases the expression of growth related genes, such as PDGF-A (10) in the rat thoracic aorta, suggesting a role for the $\alpha_{1}$-adrenoreceptor in the regulation of SMC growth. In chapters 4 and 5 of this thesis we showed that $\alpha_{1}$ adrenoreceptors are also involved in the AngII induced stimulation of SMC DNA synthesis in the media of elastic arteries, including the carotid artery. Since Angll not only stimulates SMC DNA synthesis in the media, but even more in the neointima (11), we tested the hypothesis that $\alpha_{1}$-adrenoreceptors are also involved in the AngII induced SMC DNA synthesis in the neointima.

Therefore we infused the specilic $\alpha_{1}$-adrenoreceptor antagonist doxazosin together with AngII in the $3^{\text {rd }}$ and $4^{\text {th }}$ week after balloon injury of the left common carotid artery. At the same time BrdUrd was infused. The results indicate that $\alpha_{1}$ adrenoreceptors are involved in the AngIl induced SMC DNA synthesis in the media of the non-injured rat carotid artery, but not in the neointima, nor in the media of the injured carotid artery.

\section{MATERIALS AND METHODS}

Male Wistar Kyoto rats (body weight $280-300 \mathrm{~g}$ ) were randomly divided into 5 groups. The experiment lasted fived weeks. Systolic blood pressures (SBP) were measured by tailcuff plethysmography (chapter 2.3). In the first week only blood pressure measurements were taken. At the start of the second week the left. common carotid artery was injured by a balloon catheter (chapter 2.2.1). Two weeks after balloon injury, continuous infusions by s.c. implanted minipumps were started with either AngII $(n=6), 0.9 \% \mathrm{NaCl}(n=6)$, AngII and 50\% DMSO ( $n=6)$, AngII and doxazosin ( $n=6)$, or $50 \%$ DMSO $(n=4)$. Concomitantly, each rat received BrdUrd, which was infused through a separate osmotic minipump. All infusions lasted for 2 weeks.

\section{Drug infusion protocol}

AngII was dissolved in $0.9 \% \mathrm{NaCl}$ and infused at a rate of $0.5 \mathrm{mg} / \mathrm{kg} /$ day (Alzet model 2002). Doxazosin was dissolved in 50\% DMSO, and infused at a rate of 48 $\mathrm{mg} / \mathrm{kg} /$ day (Alzet model $2 \mathrm{mll}$ ). At the same time, all rats received BrdUrd, that was infused at a rate of $0.8 \mathrm{mg} / \mathrm{kg} /$ day $(20 \mathrm{mg} / \mathrm{ml}$ in $0.9 \% \mathrm{NaCl})$ by a separate osmotic minipump (Alzet model 2002). 


\section{Tissue processing}

At the end of week 5, the rats were killed in deep ether anesthesia. The heart was excised and weighed. Both the left and right carotid arteries were directly isolated, fixed in 10\% phosphate buffered formalin overnight, routinely processed and embedded in paraffin. Cross-sections were cut $(4 \mu \mathrm{m})$ and stained immunohistochemically with an anti-BrdUrd antibody to measure SMC DNA synthesis (chapter 2.5.1). In addition, cross-sections were stained with Lawson solution to measure medial and intimal cross-sectional areas (chapter 2.5.2).

\section{Plasma catecholamine levels}

In a separate experiment arterial blood samples were collected to measure circulating catecholamine levels (chapter 2.6.1). Animals were continuously infused by s.c. implanted minipumps with AngII ( $\mathrm{n}=8,0.5 \mathrm{mg} / \mathrm{kg} / \mathrm{day})$, AngII and doxazosin $(\mathrm{n}=5,48 \mathrm{mg} / \mathrm{kg} /$ day $)$, or $0.9 \% \mathrm{NaCl}(\mathrm{n}=7)$ by s.c. implanted osmotic minipumps. Infusions were continued for two weeks. 5 Days before the end of infusion, animals were anesthetized and a polyethylene catheter was inserted into the lower abdominal aorta via the left femoral artery and guided s.c. to the neck were it was exteriorized and plugged. After $24 \mathrm{hr}$ recovery, $2 \mathrm{ml}$ blood was collected via the catheter.

\section{Assessment of $\alpha_{11}$-adrenoreceptor blockade with doxazosin}

The dose of doxazosin was determined in a separate experiment. Wistar Kyoto rats $(n=10)$ were infused with either doxazosin $(24 \mathrm{mg} / \mathrm{kg} / \mathrm{day})$ or $50 \%$ DMSO for one week. After one week dose-response curves were obtained by relating pressorresponses to the logarithm of the infusion-rate of phenylephrine $(0.01$ to $100 \mu \mathrm{g} / \mathrm{kg}$ per minute) (chapter 2.3). The $\mathrm{ED}_{50}$ was determined as the dose resulting in the half-maximal response.

\section{RESULTS}

\section{Assessment of $\alpha_{1}$-adrenoreceptor blockade with doxazosin}

In the present study doxazosin was used in a dose of $48 \mathrm{mg} / \mathrm{kg} / \mathrm{day}$. At a doxazosin dose of $24 \mathrm{mg} / \mathrm{kg} / \mathrm{day}$, the $E D_{50}$ for phenylephrine was $0.10 \pm 0.02 \mu \mathrm{g} / \mathrm{kg} / \mathrm{min}$ in control (50\% DMSO) rats $(\mathrm{n}=5)$ and $5.5 \pm 1.3 \mu \mathrm{g} / \mathrm{kg} / \mathrm{min}$ in doxazosin treated rats $(n=5)$, suggesting an approximate 100-fold shift in the dose response curve of phenylephrine with the $48 \mathrm{mg} / \mathrm{kg} /$ day dose of doxazosin used in the present study. 


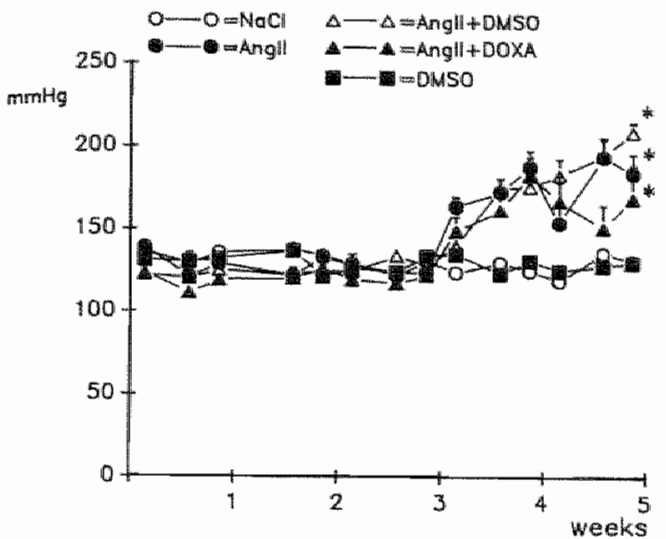

Figure 6.1 The development of the systolic blood pressure during infusion of Angll and Angll-doxazosin. Group $\mathrm{NaCl}(\mathrm{n}=6)$ received $0.9 \%$ NaCl, group Angll $(n=6)$ received Angll, group Angll+DMSO (n=6) received Angll and 50\% DMSO, group Anglltdoxa $(n=6)$ received AngII and doxazosin, and group DMSO $(n=4)$ received $50 \%$ DMSO. Data represent mean 1 SEM *) significantly different from the $\mathrm{NaCl}$ group, $\mathrm{p}<0.05$.

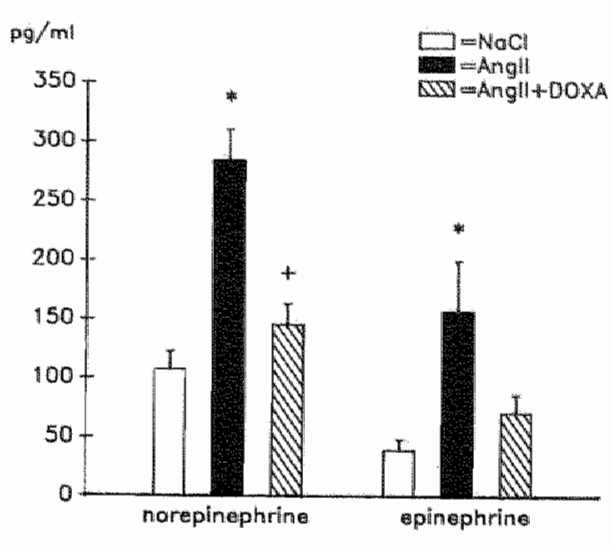

Figure 6.2 Plasma catecholamine levels (pg/mol) in non-balloonminjured WKY rats, infused with either $0.9 \% \mathrm{NaCl}(\mathrm{n}=7)$, Angll $(n=8)$, or Angll and doxazosin $(n=5)$. Data represent meantSEM. *) Significantly different from the $\mathrm{NaCl}$ group,+ ) significanily different from the Angll group, $p<0.05$.

\section{Effects of Angll and doxazosin on systolic blood pressure, body and heart weight}

At the start of the experiment systolic blood pressures (SBP) were approximately $130 \mathrm{mmHg}$ and there was no difference in SBP between the groups. Balloon injury did not affect blood pressure (figure 6.1), but subsequent infusion of the different agents caused blood pressure changes that were significantlly different in the treatment groups (figure 6.1). Infusion of Angll caused an increase in SBP by approximately $60 \mathrm{mmHg}$ within the first week of infusion, and the SBP remained increased during the second week of infusion. Addition of doxazosin did not affect the increase in SBP caused by Angll. Infusion of AngII and 50\% DMSO also increased SBP to levels comparable to those in the Angll and Angll doxa group. The SBP in all the AngIl treated groups (AngII, Angll+doxa, and AngII+DMSO) differed significantly from the SBP in the $0.9 \% \mathrm{NaCl}$ and $50 \%$ DMSO treated groups, in which SBP remained unchanged during the course of the experiment.

Rats treated with AngII or AngII+DMSO lost weight, respectively $27 \pm 1.7$ and $29 \pm 1.7 \mathrm{~g}$ over the time of infusion (table 6.1). The Anglltdoxa, the $\mathrm{NaCl}$ and the 
DMSO groups gained weight, respectively $+15 \pm 1.6 \mathrm{~g},+24 \pm 0.8 \mathrm{~g}$ and $+35 \pm 1.2 \mathrm{~g}$. The heart weight to body weight ratio in the groups receiving AngII was increased, which was mainly due to the differences in body weight at the end of the experiment, since neither the wet heart weight, nor the dry heart weight were significantly affected by Angll treatment (table 6.1).

Table 6.1 Body and heart weight parameters

\begin{tabular}{|c|c|c|c|c|c|}
\hline Groups & $\begin{array}{l}\mathrm{NaCl} \\
(n=6)\end{array}$ & $\begin{array}{l}\text { Angll } \\
(n=6)\end{array}$ & $\begin{array}{c}\text { Angll } \\
\text { DMSO } \\
(n=6)\end{array}$ & $\begin{array}{c}\text { Anglt } \\
\text { doxa } \\
(n=6)\end{array}$ & $\begin{array}{r}\text { DMSO } \\
(n=4)\end{array}$ \\
\hline $\begin{array}{l}\text { Body weight } \\
\text { (g) }\end{array}$ & $354 \pm 9$ & $282 \pm 13^{\circ}$ & $284 \pm 7^{*}$ & $307 \pm 12^{\circ}$ & $386 \pm 10$ \\
\hline $\begin{array}{l}\text { Change in body } \\
\text { weight during } \\
\text { infusion (g) }\end{array}$ & $+24 \pm 0.8$ & $-27 \pm 11.7^{*}$ & $-29 \pm 1.7^{\circ}$ & $+15 \pm 1.6$ & $+35 \pm 1.2$ \\
\hline $\begin{array}{l}\text { Heart weight } \\
\text { (g) }\end{array}$ & $1.08 \pm 0.03$ & $1.06 \pm 0.02$ & $1.06 \pm 0.04$ & $1.13 \pm 0.03$ & $1.03 \pm 0.04$ \\
\hline $\begin{array}{l}\text { Heart (dry/wet } \\
\text { weight ratio) }\end{array}$ & $0.22 \pm 0.01$ & $0.23 \pm 0.01$ & $0.22 \pm 0.01$ & $0.24 \sharp 0.01$ & $0.22 \pm 0.01$ \\
\hline $\begin{array}{l}\text { Heart to body } \\
\text { weight ratio } \\
\left(10^{-9)}\right.\end{array}$ & $3.1 \pm 0.2$ & $3.8 \pm 0.2^{*}$ & $3.7 \pm 0.1^{\mathrm{m}}$ & $3.7 \pm 0.1^{\circ}$ & $2.8 \pm 0.1$ \\
\hline
\end{tabular}

Group $\mathrm{NaCl}$ received $0.9 \% \mathrm{NaCl}$, group Angll received AnglI group Angll+DMSO received Angll and 50\% DMSO, group Anglltdoxa received Angll and doxazosin, group DMSO received $50 \%$ DMSO. Numbers of animals are given between brackets. Values are meantSEM, *) significantly different from the $\mathrm{NaCl}$ group.

\section{Plasma catecholamine levels}

Plasma catecholamine lewels (both norepinephrine and epinephrine) were significantly increased by AngII treatment as compared to $\mathrm{NaCl}$ treatment (figure 6.2). Doxazosin did significantly reduce the Angll induced rise in plasma norepinephrine, but it did not affect the plasma epinephrine levels. 


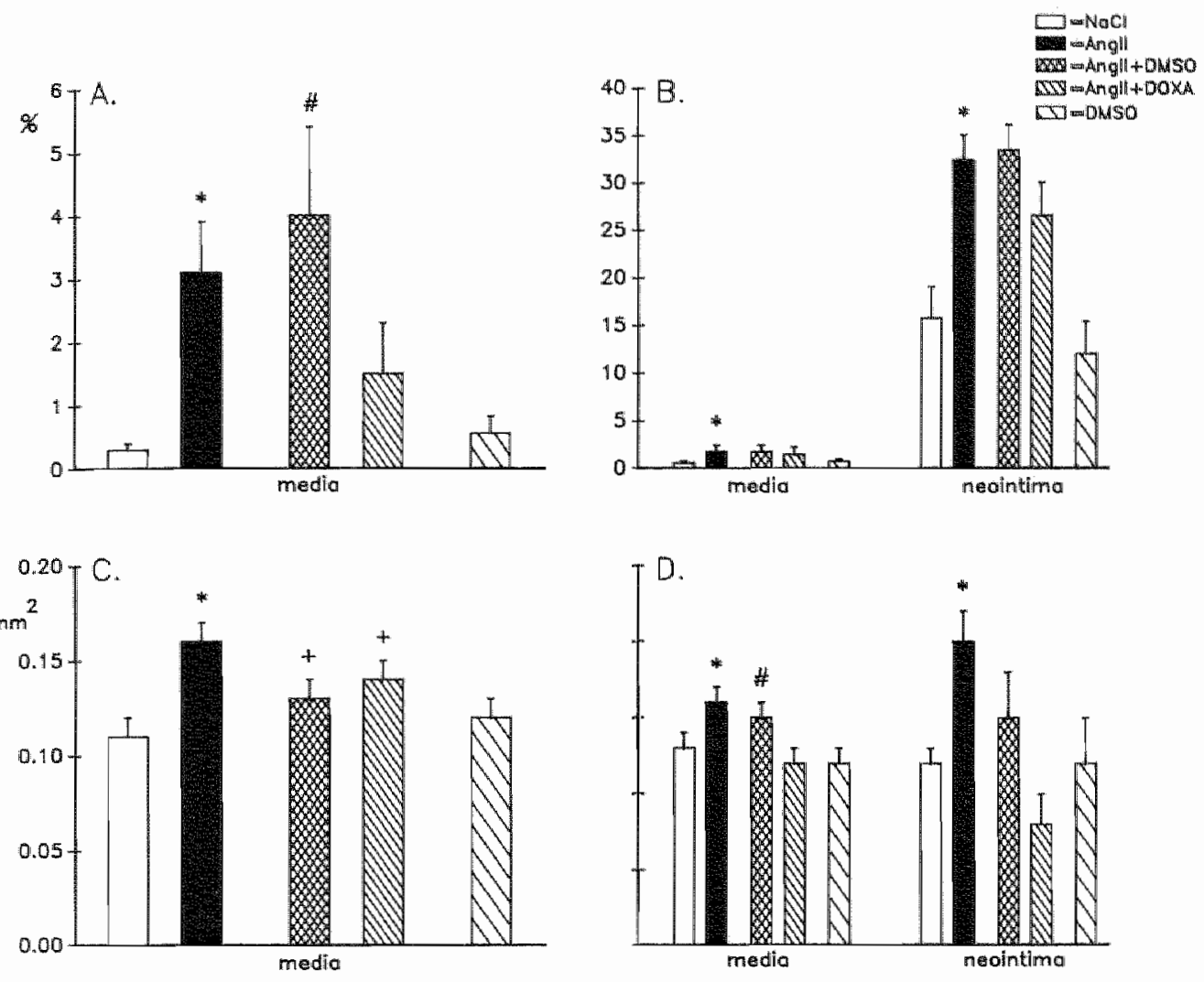

Figure 6.3 The cumblative labeling fraction (\%) in (A) the media of the right carotid artery.

(B) the media (left panel) and neointima (right panel) of the left carotid artery. The cross-sectional area $\left(\mathrm{mm}^{2}\right)$ of (C) the media of the right carotid artery; (D) the media (left panel) and neointima (right panel) of the left carotid artery. Data represent mean $\pm S E M$ *) Signficantly different from the $\mathrm{NaCl}$ group, Hit) significantly different from the Angl1+doxa group, to significantly different from the Angll group.

Effects of AngII and doxazosin on the non-injured right carotid artery: SMC DNA synthesis and CSA

In the media of the right carotid artery of the rats infused with $0.9 \% \mathrm{NaCl}$ the BrdUrd labeling fraction was $0.3 \pm 0.1 \%$ (figure $6.3 \mathrm{~A}$ ). Infusion of Angll significantly increased SMC DNA synthesis to $3.1 \pm 0.8 \%$. The LF of the animals that received both AngIl and doxazosin was significantly reduced from $4.0 \pm 1.4 \%$ in the 
AngII+DMSO group to $1.5 \pm 0.8 \%$ in the AnglI+doxa group. The LF of the DMSO group was $0.6 \pm 0.3 \%$ and not different from the $\mathrm{NaCl}$ group.

The medial cross-sectional areas of the right carotid artery are given in figure $6.3 \mathrm{C}$. Angll infusion significantly increased the CSA from $0.11 \pm 0.01 \mathrm{~mm}^{2}$ in the $\mathrm{NaCl}$ group to $0.16 \pm 0.01 \mathrm{~mm}^{2}$. DMSO infusion reduced the AngII induced increase in CSA; in the Angll+DMSO group the CSA area was $0.13 \pm 0.01 \mathrm{~mm}^{2}$. The CSA of $0.14 \pm 0.01 \mathrm{~mm}^{2}$ in the AngIT+doxa group was not different from the CSA in the AngII+DMSO group. DMSO infusion alone resulted in a CSA of $0.12 \pm 0.01 \mathrm{~mm}^{2}$.

\section{Effects of AngII and doxazosin on the injured left carotid artery: medial and neointimal SMC DNA synthesis and CSA}

Angll infusion increased the LF in the media of the left carotid artery from $0.6 \pm 0.2 \%$ in the $\mathrm{NaCl}$ group to $1.8 \pm 0.7 \%$ (figure $6.3 \mathrm{~B}$, left panel). Infusion of Angll and 50\% DMSO resulted in a similar labeling fraction as AngII infusion alone, i.e. $1.8 \pm 0.7 \%$. The LF of the AngII+doxa group was not different from the LF in the AnglI+DMSO group, i.e. $1.2 \pm 0.8 \%$ vs. $1.8 \pm 0.7 \%$. DMSO infusion alone did not affect the LF $(0.8 \pm 0.2 \%)$; this LF did not differ from the LF in the $\mathrm{NaCl}$ group.

In the neointima, the labeling fraction in the $\mathrm{NaCl}$ group was $15.8 \pm 3.3 \%$ (figure $6.3 \mathrm{~B}$, right panel). AngII infusion doubled the neointimal SMC DNA synthesis to $32.5 \pm 2.6 \%$. DMSO infusion did not affect the Angll induced increase in SMC DNA synthesis, since the LF in the neointima of the AngII+DMSO group was $33.5 \pm 2.7 \%$. Coinfusion of doxazosin did not affect the AngII induced increase in SMC DNA synthesis, the LF in the AngIItdoxa group was $26.6 \pm 3.5 \%$. DMSO infusion resulted in a LF in the neointima of $12.1 \pm 3.4 \%$, which is not different from the $\mathrm{LF}$ in the $\mathrm{NaCl}$ group.

The cross-sectional areas of both left carotid media and neointima (figure 6.3D) were significantly increased by infusion of AngII: the medial CSA increased from $0.13 \pm 0.01 \mathrm{~mm}^{2}$ in the $\mathrm{NaCl}$ group to $0.16 \pm 0.01 \mathrm{~mm}^{2}$ in the AngII treated group, whereas the neointimal cross-sectional area increased from $0.12 \pm 0.01 \mathrm{~mm}^{2}$ to $0.20 \pm 0.02 \mathrm{~mm}^{2}$. DMSO infusion did not affect the Angll induced increase in CSA in both media and neointima of the injured artery $\left(0.15 \pm 0.01\right.$ and $0.15 \pm 0.03 \mathrm{~mm}^{2}$ in the AnglI+DMSO group respectively). Doxazosin reduced the Angll induced increase in CSA in the left carotid media $\left(0.12 \pm 0.01 \mathrm{~mm}^{2}\right)$ and neointima $\left(0.08 \pm 0.02 \mathrm{~mm}^{2}\right)$. DMSO infusion alone resulted in a medial CSA of $0.12 \pm 0.01$ $\mathrm{mm}^{2}$ and a neointimal CSA of $0.12 \pm 0.03 \mathrm{~mm}^{2}$. 


\section{DISCUSSION}

The observations made in this study first of all confirm the results of earlier studies from our and other laboratories that neointimal SMC are more sensitive to the stimulatory effects of AngII on DNA synthesis than medial SMC $(11,12)$. The reduction of the AngII induced increase in DNA synthesis in the media of the noninjured right carotid artery by co-treatment with the $\alpha_{1}$-adrenoreceptor blocker doxazosin confirms our previous result that co-treatment with Angll and another selective $\alpha_{1}$-adrenoreceptor blocker prazosin reduces the Angll induced increase in medial SMC DNA synthesis of the carotid artery (13, chapter 4). The similar effect of both prazosin and doxazosin on medial SMC DNA synthesis indicates that the action of these $\alpha_{1}$-adrenoreceptor antagonists is class specific and due to the blockade of the $\alpha_{1}$-adrenoreceptor.

A new finding in this study is the failure of the $\alpha_{1}$-adrenoreceptor antagonist to reduce the AngII induced increase in SMC DNA synthesis in both the media and the neointima of the injured carotid artery. The failure of the antagonist to lower these replication rates cannot be explained on the basis of a dose problem; doxazosin caused an approximate 100-fold shift in the dose-response curve of phenylephrine, which indicates effective $\alpha_{1}$-adrenoreceptor blockade. Moreover, the drug was effective in lowering DNA synthesis in the non-injured carotid artery in the same animals. Possible $\alpha_{2}$-adrenoreceptor blocking effects of doxazosin are unlikely. Although doxazosin, like other $\alpha_{1}$-adrenoreceptor antagonists, has the ability to block $\alpha_{2}$-adrenoreceptors, data from ligand binding studies and experiments in rabbit pulmonary arteries show that doxazosin is even more selective for $\alpha_{1}$ versus $\alpha_{2}$-adrenoreceptors than prazosin, and has a 600 times higher affinity for $\alpha_{1}$ than $\alpha_{2}$-adrenoreceptors (14).

The lack of the effect of doxazosin in the neointima seems to be in contrast with other studies using $\alpha_{1}$-adrenoreceptor antagonists in the balloon injury model in the rat and rabbit. Prazosin, when adminstered directly atter injury, reduces DNA synthesis in the media (15) and neointimal thickening in the rat carotid artery (7), and both prazosin and doxazosin reduce neointimal thickening in the rabbit abdominal aorta $(8,9)$. The difference in effects of $\alpha_{i}$-adrenoreceptor blockade on the neointima between the data in literature and the results of the present study, may be explained by the difference in the time the treatment was started. In all other studies administration of the antagonist was started immediately after injury which may therefore interfere with medial SMC proliferation, SMC migration and neointimal SMC proliferation. In the present study doxazosin infusion was started from day 14 after injury, when a neointima had already been formed. In this way we were able to dissociate possible effects of $\alpha_{1}$-adrenoreceptor blockade on medial and neointimal SMC DNA synthesis. 
The lack of effect of doxazosin to reduce DNA synthesis in the neointima, cannot be explained by a lower sensitivity of the neointimal SMC to Angll, since these cells were even more sensitive to Angll than medial SMC. Enhanced mitogenic effects of DMSO on the neointima were excluded. There are, however, several other possible explanations. First of all, the neointima may be devoid of $\alpha_{1}$ adrenoreceptors. Although $\alpha_{1}$-adrenoreceptors are present in the non-injured rat carotid artery, there are no data available on the amount and distribution of the $\alpha_{1}$ adrenoreceptor in the neointima. A second possibility is that the neointima has $\alpha_{1}$ adrenoreceptors, but that the $\alpha_{1}$-adrenoreceptor subtype differs between the noninjured media and neointima. Recently, at least $3 \alpha_{1}$-adrenoreceptor subtypes (1620) have been isolated and it is possible that only one of these subtypes is involved in the regulation of SMC DNA synthesis and that the neointima lacks this subtype. It is important to note that neither prazosin, nor doxazosin are $\alpha_{1}$-adrenoreceptor subtype specific, although both drugs are indeed $\alpha_{1}$-adrenoreceptor specific antagonists. Another possibility is that the $\alpha_{1}$-adrenoreceptor is involved in the induction of SMC DNA synthesis by an enhanced activity of the sympathetic nervous system and that only the non-injured media, in contrast to the injured media or the developing neointima possesses sympathetic nerve endings. AngII stimulates the activity of the sympathetic nervous system both centrally and peripherally. Peripherally, there is a stimulation of the Angll receptors on the adrenergic nerve varicosities, inhibition of re-uptake of norepinephrine and increased norepinephrine responsiveness of postjunctional $\alpha_{1}$-adrenoreceptors (2l24). The increase in circulating levels of both epinephrine and norepinephrine during Angll infusion in the present study suggests an increased activity of the sympathetic nervous system. Coinfusion with doxazosin reduced the plasma levels of norepinephrine, but did not reduce the plasma epinephrine levels, indicating that doxazosin does not have a major effect on the secretion of catecholamines from the adrenal glands.

The observation that the $\alpha_{1}$-adrenoreceptor is not involved in the induction of SMC DNA synthesis by Angll in the neointima suggests that Angll mediates DNA synthesis in the neointima via other pathways. The blood pressure during AngII infusion does not seem to be an important contributor to the increase in DNA synthesis, since both doxazosin and prazosin (13) were able to reduce the Angll induced increase in DNA synthesis in the non-injured carotid artery, without lowering the blood pressure increase.

The effects of AngII on neointimal SMC DNA synthesis might be direct and mediated by the Angll receptor (AT-receptor). Autoradiography has shown that $80 \%$ of the $\mathrm{AT}$-receptors in the normal rat thoracic aorta are of the $\mathrm{AT}_{1}$-receptor type and $20 \%$ of the $\mathrm{AT}_{2}$-receptor type (25). The rat aortic neointima 15 days after balloon injury, contains predominantly $\mathrm{AT}_{1}$-receptors (25). In vitro, AngII induced 
increases in protein and DNA synthesis are mediated through the $\mathrm{AT}_{1}$-receptor (26, 27), and in all in vivo studies, but one (28), selective blockade of the AT, -receptor inhibits neointima formation when treatment is started immediately after balloon injury (29-31). Thus, it is reasonable to assume that the AT,-receptor might play a role in the neointimal SMC DNA synthesis induced by Angll, although the involvement of the $\mathrm{AT}_{2}$-receptor or other thus far unknown $\mathrm{AT}$-receptors cannot be excluded.

Angll induced an increase in cross-sectional area in the media of the non-injured right carotid artery and in the media and neointima of the injured left carotid artery. An increase in CSA induced by AngII has previously been demonstrated in the balloon injured rat carotid artery $(11, \llbracket 2)$ and has also been described in other arteries, including the superior mesenteric artery (32) and resistance-sized mesenteric arteries (33). Doxazosin reduced the CSA in the media of the injured left carotid artery, and showed a tendency to affect the neointimal CSA $(p>0.05)$. In the non-injured right carotid artery DMSO, and not doxazosin, reduced the medial CSA. Effects of the vehicle DMSO on CSA have not been described in literature, but few studies exist on the effect of DMSO on vascular smooth muscle cell DNA synthesis in culture, varying between no effect at all and reduction of SMC DNA synthesis (34-36).

The different growth response of medial versus neointimal SMC that are demonstrated in the present study may have important clinical consequences. Treatment with $\alpha_{1}$-adrenoreceptor blockers, or other drugs like $\mathrm{ACE}$ inhibitors and the $\mathrm{AT}_{1}$-receptor antagonist losartan, administered directly after injury reduced neointima formation in the rat and rabbits $(7-9,29,30,37)$. However, the MERCATOR study, a clinical trial, showed that the ACE inhibitor cilazapril was not effective in preventing restenosis after PTCA (38) in an already existing intima. One possible explanation for the different results between the animal and the human studies might be the heterogeneity in the growth response of medial and neointimal cells, since most intervention studies in animals have dealt with the proliferative characteristics of the normal vessel wall. The studies presented here suggest, that quite different results can be obtained if the vessel wall has already formed a neointima. 


\section{REFERENCES}

1. Blaes, N; Boissel, JP: Growh-stimulating effect of catecholamines on rat aortic smooth muscle cells in culture. J Cell physiol 1983;116:167\%172.

2. Yamori, $Y$; Mano, $M$; Nara, $Y$; Horie, $R$ : Catecholamine-induced polyploidization in vascular smooth muscle cells. Circ 1987,75(Suppl.1),192-195.

3. Nakaki, T; Nakayama, $\mathrm{M}$; Yamamoto, S; Kato, R: Alpha 1-adrenergic stimulation and beta 2-adrenergic inhibition of DNA synthesis in vascular smooth musele cells. Mol Pharmacol $1990 ; 37: 30-36$.

4. Bevan, RD: Effect of sympathetic denervation on smooth nuscle cell proliferation in the growing rabbit ear artery. Circ Res 1975;37:14-19.

5. Fronek, $\mathrm{K}$; Bloor, CM; Amiel, D; Chvapil, $\mathrm{M}$ : Effect of long-term sympathectomy on the arterial wall in rabbits and rats. Exp Mol Pathol 1978;28:279-289.

6. Lee, RMKW; Triffgle, CR; Cheung, DWT; Coughlin, MD: Stuctural and functional consequence of necnatal sympathectomy on the blood vessels of spontaneously hypertensive rats. Hyperticusion 1987; 10:328-338.

7. Fingerle, $J$; Sanders, KH; Fotev, $Z$ : Alpha-1 receptor antagonists urapidil and prazosin inhibit neointima formation in rat carotid artery induced by balloon catheter injury. Basic Res Cardiol 1991:86(Suppl. 1):75-81.

8. O'Malley, MK; McDermott, EW; Mehigan, D; O'Higgins, NJ: Role for prazosin in reducing the development of rabbit intimal hyperplasia after endothelial denudation. $\mathrm{Br} d$ Surg $1989 ; 76 ; 936-938$.

9. Vashisht, R; Sian, M; Franks, PJ; O'Malley, MK: Long-term reduction of intimal hyperplasia by the selective alpha-1 adrenergic antagonist doxazosin. $\mathrm{Br} J \mathrm{Surg}$ $1992 ; 79: 1285-1288$,

10. Majesky, MW; Daemen, MJ; Schwartz, SM: Alpha 1-adrenergic stimulation of plateletderived growth factor A-chain gene expression in rat aorta. J Biol Chem 1990;265:10821088.

11. Datemen, MJ; Lombardi, DM; Bosman, FT: Schwartz, SM: Angiotensin II induces smooth muscle cell proliferation in the nomal and injured rat arterial wall. Circ Res 1991;68:450456.

12. Osterrieder, W; Muller, RK; Powell, JS; Clozel, JP; Heft, F; Baumgartner, HR: Role of angiotensin 11 in injury-induced neointima formation in rats. Hypertension $1991: 18(\operatorname{Suppl}, 4): 1160-1164$. 
13. van-Kleef, EM; Smits, MF; De-Mey, JG; Cleutjens, JP; Lombardi, DM; Schwartz, SM; Daemen, MI: Alpha 1-adrenoreceptor blockade reduces the angiotensin 11-induced vascular smooth muscle cell DNA synthesis in the rat thoracic aorta and carotid artery. Circ Res $1992 ; 70: 1122 \cdot 1127$

14. Davey, M: Mechanism of alpha blockade for blood pressure control, Am I Cardiol $1987-59: 18 \mathrm{G}-28 \mathrm{G}$.

15. Jackson, CL; Bush, RC; Bowyer, DE: Inhibitory effect of calcium antagonists on balloon catheter-induced arterial smooth muscle cell proliferation and lesion size. Atherosel $1988 ; 69: 115-122$.

16. Cotechta, S; Schwinn, DA; Randall, RR; Lefkowitz, RJ; Caron, MG; Kobilka, BK: Molecular cloning and expression of the cDNA for the hamster alpha 1 -adrenergic receptor. Proc Natl Acad Sci USA 1988:85:7159-7163.

17. Lomasney, JW; Cotechia, S; Lorenz, W; Leung, WY; Schwinn, DA; Yang.Feng, TL; Brownstein, M; Lefkowitz, RJ; Caron, MG: Molecular cloning and expression of the cDNA for the alpha 1A-adremergic receptor. The gene for which is located on human chromosome 5. J Biol Chem 1991;266:6365-6369.

18. Brumo, JF; Whittaker, J; Song, JF; Berelowitz, M: Molecular cloning and sequencing of a cDNA encoding a human alpha $1 \mathrm{~A}$ adrenergic receptor. Biochem Biophys Res Commun $1991 ; 179: 1485-1490$.

19. Schwinn, DA; Lomasney, JW; Lorenz, W; Szklut, PJ, Fremeau, RT, Jr; Yang-Feng, TL; Caron, MG; Lefkowitz, RJ; Cotecchia, S: Molecular cloning and expression of the cDNA for a novel alpha 1-adrenergic receptor subtype. J Biol Chem 1990;265:8183-8189.

20. Schwin, DA; Page, SO; Middletion, JP; Lorenz, W; Liggett, SB; Yamamoto, K; Lapetina, $\mathbb{E G}$; Caron, MG; Lefkowitz, RJ; Cotechia, S: The alic-adrenergic receptor: characterization of signal transduction pathways and mammalian tissue heterogeneity. Mol Pharmacol $1991 ; 40: 619-626$.

21. Luft, $F C$; Wilcox, CS; Unger, T; Kuhn, R; Demmert, G; Rohmeiss, P; Ganten, D; Steracl, RB: Angiotensin-induced thypertension in the rat. Sympathetio nerve activity and prostaglandins. Hypertension $1989 ; 14: 396-403$.

22. Hitgers, KF; Beelken, R; Rupprecht, G; Reeh, PW; Luft, FC; Mann, JFE: Angiotensin II facilitates sympathetic transmission in rat hind limb circulation. Hypertension 1993;21:322328.

23. Zimmerman, BG: Adrenergic facilitation by angiotensin: does it serve a physiological function. Clin Sci 1981;60:343-348.

24. Zimmerman, BG; Sybertz, EJ; Wong, PC: Interaction between sympathetic and reninangiotensin system. J Hypertens 1984:2:581-587. 
25. Viswanathan, $M$; Stromber, $C$; Selzer, $A_{;}$Saavedra, JM: Balloon angioplasty enhances the expression of angiotensin $\mid 1$ ATI receptors in neointima of rat aonta. I Clin Invest $1992,90: 1707-1712$.

26. Chiu, AT; Roscoe, WA; McCall, D; Timmermans, PBMWM: Angiotensin II-1 receptors mediate both wasoconstrictor and hypertrophic responses in rat aortic smooth muscle cells. Receptor 1991;1:133-140.

27. Timmermans, PBMWM; Chu, AT; Herblin, WF; Wong, PC; Smith, RD: Angiotensin II receptor subtypes. Am J Hypertens 1992;5:406-410.

28. Janiak, P; Pillon, A; Prost, JWF; Villaine, J.P: Role of angiotensin subtype 2 receptor in neointima formation after vascular injury. Hypertension 1992:20:737 745.

29. Laporte, $\mathrm{S}$; Escher, $\mathrm{E}$ : Neointima formation after wascular injury is angiotensin II mediated. Biochem Biophys Res Commun 1992;187:1510-1516.

30. Kauffinan, RF; Bean, IS; Zimmerman, KM; Brown, RF; Steinberg, ML: Losartan, a nonpeptide angiotensin II (ANG II) receptor antagonist, inhibits neointima formation following balloon injury to rat carotid arteries. Life Sci 1991;49:223-228.

31. Farhy, RD; Carretero, OA; Khang-Loon, H; Scicli, AG: Role of kinins and nitric oxide in the effects of angiotensin converting enzyme inhibitors on neointima formation. Circ Res $1993 ; 72: 1202-1210$

32. Griffin, SA; Brown, WC; MacPherson, F; McGrath, JC; Wilson, VG; Korsgaard, N; Mulvany, MI; Lever, AF: Angiotensin II causes vascular hypertrophy in part by a nonpressor mechanism. Hypertension 1991;17:626-635.

33. Boonen, HCM; Daemen, MJAP; Eerdmans, PHA; Fazzi, GE; Van Kleef, EM; Schiffers, PMH; De Mey, JGR: Mesenteric resistance artery changes following vasoconstrictor in fusion in young rats. J Candiovase Pharmacol 1993;22:388-395.

34. Zhao, J; Zhang, CY; Xu, DM; Hyuang, GQ; Xu, YL; Wang, ZY: The antiantherogenic effects of components isolated from pollen typhae. Thromb Res 1990;57:957-966.

35. Layman, DL: Growth inhibitory effects of dimethylsulfoxide and dimethysulfone on vascular smooth muscle and endothelal cells in witro. In Vitro Cell Dev Biol 1987:23:422428.

36. Katsuda, S; Okada, Y; Nakanishi, 1; Tanaka, J: Inhibitory effect of dimethylsulfoxide on the proliferation of cultured smooth muscle cells: relationship to the cytoplasmic microtubules. Exp Mol Pathol 1988:48:48m.58.

37. Powell, IS; Clozel, IP; Muller, RK; Kuhn, H; Hefti, F; Hosang, M; Baumgartner, HR: luhibitors of angiotensinuconverting enzyme prevent myointimal proliferation after vascular injury. Science 1989:245:186-188. 
Chupte* 6

38. Serruys, PW: Does the new angiotensin converting enryme inhibitor cilazapril prevent restenosis after percutaneous transluminal coronary angioplasty? Ciro 1992;86:100-110. 
CHAPTER 7

EFFECTS OF A SHORT TERM INFUSION OF PHENYLEPHRINE OR ANGIOTENSIN II ON SMOOTH MUSCLE CELL DNA SYNTHESIS AND MEDIAL CROSS-SECTIONAL AREA IN YOUNG RATS 


\section{SUMMARY}

6 Weeks old normotensive Wistar Kyoto (WKY) rats were infused for 4 days with pressor doses of either the selective $\alpha_{1}$-agonist phenylephrine or AngII. Concomitanty each rat received BrdUrd to measure SMC DNA synthesis. Infusions were given by s.c. implanted osmotic minipumps. SMC DNA synthesis and cross-sectionat area in the media of five arteries, the thoracic aorta, the left carotid artery, the superior mesenteric, the left renal, and the left femoral artery were compared to those in vessels of age-matched normotensive WKY rats infused with $0.9 \% \mathrm{NaCl}$ In the thoracic aorta 4 day infusion of phenylephrine significantly increased SMC DNA synthesis and medial cross-sectional area, while angiotensin II did not increase SMC DNA synthesis or medial cross-sectional area.

In the carotid, superior mesenteric, renal and femoral artery neither SMC DNA synihesis nor medial cross-sectional areas were changed in response to infusion of phenylephrine or angiotensin II. These dara indicate that in young animals short term infusion of the $\alpha_{r}$-adrenoreceptor agonist phenylephrine can stimulate SMC DNA synthesis, but only in the thoracic aorta.

\section{INTRODUCTION}

In chapter 4 and 5 we have shown that the effects of a 2 week infusion of Angll are not homogeneously distributed along large arteries of the vascular tree. We have also shown that the $\alpha_{1}$-adrenoreceptor is involved in the AngII induced SMC DNA synthesis. To further explore the possible involvement of the $\alpha_{1}$-adrenoreceptor in the effects of AngII on medial SMC DNA synthesis, the $\alpha_{1}$-adrenoreceptor agonist phenylephrine was infused in WKY rats and compared with age-matched WKY rats infused with AngIl. In the present experiment we chose to use young, 6 weeks old animals since it has been shown that SMC DNA synthesis is increased at this age in another model of hypertension, the SHR (1). Moreover, previous 2 weeks infusion studies suggested that medial SMC of young rats are more sensitive to the growth promoting effects of AngII than medial SMC of older rats (2).

\section{MATERIALS AND METHODS}

5 Weeks old male Wistar Kyoto rats (WKY; $n=24$ ) were subdivided into three groups: 1) WKY rats receiving phenylephrine ( $n=8)$; 2) WKY rats receiving Angll $(\mathrm{n}=8)$ and 3) $\mathrm{WKY}$ rats receiving $0.9 \% \mathrm{NaCl}(\mathrm{n}=8)$. The experiment lasted 10 days. Systolic blood pressures were measured by tailcuff plethysmography as described in chapter 2.3. Blood pressures were taken on days $-6,-3,0,2$, and 4 ; day 0 
refers to the day at which infusions were started. Phenylephrine, Angll and $0.90 \%$ $\mathrm{NaCl}$ were infused continuously by s.c. implanted osmotic minipumps (Alzet model 2001) during 4 days. Concomitantly, each rat received BrdUrd $(30 \mathrm{mg} / \mathrm{ml}$ in $0.9 \% \mathrm{NaCl}$ ) by a separate osmotic minipump (Alzet model 2001) implanted s.c. After 4 days of infusion the animals were sacrificed by bleeding from the aorta, under ether anesthesia. Hearts were excised and weighed. The thoracic aorta, the left carotid artery, the superior mesenteric artery, the left renal artery and the left femoral artery were isolated and fixed in $10 \%$ phosphate buffered formalin, routinely processed and embedded in paraffin.

\section{Drug infusion}

Phenylephrine and AngII were dissolved in $0.9 \% \mathrm{NaCl}$ and infused at a rate of 2 $\mathrm{mg} / \mathrm{kg} /$ day and $0.3 \mathrm{mg} / \mathrm{kg} /$ day respectively.

\section{Immunohistochemistry}

$4 \mu \mathrm{m}$ Cross-sections were stained immunohistochemically for BrdU $\mathrm{rd}$ (see chapter 2.5.1). The cumulative BrdUrd labeling fraction LF (\%) and the cross-sectional area of the media were determined (chapter 2.5.2).

\section{RESULTS}

\section{Body and heart weights, systolic blood pressures}

WKY rats infused with $0.9 \% \mathrm{NaCl}$ gained body weight during the 4 days infusion (table 7.1). No increases in body weight were found in the WKY rats treated with phenylephrine or Angll (table 7.1). The absolute heart weight did not differ between the three groups; the relative heart weight (heart weight/body weight) was significantly increased in both the phenylephrine and the Angll group (table 7.1). Before the start of the infusion systolic blood pressures (SBP) (figure 7.1) were not different between the 3 experimental groups. Infusion with phenylephrine caused a blood pressure increase of $30 \mathrm{mmHg}$, whereas infusion with Angll increased the SBP to a much larger extent $(+60 \mathrm{mmHg}$, figure 7.1 , table 7.1$)$.

SMC DNA synthesis in the media of thoracic aorta, carotid, superior mesenteric, renal and femoral artery

In the $\mathrm{NaCl}$ group, SMC DNA synthesis was not different between the thoracic aorta, carotid, superior mesenteric, renal, and femoral artery with a mean SMC labeling fraction of $4.2 \%$ (respectively $4.7 \%, 2.3 \%, 4.1 \%, 6.8 \%$ and $2.9 \%$, figure $7.2 A)$. 
Table 7.1 Effects of phenylephrine and angiotensin II on body and heart weight, systolic blood pressure and hean rate.

\begin{tabular}{|c|c|c|c|}
\hline Groups & $\begin{array}{c}\text { WKY } \mathrm{NaCl} \\
(\mathrm{n}=\mathrm{g})\end{array}$ & $\begin{array}{c}\text { WKY tphe } \\
\qquad(n=8)\end{array}$ & $\begin{array}{c}\text { WK } Y+A n g I \\
(n=8)\end{array}$ \\
\hline $\begin{array}{l}\text { Change in body whight } \\
\text { (g) }\end{array}$ & $+22.3 \pm 0.8$ & $-3.3 \pm 8.3^{*}$ & $+11.3 \pm 3.1^{\circ}$ \\
\hline Heart weight (mg) & $612 \pm 18$ & $706 \pm 48$ & $681 \geq 31$ \\
\hline $\begin{array}{l}\text { Heart to body weight } \\
\left(10^{3}\right)\end{array}$ & $4.0 \pm 0.1$ & $5.6 \pm 0.5^{\circ}$ & $5.0 \pm 0.2^{\circ}$ \\
\hline $\begin{array}{l}\text { Change in systolic } \\
\text { blood pressure } \\
\text { (mmHg) }\end{array}$ & $+6.1 \pm 5.1$ & $+25.9 \pm 7.6^{\circ}$ & $+59.7 \pm 1.6^{\circ}$ \\
\hline $\begin{array}{l}\text { Change in heart rate } \\
\text { (bpon) }\end{array}$ & $-17.2 \pm 8.8$ & $-99.1 \pm 27.8^{*}$ & $-85.4 \pm 14.9^{*}$ \\
\hline
\end{tabular}

Changes in body weight, systolic blood pressure and heart rate are given over the period of infusion. Values are mean $\mathrm{SEM}_{*}^{*}$ ) sigmificantly different from $\mathrm{NaCl}, \mathrm{p}<0,05$.

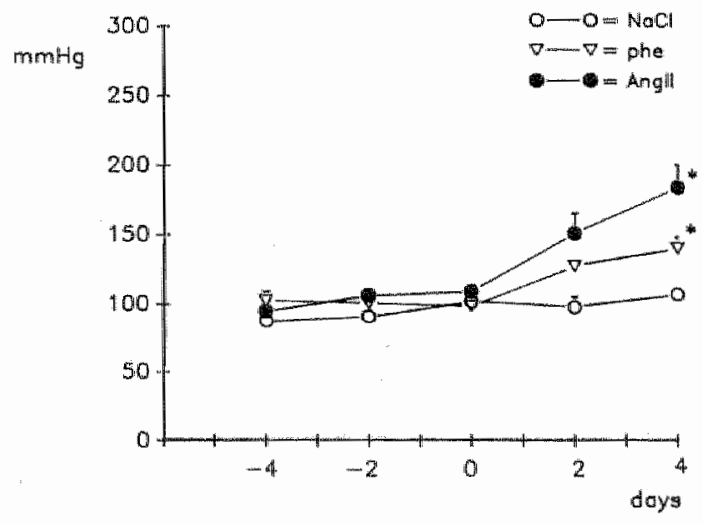

Figure 7.1 The development of systolic blood pressure from 4 days before and during the time of infusion. Wistar Kyoto rats received $0.9 \% \mathrm{NaCl}$, phenylephrine, or angiotensin $\mathrm{II}$. Rats were 5 weeks old at the sart of the experiment. *) Significantly different from $\mathrm{NaCl}$, p 0.05 .

Phenylephrine increased DNA synthesis in the thoracic aorta media to $8.2 \pm 1.6 \%$. In the other arteries the effects of the $\alpha_{1}$-agonist were not statistically significant (figure 7.2A). Infusion of Angll did not increase SMC DNA synthesis in either of the five arterios studied (figure $7.2 \mathrm{~A}$ ). For instance, BrdUrd labeling averaged $6.4 \pm 2.5 \%$ in the thoracic aorta of Angll-intused rats versus $4.7 \pm 0.5 \%$ in the $\mathrm{NaCl}$ group. 

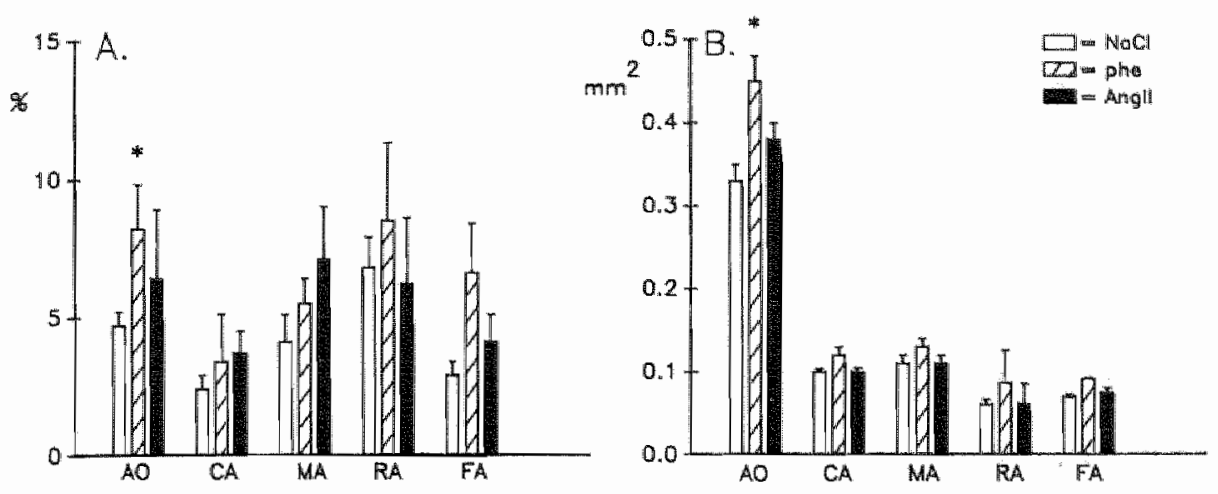

Figure 7.2 (A) The cumulative labeling fractions $(\%)$ and $(B)$ the cross-sectional areas $\left(\mathrm{mm}^{2}\right)$ of the media of the thoracic aorta (AO), the left carotid artery (CA), the superior mesenteric artery (MA), the left renal artery (RA) and the left femoral artery (FA). $\mathrm{NaCl}$, phe, Angll represent 6 weeks old Wistar Kyoto rats receiving a continuous infusion for 4 days of $0.9 \% \mathrm{NaCl}$, pheny. lephrine, angiotensin II respectively. *) significantly different from $\mathrm{NaCl}, \mathrm{p}<0.05$.

Medial cross-sectional area of the thoracic aorta, carotid, superior mesenteric, renal and femoral artery

For the $\mathrm{NaCl}$ infused rats, medial cross-sectional area was $0.33 \pm 0.02 \mathrm{~mm}^{2}, 0.10 \pm$ $0.01 \mathrm{~mm}^{2}, 0.11 \pm 0.02 \mathrm{~mm}^{2}, 0.06 \pm 0.01 \mathrm{~mm}^{2}$ and $0.07 \pm 0.01 \mathrm{~mm}^{2}$ in the thoracic aorta, carotid, superior mesenteric, renal and femoral artery respectively (figure 7.2B). Infusion of phenylephrine significantly increased medial cross-sectional area of the thoracic aorta to $0.45 \pm 0.03 \mathrm{~mm}^{2}$, but did not significantly alter medial crosssectional areas of the other arteries. Infusion of AngIl did not modify the medial cross-sectional areas of either of the five types of artery studied.

\section{DISCUSSION}

This study investigates the effects of a short term infusion of a pressor dose of the specific $\alpha_{1}$-adrenoreceptor agonist phenylephrine on SMC DNA synthesis and medial cross-sectional area in five large elastic arteries of young WKY rats. The data were compared with those obtained from age-matched WKY rats infused with $0.9 \% \mathrm{NaCl}$ or a pressor dose of Angll.

Both phenylephrine and Anglf increased the systolic blood pressure. The increase in systolic blood pressure following AngII infusion was even greater than following phenylephrine infusion. Phenylephrine increased SMC DNA synthesis and 
medial cross-sectional area, but only in the thoracic aorta, whereas Angll did not affect SMC DNA synthesis neither in this artery, nor in the other elastic arteries studied. This indicates that a rise in blood pressure per se is not enough to increase SMC DNA synthesis and that other factors, possibly, but not necessarily, induced by hypertension contribute to the increase in SMC DNA synthesis. One of these factors might be $\alpha_{1}$-adrenoreceptor stimulation.

While the data show that phenylephrine-induced hypertension is accompanied by SMC DNA synthesis, it is unclear whether this increased DNA synthesis is associated with an increase in cell number or ploidy levels. We also do not know whether the effects of phenylephrine effects on aortic SMC DNA synthesis are direct. In vitro data support a possible mitogenic effect of phenylephrine. A number of studies have shown that the catecholamines norepinephrine and epinephrine stimulate DNA synthesis in cultured vascular smooth muscle cells $(3,4)$. Also, phenylephrine induced SMC DNA synthesis can be inhibited by both the nonselective $\alpha$ adrenergic receptor antagonist phentolamine and by the selective $\alpha_{1}$-adrenoreceptor antagonist prazosin, suggesting that the mitogenic effect of catecholamines is mediated through the $\alpha_{1}$-adrenoreceptor (5). Also, observations in vivo have demonstrated that the sympathetic nervous system, and in particular the $\alpha_{1}$-adrenoreceptor, is important in the regulation of vascular smooth muscle growth, especially in young animals (6-8). Surgical denervation at 10 days of age resulted in a thinner rat saphenous artery media and a decrease in smooth muscle cell proportion per crosssectional area (9). At the same time, it is clear that phenylephrine cannot account for the generalized observation of increased vascular SMC DNA synthesis in hypertension, since increased SMC DNA synthesis has been also been described in experimental models of hypertension which are not related to increased sympathetic activity, such as in spontaneously hypertensive or DOCA salt hypertensive rats $(10,11)$.

We and others have observed heterogeneous effects of vasoactive substances on the "growth" of vascular SMC in vivo $(2,12-15)$. Indeed, heterogeneity of growth responses of SMC is a more generalized phenomenon and is recognized in vitro and in vivo and in animal and human studies (12). Although the causes of SMC heterogeneity are still unclear, there are at least two possiblities i.e. the existence of different SMC subtypes with unique growth characteristics (16-18) or a change in the SMC phenotype $(19,20)$. At this point in time we do not whether different SMC subtypes or a change in phenotype, also called phenotypic modulation, contributes to the heterogeneity in the response of the different arteries to phenylephrine observed in the current study. Possible explanations for the observed heterogeneity may be found in the diversity of induction (or inhibition) of other growth regulatory systems like PDGF-A, in heterogeneity of the density of the sympathetic innervation (21) and of the density and subtype of $\alpha$-adrenoreceptors between the arteries studied (22-24). Although it is not known which $\alpha_{1}$-adrenoreceptor subtype 
is involved in the regulation of SMC growth, we know that the distribution of at least the adrenoreceptor subtypes $\alpha_{1 \mathrm{~A}}$ and $\alpha_{1 \mathrm{~B}}$ differs between arteries (25). For instance, contractile responses to norepinephrine appear to be mediated primarily via $\alpha_{1 \mathrm{~B}}$ adrenoreceptors in the rat aorta, whereas they are primarily mediated via $\alpha_{\text {iA }}$ adrenoreceptors in the rat renal artery (25). At present no data are available on the distribution of the third subtype, the $\alpha_{1 \mathrm{C}}$-adrenoreceptor, recently cloned from bovine brain cDNA library (26).

The inability of AngI to increase SMC DNA synthesis in this study seems to be in contrast with previous results from our llaboratory $(2,27$, chapter $4-6)$, where AngII induced significant increases in SMC DNA synthesis in adult rats.

One of the possible explanations for the different effects of AngIl on SMC DNA synthesis might be the angiotensin II receptor (AT receptor) involved. Al least two receptors have been identified so far, and the expression of the AT receptor changes during development. For instance in the rat aorta, a rapid shift in expression of $\mathrm{AT}_{2}$ to $\mathrm{AT}$, receptors has been demonstrated (28). In the thoracic aorta of a 2 weeks old rat $81 \%$ of the $\mathrm{AT}$ receptors are of the $\mathrm{AT}_{2}$ receptor, whereas the $\mathrm{AT}$, receptor is predominantly present $(71 \%)$ in the 8 weeks old rat. Since all known biological effects of AngII are mediated through the AT, receptor (29), one might suggest that the number of $\mathrm{AT}_{1}$ receptor present in investigated elastic arteries of 6 weeks old rats was too low to mediate the growth stimulating effects of Angll.

Another explanation may be that, although AngII was infused at almost comparable infusion rates in the two studies $(0.3 \mathrm{mg} / \mathrm{kg} / \mathrm{day}$ vs $0.5 \mathrm{mg} / \mathrm{kg} / \mathrm{day})$, the peptide was infused for onlly 4 days in the present study in contrast to 2 weeks in the earlier studies $(2,27$, chapter 4-6). 4 Days infusion of AnglI, however, did increase the cross-sectional area of small mesenteric arteries (forth order side branches of superior mesenteric artery (15). So far, we have not investigated the effects of a 2 week infusion of AngII in 6 weeks old rats, but apparently, a shorter infusion time is not enough to increase SMC DNA synthesis. As mentioned above also the age of the rats differed: 6 weeks in this study vs. at least 18 weeks in earlier studies $(2,27)$. Agc-related differences in vascular SMC DNA synthesis have also been found in vitro $(16-18,30-32)$ and may contribute to heterogeneity in the growth response of SMC.

To summarize the data presented in this study show that in 6 weeks old rats a short term infusion of a pressor dose of phenylephrine increases SMC DNA synthesis and medial cross sectional area, but only in the thoracic aorta, whereas angiotensin II infused for the same time period was not effective. The findings illustrate that 1) a blood pressure rise per se does not induce vascular growth, 2) $\alpha_{1}$-adrenoreceptor stimulation can increase DNA synthesis in vivo and 3) SMC growth responses are heterogeneous. 


\section{REFERENCES}

1. De-Mey, JG; Daemen, MS; Boonen, HC; Bosman, FT; Dijkstra, EH; Fazzi, GE; Janssen, GM; Schiffers, PM; Struyker-Boudier, HA; Vrijdag, MJ: In vivo DNA synthesis is not winiformly increased in arterial smooth muscle of young spontaneously hypertensive rats. I Hypertens $1991: 9.695-701$.

2. Daemen, MJ; Lombardi, DM; Bosman, FT; Schwartz, SM: Angiotensin II induces smooth muscle cell prohiferation in the normal and injured rat arterial wall. Circ Res 1991;68:450456.

3. Yamori, $\mathrm{Y}$; Mano, $\mathrm{M}$; Nara, $\mathrm{Y}$; Horie, R: Catecholamine-induced polyploidization in vascular smooth muscle cells. Circ 1987:75(Suppl.I):192-195.

4. Blaes, $N_{*}$ Boissel, JP: Growth-stimulating effect of catecholamines on rat aortic smooth muscle cells in culture. J Cell Physiol 1983;116:167-172.

5. Nakaki, T; Nakayama, M; Yamamoto, S; Kato, R: Alpha 1-adrenergic stimulation and beta 2-adrenergic inllibition of DNA synthesis in vascular smooth muscle cells. Mol Pharmacol $1990 ; 37: 30-36$.

6. Bevan, RD: Effect of sympathetic denervation on smooth muscle cell proliferation in the growing rabbit ear artery. Circ Res 1975;37:14-19.

7. Sadoshima, S; Fujii, K; Yao, H; Ibayashi, S; Fujishima, M: Effect of chronic sympathetic denervation on cerebrovascular hypertrophy during the development of hypertension in rats. Brain Res 1986;379:205-209.

8. Todd, ME; Gowen, B: Arterial wall and smooth muscle cell development in young Wistar rats and the effects of surgical denervation. Circ Res 1991;69:438-446.

9. Safar, ME; Levy, B1; London, GM: Arterial structure in hypertension and the effects of angiotensin converting enzyme inhibition. J Hypertens $\rrbracket 992 ; 10: S 5 \|-\$ 57$.

10. Owens, GK: Influence of blood pressure on development of aortic medial smooth muscle hypertrophy in spontaneously hypertensive rats. Hypertension 1987;9:178-187.

11. Chobanian, AV; Lichtenstein, AH; Schwartz, JH; Hanspal, J; Brecher, P: Effects of deoxycorticosterone/salt hypertension on cell ploidy in rat aortic smooth muscle cells. Ciri 1987; 75(Suppl.1):1102-1106.

12. Daemen, MJAP; De Mey, JGR: Heterogeneity of radial structural changes in arteries. Submitted.

13. Schiffers, PM: Struyker-Boudier, HA; De-Mey, JG: Effects of angiotensin II and anglotensin converting enzyme inhibitors on contractile and growth responses in isolated carotid arteries of the rat. Basic Res Cardiol 1991;86(Suppl.1):83-89. 
14. Mackie, EJ; Scot-Burden, T; Hahn, AW; Ken, F; Bernhardt, J; Regenass; S; Weller; A; Buhler, FR: Expression of tenascin by vascular smooth muscle cells. Alterations in hypertensive rats and stimulation by angiotensin II. Am J Pathol 1992;141:377-388.

15. Boonen, HCM; Daemen, MJAP; Eerdmans, PHA; Fazzi, GE; Van Kleef, EM; Sohiffers, PMH; De Mey, JGR: Mesenteric resistance artery changes following vasoconstrictor infusion in young rats. J Cardiovase Pharmacol $1993 ; 22: 388-395$.

16. Majesky, MW; Giachelli, CM; Reidy, MA; Schwartz, SM: Rat carotid neointimal smooth muscle cells reexpress a developmentally regulated mRNA phenotype during repair of arterial injury. Circ Res 1992;71:759-768.

17. Han, DK; Liau, G: Identification and characterization of developmentally regulated genes in vascular smooth muscle cells. Circ Res 1992;71:711-719.

18. Majesky, MW; Benditt, EP; Schwartz, SM: Expression and developmental control of platelet-derived growth factor A-chain and B-chain/Sis genes in rat aortic smooth muscle cells. Proc Natl Acad Sci USA 1988;85:1524-1528.

19. ChambleymCampbell, JH; Campbell, GR; Ross, R: The smooth muscle cell: in culture. Plyysiol Rev 1979;59:1-61.

20. Schwartz, SM; Campbell, GR; Campbell, JH: Replication of smooth muscle cells in vascular disease. Circ Res 1986;58:427-444.

21. Bevan, JA; Bevan, RD; Duckles, SP: Adrenergic regulation of vascular smooth muscle. In: Bohr, Df; Sombyo, AP; Sparks, HV (edsu): Handbook of Physiology. Bethesda, Md, American Physiological Society, 1980:515-566.

22. Ruffolo, RR; Nichols, AI; Stadel, JM; Hieble, JP: Structure and function of alpha-adrenoceptors. Pharmacol Rev $1991 ; 43: 475-505$.

23. Flavahan, NA; Vanhoutte, PM: $\alpha$ 1-Adrenoceptor subclassification in vascular smooth muscle. TIPS $1986 ; 7 ; 347-349$.

24. Vanhoutte, PM; Verbeuren, TJ; Webb, RC: Local modulation of adrenergic neuroeffector interaction in the blood vessel wall. Physiol Rev 1981;61:151-218.

25. Han, C; Li, J; Minneman, KP: Subtypes of alpha 1 -adrenoceptors in rat blood wessels. Eur J Pharmacol 1990;190:97-104.

26. Schwinn, DA; Lomasney, JW; Lorenz, W; Szklut, PJ; Fremeau, RT, Jr; Yang-Feng, TL; Caron, MG; Lefkowitz, RJ; Cotecchia, S: Molecular cloning and expression of the CDNA for a novel alpha 1-adrenergic receptor subtype. J Biol Chem 1990;265:8183-8189. 
27. varmKleet, EM; Smits, JF; De-Mey, JG; Cleutjens, JP; Lombardi, DM; Schwart, SM; Daemen, MI: Alpha I-adrenoreceptor blockade reduces the angiotensin If-induced vascular smooth muscle cell DNA synthesis in the rat thoracic aorta and carotid artery. Circ Res 1992;70:1122-1127.

28. Viswanathan, $M$; Tsutsumi, $\mathrm{K}$; Correa, FM; Saavedra, $\mathrm{NM}$ : Changes in expression of angiotensin receptor subtypes in the rat aorta during development. Biochem Biophys Res Commun $1991 ; 179: 1361-1367$.

29. Chit, AT; Roscoe, WA; MoCall, D; Timmermans, PBMWM: Angiotensin Il-1 receptors mediate both wasoconstrictor and hypertrophic responses in rat aortic smooth muscle cells. Receptor 1991:1:133-140.

30. Hultgardh-Nilsson, A; Krondahl, U; Querol-Ferrer, $V_{;}$Ringertz, NR: Differences in growth factor response in smooth muscle cells isolated from adult and neonatal rat arteries. Diff 1991;47:99-105.

31. Walker, LN; Bowen-Pope, DF; Ross, $\mathbb{R}$; Reidy, MA: Production of platelet-derived growth factor-like molecules by cultured arterial smooth muscle cells accompanies proliferation after arterial injury. Proc Natl Acad Sci USA 1986;83:7311-7315.

32. Giachelli, CM; Majesky, MW; Schwartz, SM: Developmentally regulated cytochrome P4501A1 expression in cultured rat vascular smooth muscle cells. J Biol Chem $1991 ; 266: 3981-3986$. 
CHAPTER 8

EFFECTS OF A CONTINUOUS PHENYLEPHRINE INFUSION ON VASCULAR SMOOTH MUSCLE CELL DNA SYNTHESIS IN THE BALLOON INIURED RAT CAROTID ARTERY - ROLE OF NITRIC OXIDE 


\section{SUMMARY}

To further invesigate the effects of stimulation of the $\alpha_{1}$-adrenoreceptor on SMC

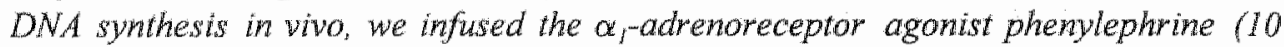
$m \mathrm{~g} / \mathrm{kg} / \mathrm{day}$ ) in balloon injured rats. In another series of experiments, the arginine analogue $N^{B}$-nitro L-arginine methyl ester (L-NAME; I mg/kg/day), an inhibitor of nitric oxide (NO) synthesis, was co-infused with phenylephrine. Infusions were given via s.c. implanted minipumps for 14 days in the $3^{\text {rd }}$ and $4^{\text {th }}$ week after balloon injury of the left carotid artery ( $n=6$ per group). Concomitantly, each rat received BrdUtd in a separate osmotic minipump to measure SMC DNA synthesis. Infusion of phenylephrine did not increase the systolic blood pressure in comparison with the NaCl group. Co-infusion of phenylephrine with L-NAME significantly increased the systolic blood pressure with $37 \pm 5 \mathrm{mmHg}$ in the $3^{\text {rd }}$ week after balloon injury, but the systolic blood decreased towards normotensive levels in the $4^{\text {th }}$ week of infusion. In the media of the non-injured right carotid artery the BrdUrd LF increased from $0.2 \pm 0.1 \%$ in the $\mathrm{NaCl}$ group to respectively $1.2 \pm 0.4 \%$ and $1.3 \pm 0.4 \%$ in the phenylephrine and phenylephrine $+L-N A M E$ group. In both the media and the neointima of the injured left carotid artery, no increases in SMC DNA synthesis were found in response to infusion of either phenylephrine, phemylephrine $+L-N A M E$ or L-NAME Besides, treatment with phenylephrine, phenylephrine $L-N A M E$ or $L-N A M E$ did not affect the cross-sectional areas of the right carotid media, nor of the left carotid media and neointima. These data con-

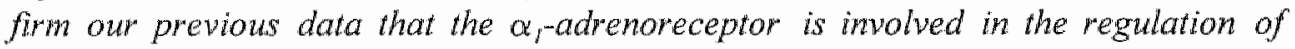
SMC DNA synthesis in the non-injured right carotid media, but not in the medial and neointimal SMC after balloon injury of the left carotid artery. The data further indicate that NO is involved in the control of blood pressure but not in the basal control of SMC DNA synthesis in vivo.

\section{INTRODUCTION}

Previous data presented in this thesis (chapters 4,5 and 6) indicated the involvement of the $\alpha_{1}$-adrenoreceptor in the induction of medial SMC DNA synthesis by Angll. However, it remained unclear, whether the $\alpha_{1}$-adrenoreceptor was involved through a serial or parallel pathway (figure 8.1). Serial stimulation implies that stimulation of the $\alpha_{1}$-adrenoreceptor is a prerequisite for the stimulatory effects of AngII on SMC DNA synthesis and would indicate that the $\alpha_{1}$-adrenoreceptor and not Angll is the control molecule. The parallel pathway implies that both systems are important in the control of SMC DNA synthesis and may act independently. 


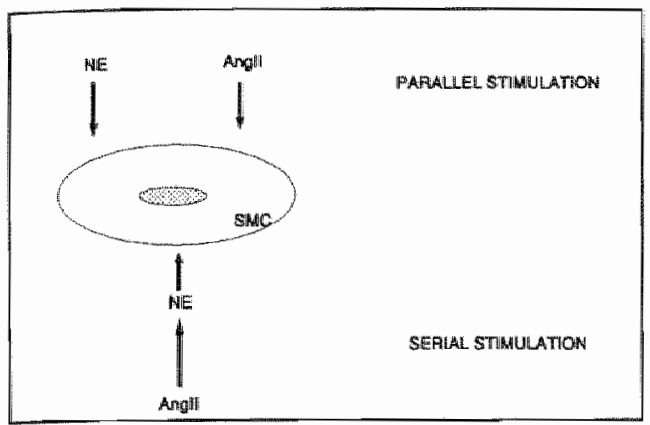

Figure 8.1 Schematic drawing of a model for the involvement of the $\alpha_{1}$-adrenoreceptor in the induction of SMC DNA synthes is by Angll.

Our earlier studies also showed that the effects of $\alpha_{1}$-adrenoreceptor blockade were diverse. While $\alpha_{1}$-adrenoreceptor blockade reduced the induction of medial SMC DNA synthesis in the non-injured rat carotid artery by Angll, no effects were found on the AngII induced medial and neointimal SMC DNA synthesis in the injured carotid artery (chapter 6). Also, in younger animals a short term infusion of phenylephrine stimulated medial SMC DNA synthesis, but only in the thoracic aorta (chapter 7).

In the present study phenylephrine was infused for 2 weeks to investigate the effects of $\alpha_{1}$-adrenoreceptor stimulation on vascular SMC DNA synthesis in vivo. To dissociate possible effects of phenylephrine on the media and the neointima, the the left carotid artery was balloon injured 2 weeks before the start of the phenylephrine infusion.

Phenylephrine stimulates the synthesis of nitric oxide (NO) by SMC in vitro and the release of this vasodilator is thought to be responsible for the labile increase in blood pressure during phenylephrine infusion $(1,2)$. NO also inhibits SMC proliferation in vitro, an effect which is probably mediated through cellular cGMP. cGMP levels are increased by NO and cGMP is a known inhibitor of SMC growth (3-8). The source of NO may be the endothelium $(9,10)$. SMC also contain NO synthase, which releases NO from its precursor arginine (11) and recently it has been suggested that the inducible form of NO synthase is present in the injured rat caroticl. artery (12).

We hypothesized that NO was also involved in the effects of phenylephrine on SMC DNA synthesis and that addition of L-NAME to phenylephrine would increase DNA synthesis after injury. Therefore we added the arginine analogue L-NAME ( $\mathrm{N}^{\mathrm{G}}$-nitro L-arginine methyl ester), an inhibitor of nitric oxide (NO) synthesis to phenylephrine. 


\section{MATERIALS AND METHODS}

\section{Experimental protocol}

24 Male Wistar Kyoto rats (body weight $280-300 \mathrm{~g}$ ) were subjected to an experimental protocol which is similar to the protocol as described in chapter 6 . The experiment lasted five weeks, during which blood pressures were measured by tailcuff plethysmography. In the second week the left common carotid artery was balloon injured. Two weeks after balloon injury, the rats were assigned to one of four groups ( $\mathrm{n}=6$ per group) and infused with either phenylephrine, phenylephrine and L-NAME, L-NAME, or $0.9 \% \mathrm{NaCl}$ by s.c. implanted osmotic minipumps. Concomitantly, all rats received a separate s.c. implanted osmotic minipump with Brdurd. Infusions were continued for 14 days, after which the rats were sacrificed and the vascular bed perfusion fixed with $10 \%$ phosphate buffered formalin. The right and left carotid arteries were isolated and further processed as described in chapter 2.4 .

\section{Drug infusion protocol}

L-Phenylephrine hydrochloride (Sigma, St. Louis, MO) was dissolved in $0.9 \%$ $\mathrm{NaCl}$ and infused at a rate $10 \mathrm{mg} / \mathrm{kg} /$ day (Alzet model 2002). L-NAME (Sigma, St. Louis, $\mathrm{MO}$ ) was dissolved in $0.9 \% \mathrm{NaCl}$ and infused $1 \mathrm{mg} / \mathrm{kg} /$ day (Alzet model 2002). At the same time BrdUrd was dissolved in $0.9 \% \mathrm{NaCl}$ and infused at a rate of $0.8 \mathrm{mg} / \mathrm{kg} /$ day (Alzet model 2002).

\section{Tissue processing}

The left and right carotid artery were processed and cross- sections were stained immunohistochemically with an anti-BrdUrd monoclonal antibody to measure the cumulative BrdUrd labeling fraction (LF) or stained with Lawson to determine the cross-sectional area of the media or the neointima (chapter 2.5.1 and 2.5.2).

\section{RESULTS}

Effects of phenylephrine and L-NAME on systolic blood pressure and body weight

At the start of the experiment all groups had similar systolic blood pressures levels of approximately $130 \mathrm{mmHg}$. The systolic blood pressure was not affected by balloon injury (figure 8.2). Infusion of phenylephrine or L-NAME did not affect the systolic blood pressure as compared to the $\mathrm{NaCl}$ group (figure 8.2). Infusion of phenylephrine and L-NAME significantly increased the SBP in the first week of infusion with approximately $37 \mathrm{mmHg}$ in comparison with the $\mathrm{NaCl}$ group, but in 


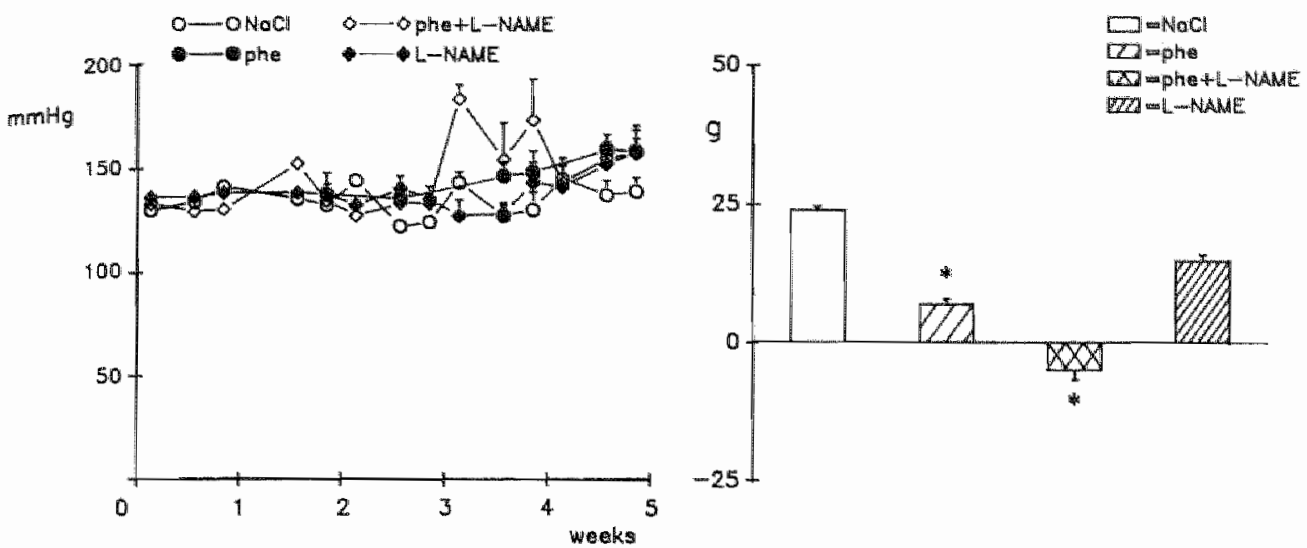

Figure 8.2 The development of the systolic blood pressure during a two weeks of infusion of $0.9 \% \mathrm{NaCl}$, phenylephrine, phenylephrine and L-NAME, and L-NAME two weeks after balloon injury. Data represent mean $\perp S E M,{ }^{*}$ ) Significantly different from $\mathrm{NaCl}_{n} \quad \mathrm{p}<0.05$

Figure 8.3 The changes in bodyweight (g) during the two weeks of infusion of $0.9 \%$ $\mathrm{NaCl}$, phenylephrine, phenylephrine and $\mathrm{L}$ NAME, and L-NAME. Data represent mean $\pm S E M_{*}$ *) Significantly different from $\mathrm{NaCl}, \mathrm{p}<0.05$

the second week of infusion the SBP declined and was not different from the $\mathrm{NaCl}$ group. At the start of the infusions the body weights were comparable. Infusion of phenylephrine, phenylephrine and L-NAME reduced the body weight as compared to infusion with $\mathrm{NaCl}$ or L-NAME alone (figure 8.2).

\section{Effects of phenylephrine and L-NAME on the non-injured right carotid arte-} ry: SMC DNA synthesis and CSA

The SMC DNA synthesis in the media of the right carotid artery, as given by the cumulative BrdUrd LF, was $0.2 \pm 0.1 \%$ in the media of the NaCl group (figure 8.4A). Infusion of phenylephrine significantly increased the LF towards $1.2 \pm 0.4 \%$. Infusion of phenylephrine and L-NAME resulted in a LF of $1.3 \pm 0.4 \%$, which is different from the $\mathrm{LF}$ of $0.2 \pm 0.1 \%$ in the $\mathrm{NaCl}$ group, but not different from the $\mathrm{LF}$ in the phenylephrine group. Infusion of L-NAME alone resulted in a labeling fraction of $0.5 \pm 0.2 \%$, which was not different from the LF of in the NaCl group. The medial cross-sectional area of the right carotid artery was not affected by the infusion of either phenylephrine, L-NAME and phenylephrine or L-NAME alone and was approximately $0.12 \mathrm{~mm}^{2}$ in all groups (figure $8.4 \mathrm{C}$ ) 

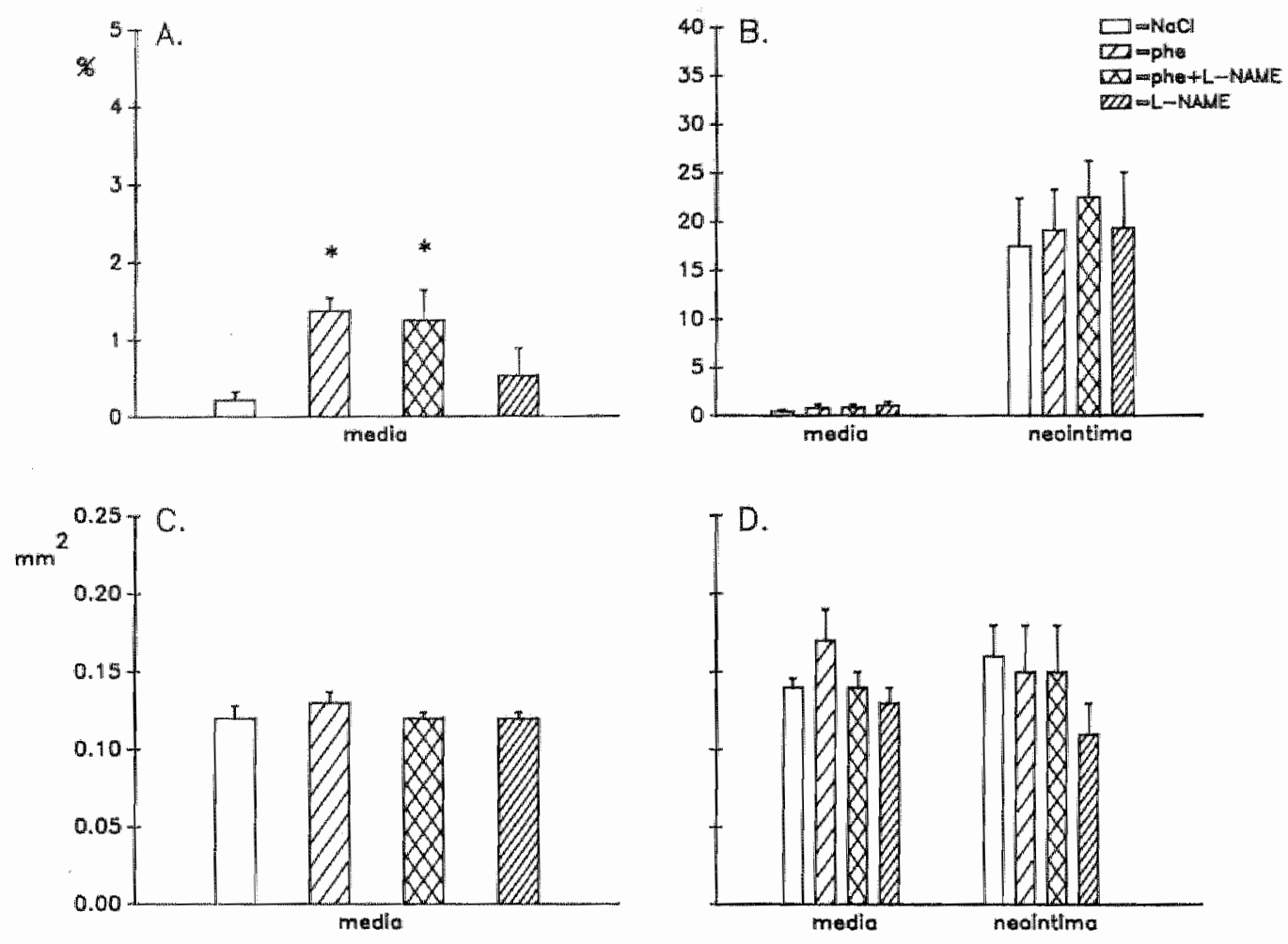

Figure 8.4 (A) The cumulative labeling fraction (\%) in the media of the non-injured right carotid Artery; (B) in the media (left panel) and neointima (right panel) of the left carotid artery. The cross-gectionall area $\left(\mathrm{mmm}^{2}\right)$ of (C) the media of the right carotid artery; (D) the media (left panel) and neointima (right panel) of the left carotid artery. Data represent meantSEM, *) Significantly different from $\mathrm{NaCl}, \mathrm{p}<0.05$

Effects of phenylephrine and L-NAME on the injured left carotid artery: medial and neointimal SMC DNA synthesis and CSA

In the media of the injured left carotid artery the LF in the $\mathrm{NaCl}$ group was $0.5 \pm 0.2 \%$ (figure $8.4 \mathrm{~B}$, left panel). Infusion of phenylephrine did not change the LF which was $0.5 \pm 0.2 \%$. Also infusion of phenylephrine and L-NAME, or infusion of L-NAME alone did not influence SMC DNA synthesis. 
In the neointima, the LF in the $\mathrm{NaCl}$ group was $17.5 \pm 4.9 \%$. Infusion of phenylephrine alone, or phenylephrine and L-NAME did not affect the LF, which were respectively $19.1 \pm 4.1 \%$ and $22.5 \pm 8.2 \%$ (figure $8.4 \mathrm{~B}$, right panel). Also, in the $\mathrm{L}$ NAME infused rats there was no change in neointimal LF, $19.3 \pm 5.6 \%$, as compared to the $\mathrm{NaCl}$ group.

The cross-sectional areas of the left carotid media did not differ between the four groups (figure $8.4 \mathrm{D}$, right panel) and were approximately $0.12 \mathrm{~mm}^{2}$.

Also the CSA of the left carotid neointima was not different between the groups (figure 8.4D, left panel).

\section{DISCUSSION}

Although many studies, using either sympatholytic agents, surgical or chemical sympathectomy or adrenoreceptor antagonists (13-18, chapters 4-6), indicate that the sympathetic nervous systen, and especcially the $\alpha_{1}$-adrenoreceptor, is involved in the regulation of SMC DNA synthesis there are only a few studies available on the effects of adrenergic agonists on SMC DNA synthesis. In vitro, stimulation of the $\alpha_{1}$-adrenergic receptor induces SMC DNA synthesis (19-21). In vivo, a single injection of phenylephrine transiently increases PDGF-A mRNA expression, without stimulating SMC DNA synthesis. The present study shows that $\alpha_{1}$-adrenoreceptor stimulation by phenylephrine can stimulate vascular SMC DNA synthesis, but the effects are heterogeneous. While a two week infusion of the agonist stimulated SMC DNA synthesis in the media of the non-injured carotid artery it had no effect on the medial or neointimal SMC DNA synthesis after injury. These results are in agreement with preliminary findings from De Blois et al (De Blois, personal communication), who found similar effects of phenylephrine in the same model, but with higher doses of the agonist (i.e. $25 \mathrm{mg} / \mathrm{kg} / \mathrm{day}$ ). The data are also in agreement with our earlier observations (22, chapters 4-6) on the involvement of the $\alpha_{1}$-adrenoceptor in the AngII stimulated SMC DNA synthesis in the non-injured carotid media. From those studies it remained unclear, whether the $\alpha_{1}$-adrenoreceptor was involved in a serial or parallel pathway (figure 8.1). The stimulatory effect of phenylephrine on the medial SMC DNA synthesis in the carotid artery indicates at least the possibility of a serial pathway, although it does not exclude a parallel pathway.

The failure of phenylephrine to stimulate SMC DNA synthesis in the injured carotid media and neointima supports our findings on the lack of effect of the $\alpha_{1}$-adrenoreceptor antagonist doxazosin in these same vessel segments (chapter 6). One possible explanation for the observed heterogeneity in the effect of $\alpha_{1}$-adrenoreceptor stimulation on medial and neointimal SMC DNA synthesis is that the injured 
but not the non-injured vessel wall lacks $\alpha_{n}$-adrenoreceptors. Although it is known that the non-injured carotid artery of a rat has $\alpha_{1}$-adrenoreceptors (both subtypes $\alpha_{1 \mathrm{~A}}$ and $\left.\alpha_{13}\right)$, we do not know the amount, distribution and subtype of $\alpha_{1}$-adrenoreceptors in the injured carotid artery. We also do not know which $\alpha_{1}$-adrenoreceptor mediates vascular SMC DNA synthesis. It is, however, possible that injury induces a shift in the $\alpha_{1}$-adrenoreceptor subtype, and that the non-injured media, but not the injured vessel wail has the subtype that mediates SMC DNA synthesis. Another possibility is that the injured vessel wall has no sympathetic nerve endings. It is known that the non-injured carotid artery of an adult rat has a limited sympathetic innervation $(23,24)$, but no data are available on the innervation of the injured vessel wall.

Chronic administration of an inhibitor of nitric oxide synthesis, L-NAME, to normotensive rats increases the blood pressure in a dose-dependent way (25). High doses $(60-70 \mathrm{mg} / \mathrm{kg} /$ day) of L-NAME during 4-6 weeks increased the blood pressure with $60 \mathrm{mmHg}$ (26), whereas doses of $3-10 \mathrm{mg} / \mathrm{kg} /$ day increase the systolic blood pressure with $15-40 \mathrm{mmHg}(25,27,28)$, and the dose of $1 \mathrm{mg} / \mathrm{kg} /$ day used in the present study had no effect on blood pressure, which is in agreement with recent findings reported by Farhy et al. (29), who used a dose of $1.44 \mathrm{mg} / \mathrm{kg} / \mathrm{day}$. Although we observed no significant increase in systolic blood pressure by two weeks infusion of phenylephrine, an instable increase in blood pressure is reported to be a characteristic of long-term infusions of catecholamines. Intravenous infusion of norepinephrine ( $1 \mathrm{mg} / \mathrm{kg} / \mathrm{day}$ ) in rats produces a labile form of hypertension, in which periods of normotension are followed by rapid outbursts of hypertension (30). Other studies have also reported a variable effect of chronic norepinephrine infusions $(31,32)$ on blood pressure. The release of the vasodilator nitric oxide is thought to be responsible for this labile increase in blood pressure during phenylephrine infusion (1). Whereas addition of L-NAME to phenylephrine increased the systolic blood pressure, it did not affect the phenylephrine induced SMC DNA synthesis in non-injured carotid media and had no effect on the medial cross-sectional area. Addition of L-NAME to phenylephrine, or L-NAME alone had no effects on the SMC DNA synthesis or cross-sectional area in the media and neointima of the injured carotid artery, indicating 1) a dissociation between the effect on blood pressure and on SMC DNA synthesis and cross-sectional area and 2) that the lack of effect of phenylephrine on medial and SMC DNA synthesis cannot be explained by possible inhibitory effects of $\mathrm{NO}$.

The failure of L-NAME to affect these parameters could be a dose problem, since only one dose was used. This is however unlikely, since a comparable dose of the drug was effective in blocking the inhibition of neointima formation by the ACE 
inhibitor ramipril in the rat carotid artery (29), whereas the drug did not affect the neointimal cross-sectional area, when infused without the ACE inhibitor.

A dissociation between drug effects on SMC DNA synthesis and blood pressure has also been demonstrated in previous chapters (chapters 4-6), in which $\alpha_{i}$-adrenoreceptor blockade by either prazosin or doxazosin reduced the AngIl induced increase in SMC DNA synthesis, whereas it did not affect the AngII induced increase in systolic blood pressure. Also, other authors (33-35) have demonstrated changes in SMC DNA synthesis that cannot be explained by a change in blood pressure. For example, in vessel segments protected from a blood pressure increase induced by aortic coarctation an increased SMC DNA synthesis has been demonstrated (35).

In the present study, NO synthase inhibition by L-NAME infusion alone did not affect SMC DNA synthesis, nor did it influence the heterogeneous effects of phenylephrine on SMC DNA synthesis. In a recent study by Farhy et al. (29) the role of $N O$ was studied in the effects of ACE inhibition on neointima formation.

Whereas NO synthase inhibition by L-NAME infusion $(1.44 \mathrm{mg} / \mathrm{kg} /$ day $)$ did not reduce the neointimal area in saline treated rats, it signilicantly reversed the reduction in neointimal area in rats treated with the ACE inhibitor ramipril, suggesting an interaction between $\mathrm{ACE}$ inhibition and the induction of NO, exerting antiproliferative effects on SMC (3-5). This indicates that although NO does not seem to be involved in the regulation of the basal SMC proliferation in the media and neointima after injury, it may play a role in the inhibition of SMC growth by kinins in this model.

To summarize, the experiments presented in this study show that a continuous infusion of the $\alpha_{1}$-adrenoreceptor agonist phenylephrine induced SMC DNA synthesis in the media of the non-injured, but not in the media and neointima of the injured rat carotid artery. Furthermore it was shown that although NO is involved in the regulation of the blood pressure during phenylephrine infusion, it is not involved in the basal regulation of SMC DNA synthesis after injury or in the phenylephrine induced SMC DNA synthesis. Also the lack of effect of phenylephrine on neointimal SMC DNA synthesis cannot be explained by possible inhibitory effects of $\mathrm{NO}$. 


\section{REFERENCES}

1. Pegoraro, $A$; Carretero, OA; Sigmon, DH; Beierwaltes, WH: Sympathetic modulation of endothelium-derived relaxing factor. Hypertension 1992;19:643-647.

2. Samsell, L; Engels, $K_{*}$ Qiu, $C$; Baylis, $C$ : Combined angiotensin type 1 receptor (ATI) blockade with losartan (L) and all-adrenoceptor blockade with prazosin (P) normalize blood pressure in chronic endothelial dervived relaxing factor (EDRF) blockade induced hypertension. The American Society o Nephrology, 25th Annual Meeting 1992. Abstract.

3. OConnor, $\mathrm{KF}$; Knowles, $\mathrm{RG}$; Patel, $\mathrm{KD}$ : Nitrovasodilators have proliferative as well as antiproliferative effects. J Cardiovasc Pharmacol 1991;17 (Suppl.3):\$100-\$103.

4. Assender, JW; Southgate, KM; Newby, AC: Does nitric oxide inhibit smooth muscle proliferation? J Cardiovase Pharmacol 1991;17 (Suppl.3):S104-S107.

5. Garg, UC; Hassid, A: Nitric oxide-generating wasodilators and 8-bromo-cyclic guanosine monophosphate inhibit mitogenesis and proliferation of cultured rat vascular smooth muscle cells. IClin Invest 1989;83:17744 1777 .

6. Itoh, H; Pratt, RE; Dzau, WI: Interaction of atrial natriuretic polypeptide and angiotensin II on protooncogene expression and vascular cell growth. Biochem Biophys Res Commun $1991: 176: 1601-1609$

7. Itoh, H; Pratt, RE; Dzau, VJ: Atrial natriuretic polypeptide inhibits hypertrophy of vascular smooth minsucle cells. J Clin Invest 1990;86:1690m1697.

8. Johnson, A; Lemioglu, F; Garg, UC; Morgan-Boyd, R; Hassid, A: A novel biological effect of atrial natriuretic hormone: Inhibition of mesangial cell proliferation. Biochem Biophys Res Commun 1988; 152:893-897.

9. Palmer, RM; Ashton, DS; Moncada, S: Vascular endothelial cells synthesize nitric oxide From L-arginine. Nature 1988-333,664-666.

10. Palmer, RMJ; Ferridge, $\mathbf{A G}$; Moncada, S: Nitric oxide release accounts for the biological activity of endodethelium-derived relaxing factor. Nature 1987,327:524-526.

11. Berk, BC; Vekshtein, V; Gordon, HM; Tsuda, T: Angiotensin II-stimulated protein synthesis in cultured vascular smooth muscle cells. Hypertension 1989;13:305 -314.

12. Joly, GA; Schini, VB; Vanhoute, PM: Balloon injury and interleukin-1 beta induce nitric oxide synthase activity in rat carotid arteries. Cire Res 1992;71:331-338.

13. Bevan, RD. Effect of sympathetic denervation on smooth muscle cell proliferation in the growing rabbit ear artery. Circ Res 1975;37:14-19. 
14. Lee, RMKW; Trifgle, CR; Cheung, DWT; Coughlin, MD: Stuctural and functional consequence of neonatal sympathectomy on the blood vessels of spontaneously hypertensive rats. Hypertension 1987;10:328-338.

15. O'Malley, MK; McDernott, EW; Mehigan, D; O'Higgins, NJ: Role for prazosin in reducing the development of rabbit intimal hyperplasia after endothelial denudation. Br J Surg $1989 ; 76: 936-938$.

16. Vashisht, R; Sian, M; Franks, PJ; OMalley, MK: Long-term reduction of intimal hyperplasia by the selective alpha- I adrenergic antagonist doxazosin. $\mathrm{Br}$ ISurg 1992;79:12851288 .

17. Fingerle, J; Sanders, KH; Fotev, Z: Alpha-1 receptor antagonists urapidil and prazosin inhibit neointima formation in rat carotid antery induced by balloon catheter injury. Basic Res Cardiol 1991;86(Suppl.1):75-81.

18. van-Kleef, EM; Smits, JF; De-Mey, JG; Cleutjens, JP; Lombardi, DM; Schwartz, SM; Daemen, MJ: Alpha I-adrenoreceptor blockade reduces the angiotensin II-induced vaseular smooth muscle cell DNA synthesis in the rat thoracic aorta and carotid artery. Circ Res 1992;70:1122:1127.

19. Blaes, N; Boissel, JP: Growth-stimulating effect of catecholamines on rat aortic smooth muscle cells in culture. J Cell Physiol 1983;116:167-172.

20. Yamori, $Y$; Mano, $M$; Nara, $Y$; Horie, $\mathbb{R}$ : Catecholamine-induced polyploidization in vascular smooth muscle cells. Circ 1987,75(Suppl.1):192-195.

21. Nakaki, T; Nakayama, $M$; Yamamoto, S; Kato, $R$ : Alpha 1-adrenergic stimulation and beta 2-adrenergic inhibition of DNA synthesis in vascular smooth muscle cells. Mol Plyarmacol 1990;37:30-36.

22. Daemen, MJ; Lombardi, DM: Bosman, FT; Schwartz, SM: Angiotensin If induces smooth muscle cell proliferation in the normal and injured rat arterial wall. Circ Res 1991;68:450456.

23. Bevan, JA; Bevan, RD; Duckles, $\mathrm{SP}^{3}$ Adrenergic regulation of vascular smooth muscle. In: Bolu, DF; Sombyo, AP; Sparks, HV (eds.): Handbook of Physiology. Bethesda, Md, American Physiological Society, 1980:515-566.

24. Nilsson, $H$; Goldstein, $M$; Nilsson, $O$ : Adrenergic innervation and neurogenic response in large and small arteries and veins from the rat. Acta Physiol Scand 1986;126:121-133.

25. Arnal, JF; Warin, L; Michel, JB: Determinants of aortic cyclic guanosine monophosphate in hypertension induced by chronic inhibition of nitric oxide synthase. "Clin Invest $1992 ; 90: 647-652$.

26. Ribeiro, MO; Antunes, $\mathrm{E}$; de-Nucci, G; Lovisolo, SM; Zatz, R: Chronic inhitition of nitric oxide synthesis. A new model of arterial hypertension. Hypertension 1992;20:298-303. 
27. Baylis, $C$; Mitruka, B; Deng. A: Chronic blockade of ritric oxide synthesis in the rat produces systemic hypertension and glomerular damage. J Clin Invest 1992;90:278-281.

28. Jover, $B$; Nafrialdi, A; Herizi, A; Mimran, A: Angiotensin in hypertension is assaciated with chronic inhibition of the nitric oxide synthesis. Third International Symposium on ACE inhibition 1993; 3B3. Abstract.

29. Farty, RD; Carretero, OA; Khang-Loon, $H$; Scicli, $A G$ : Role of kinins and nitric oxide in the effects of angiotensin converting enryme imhibitors on neointima formation. Circ Res $1993 ; 72: 1202-1210$.

30. Kleinjans, J; Kasbergen, C; Vervoort-Peters, L; Smits, J; Struyker-Boudier, HAJ: Chronic intravenous infusion of noradrenaline produces labile hypertension in conscious rats. Life Sei $1981 ; 29: 509-514$.

31. Hall, JE; Mizelle, HL; Woods, LL; Montani, JP: Pressure matriuresis and control of arterial pressure during chronic norepinephrine infusion. J Hypertens 1988;6:723-731.

32. King, BD; Sack, $\mathrm{K}_{;}$Kichuk, MR; Hintze, TH: Absence of hypertension despite chronic marked elevations in plasma norepinephrine in conscious dogs. Hypertension 1987,9.582590.

33. Owens, GK; Reidy, MA: Hyperplastic growth response of vascular smooth muscle cells following induction of acute hypertension in rats by aortic coarctation. Circ Res $1985 ; 57: 695-705$.

34. Owens, GK: Influence of blood pressure on development of aortic medial smooth muscle hypertrophy in spontaneously thypertensive rats. Hypertension 1987;9:178-187.

35. Plunkett, WC; Overbeck, HW: lncreased arteriolar wall to lumen ratio in a normotensive vascular bed in coarctation hypertension. Am J Physiol 1985;249:-H849-H866. 
CHAPTER 9

EFFECTS OF ANGIOTENSIN II ON ELASTIN AND COLLAGEN MRNA AND PROTEIN CONTENTS IN THE BALLOON INJURED RAT CAROTID ARTERY 


\section{SUMMARY}

Either AngII $(n=5)$ or $0.9 \% \mathrm{NaCl}(n=5)$ were administered to male Wistar Kyoto rats 2 weeks after balloon injury of the left carotid artery. Infusions were continued for 2 weeks. At the end of the infusion period, the cross-sectional areas of the media and the neointima were determined morphometrically. Elastin, collagen I and III mRNA were localized by in situ hybridization. The protein concentrations and amounts of elastin and collagen were quantified by morphometric and biochemical analysis.

Angll significantly increased the cross-sectional area of the media and neointima. The in situ hybridization studies suggested a higher expression of elastin mRNA in the lefi carotid neoimtima of the AngII group than in the NaCl group. Medial SMCs also expressed elastin mRNA. No differences were, however, found in the expression patterns between the media of the left and right carotid artery, and AngII had no effect on elastin mRNA expression in the media. The same pattern was found for the expression of collagen $\alpha_{f}(l)$ and $\alpha_{i}(I I I)$ mRNAs: in situ hybridization showed a higher expression in the left carotid neointima of the Angll group than in the NaCl group. Both left and right carotid medial SMCs expressed both collagen $\alpha_{f}(I)$ and $\alpha_{j}(I I I) m R N A$, but to a much lower extent than in the neointima. In the media, no effects of AngII infusion on collagen mRNA expression could be detected at both locations.

AngIl infusion did not change the total amount of elastin protein in the media or neointima. The total amount of collagen protein was increased, but only in the neointima.

Thus, these data indicate that two weeks infusion with AngII does not have major effects on the expression of elastin and collagen $\alpha_{i}(I)$ and $\alpha_{i}(I I I)$ mRNAs, and total amount of elastin and collagen protein in the rat carotid media. However, AngII infusion increases the expression of both elastin and collagen $\alpha_{i}(I)$ and $\alpha_{7}(I I)$ $m R N A s$, and the total amount of collagen protein in the neointima.

\section{INTRODUCTION}

The media of a normal elastic artery contains not only SMC but also a large amount of extracellular matrix material which may occupy up to $70 \%$ of its medial volume (1). Also the neointima, formed after balloon injury, contains a large amount of extracelluar matrix (2-7) and excessive deposition of extracellular matrix proteins in the neointima may contribute to restenosis after PTCA (8-10). The composition of the extracellular matrix and the distribution of extracellular matrix components in the media and probably also in the neointima are important denominators of the contractile responses of the vessel wall $(2,11-14)$. Moreover, 
it becomes evident that the composition of the extracellular matrix in the vessel wall is not static and can rapidly change during altered hemodynamic or neurohumoral conditions (15-18). Also, known "snooth muscle coll growth regulatory molecules", as Angh (19-21, chapters 4-6), affect the metabolism of extracellular matrix proteins, which in torn may affect smooth muscle cell migration and proliferation $(12,22-24)$. AngL, when administered to SMC cultured in serum-free medium, induces the expression of the mRNAs of collagen types 1 , III, and $V$, fibronectin and tenascin and increases the amount of the respective proteins (25-29). In vivo, rats which were made hypertensive by subcutancous infusion of Angll $(0.7 \mathrm{mg} / \mathrm{kg} / \mathrm{day})$ showed an increased expression of libronectin mRNA in the thoracic aorta (30). Indirect evidence for a stimulatory role of Angll on the metabolism of elastin and collagen comes from a study in which chronic treatment of growing rats with the ACE inhibitor enalapril reduced the absolute amounts of elastin and collagen in large arteries (31), such as the carotid artery. The effects of AngII on the composition of the extracellular matrix in the media and neointima after balloon injury are not known.

In the current study the effects of Angll on two extracellular matrix proteins, elastin and collagen, were investigated.

\section{MATERIALS AND METHODS}

The left carotid artery of 10 Male Wistar Kyoto rats (body weight $280-300 \mathrm{~g}$ ) was balloon injured (chapter 2.2). Two weeks after balloon injury, the animals received a s.c. implanted osmotic minipump (Alzet model 2002), containing either Angll $(0.5 \mathrm{mg} / \mathrm{kg} / \mathrm{day} ; \mathrm{n}=5)$ or $0.9 \% \mathrm{NaCl}(\mathrm{n}=5)$.

\section{Tissue processing}

After two weeks of infusion, the rats were killed in deep cther anesthesia. $2 \mathrm{~cm}$ Segments of the left and right carotid artery (figure 9.1) were excised for biochemical analysis of collagen and clastin protein content. Caudal to this segment, 2 additional segments (2 $\mathrm{mm}$ each) were excised. One of these latter segments was incubated in cold $4 \%$ paraformaldehyde and further processed for in situ hybridization studies, the other one was routinely processed and embedded in paraffin (chapter 2.4). $4 \mu \mathrm{m}$ Cross-sections were cut from the parafin segment and stained for elastin and collagen (chapter 2.5.2). 


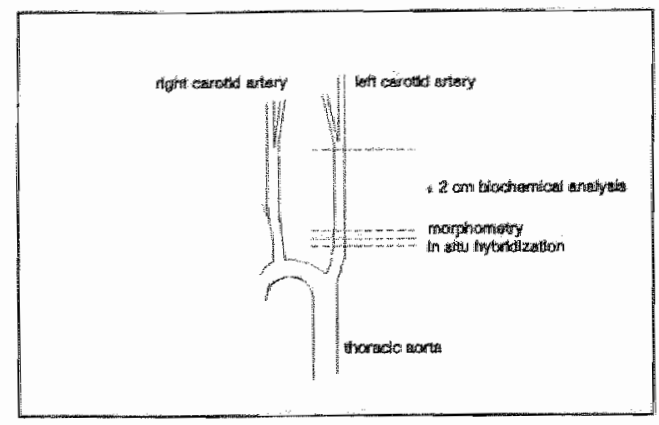

Figure 9.1 Schematic drawing of a carotid artery, indicating the segments used for biochemical and morphometric analysis.

\section{In situ hybridization}

The transcription of the rat elastin, rat collagen $\alpha_{1}(\mathrm{I})$ and rat collagen $\alpha_{1}$ (III) cDNAs and the in situ hybridizations were performed according the protocols described in chapter 2.5.3. The exposure times were 1-2 weeks for all probes.

Sections of the right and the left carotid artery of each animal $(n=3$ per group) were hybridized. The hybridization studies were repeated twice. A section from a rat carotid artery 14 days after balloon injury hybridized with the respective probes served as a positive control (32).

\section{Measurement of the elastin and collagen protein area per cross-section}

For the measurement of the relative elastin area, i.e. the percentage of the total measured area that stained positive for elastin, paraffin cross-sections were stained with Lawson solution. For the measurement of the relative collagen area, i.e. the percentage of the total measured area that stained positive for collagen, paraffin cross-sections were stained with $0.1 \%$ sirius red in saturated aqueous picric acid. All sections were stained in one session. The relative elastin or collagen area was determined using an image analyzer, Quantimet 750 (Leitz, Cambridge) (chapter 2.5.2). The relative elastin (or collagen) area per cross-section was calculated as the sum of the elastin (or collagen) positive areas (x100) divided by the sum of the total tissue area and was expressed as percentage (\%). One cross-section per vessel was used.

The total elastin (or collagen) positive area (media or neointima) was calculated by multiplying the relative elastin (or collagen) area and the cross-sectional area of the same section and was expressed as $\mathrm{mm}^{2}$. Lawson stained sections were used for measurement of the cross-sectional area $\left(\mathrm{mm}^{2}\right)$ of the media or neointima.

\section{Biochemical assay for the quantification of elastin and collagen protein amount}

The hydroxyproline amount of the media and the neointima was used to determine the collagen and elastin amount $(33,34)$. From the $2 \mathrm{~cm}$ carotid artery segments, the wet weight was deternined. Subsequently, the media was stripped away from 
the adventitia and the neointima by use of a microscope and fine forceps. Care was taken to sample all media and neointima. The adventitia was not studied. Artery segments from 2-3 animals of the same treatment group ( $\mathrm{Angll}$ or $\mathrm{NaCl}$ ) had to be pooled. Neointima and media were processed separately for determination of the dry weight and for the hydroxyproline assay (chapter 2.6.2).

The relative amount of insoluble elastin (the elastin concentration) was determined by the amount of hydroxyproline in the cyanogen bromide residue and was expressed as hydroxyproline amount per mg dry weight. The total amount of elastin was calculated by multiplying the elastin concentration and the dry weight. The relative collagen amount (collagen concentration) was calculated from the sum of the hydroxyproline amounts in the SDS and $\mathrm{CNBr}$ extracts and expressed as hydroxyproline amount per mg dry weight. The absolute amount of collagen was calculated by multiplying the collagen concentration and the dry weight.

\section{RESULTS}

\section{In situ hybridization}

Medial and neointimal SMC expressed elastin mRNA and the expression of elastin mRNA was higher in the neointima than in the media. Angll had no effects on the elastin mRNA expression in the media, but increased the elastin mRNA expression in the neointima (figure 9.2).

Medial SMC of both the left and the right carotid artery expressed collagen type $\mathbb{1}$ and III mRNA, but the expression levels were much lower than in the neointima (figure 9.3). There were no differences in expression levels between collagen type $I$ and III. Angll increased the amounts of collagen mRNA in the neointima, but not in the media (figure 9.3).

\section{Changes in cross-sectional area and weight following Angll}

Angll infusion significantly increased the medial cross sectional area of the right carotid artery from $0.11 \pm 0.01 \mathrm{~mm}^{2}$ to $0.16 \pm 0.01 \mathrm{~mm}^{2}$ (table 9.1). Also the crosssectional areas of the media and neointima in the lefl carotid artery increased as a result of Angll infusion from resp. $0.13 \pm 0.01$ and $0.12 \pm 0.02 \mathrm{~mm}^{2}$ in the $\mathrm{NaCl}$ group to $0.16 \pm 0.01$ and $0.20 \pm 0.02 \mathrm{~mm}^{2}$ in the Angll group.

In the right carotid artery, the wet weight per vessel length, including the adventitia, media and endothelium, increased $40 \%$ following Angll infusion (table 9.1). Angll did not change the wet weight per vessel length in the left carotid artery. Also the dry weight per vessel length was increased in the right carotid artery foliowing Angl infusion, but not in the left carotid artery. In the right carotid artery the dry weight to wet weight ratio was lower in the Angll group than 


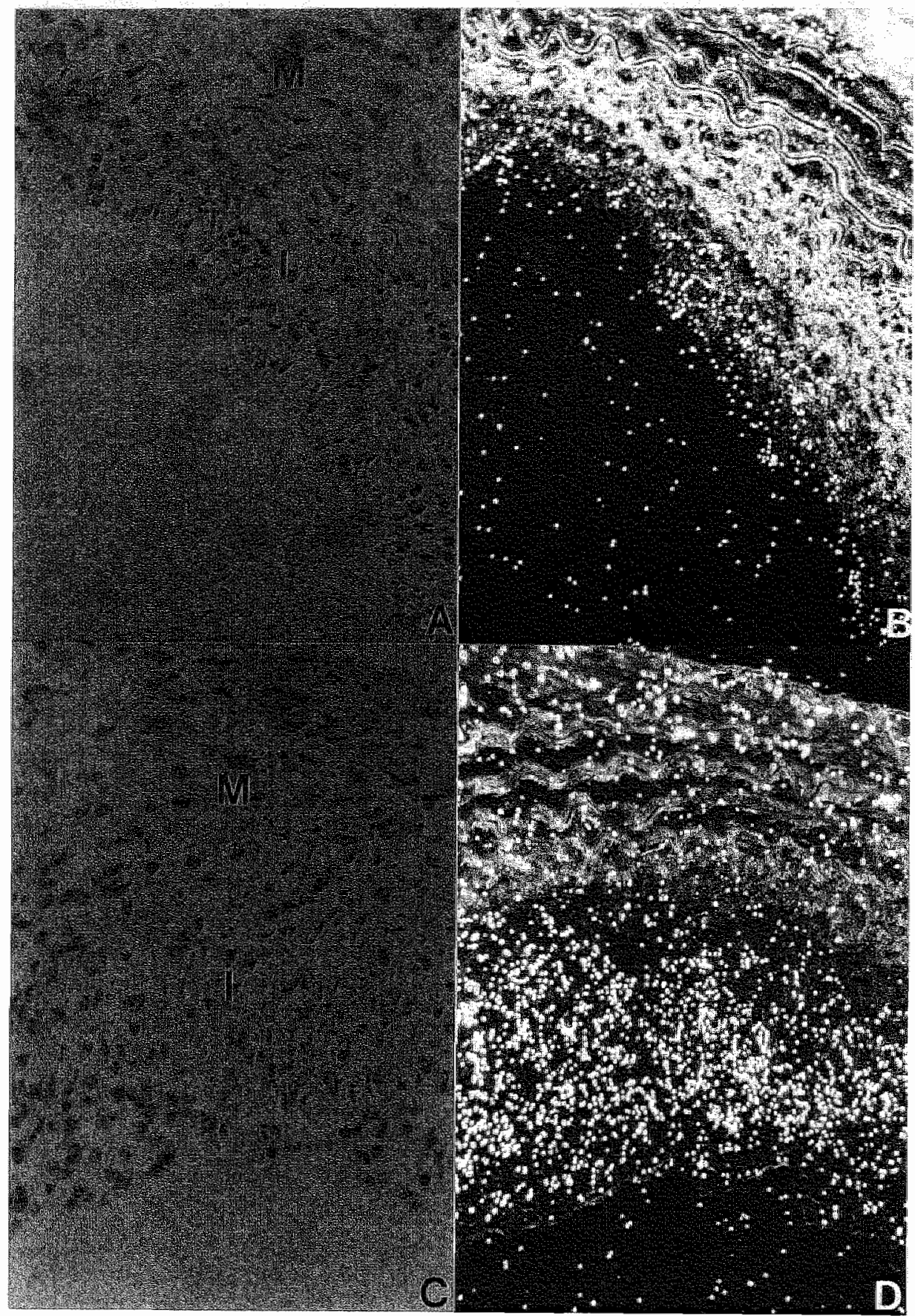

Figure 9.2. Photomicrograph (400x) of a cross-section of a balloon injured left carotid artery hybridized with ${ }^{3} \mathrm{~S}$-labeled elastin probe. Left panels $(A$ and $C)$ represent bright field microscopy, right panels (B and D) represent dark fueld microscopy. (A) and (B) $\mathrm{MaCl}$ group; (C) and (D) Angll group. I= intima, $M=$ media. 


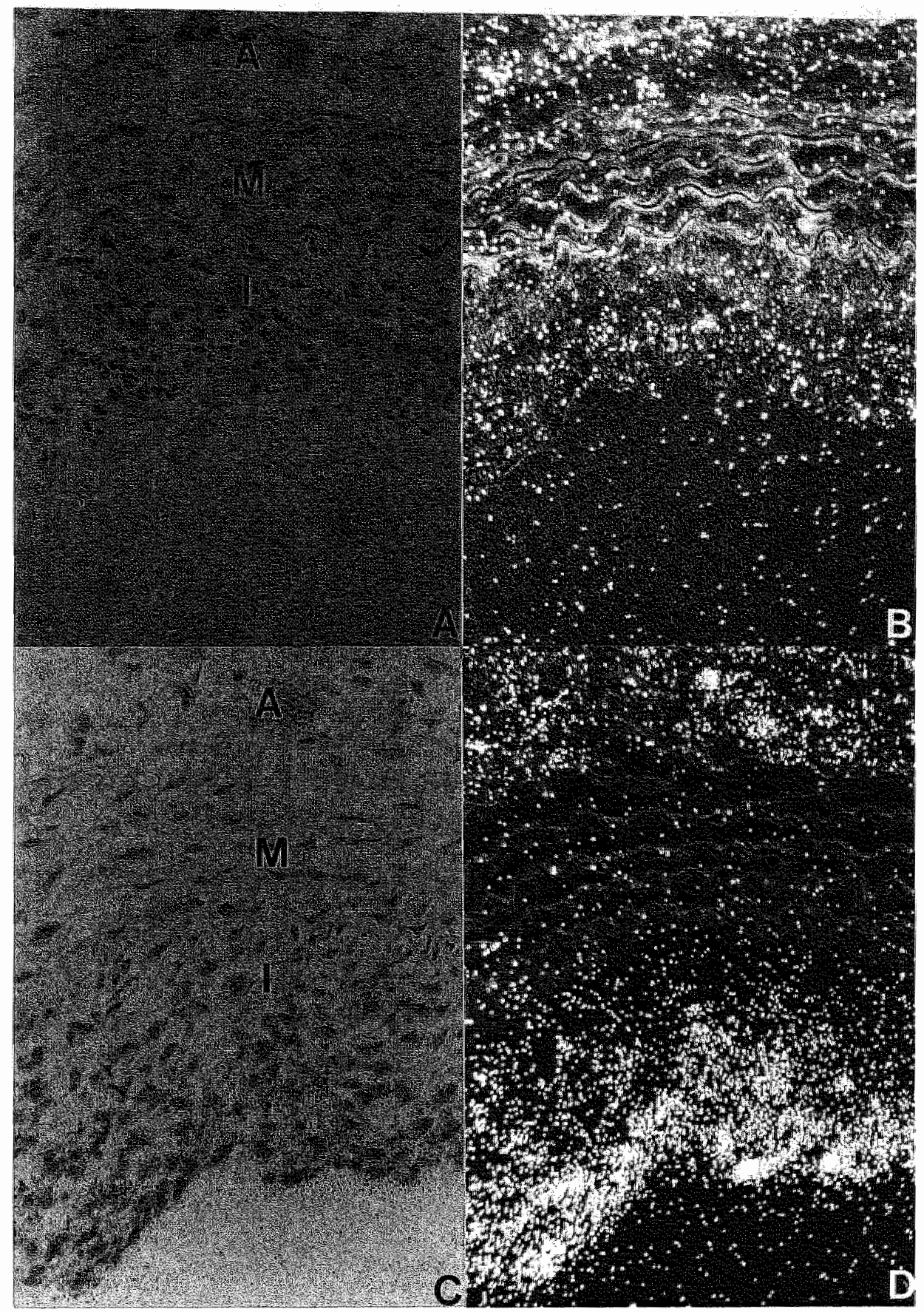

Figure 9.3 Photomicrograph $(400 \mathrm{x})$ of a crossesection of a balloon injured left carotid antery hybridized with $\Gamma^{35} S$-labeled collagen type I probe. Left panels (A and C) represent bright field microscopy, right panels represent dark freld microscopy. (A) and (B): $\mathrm{NaCl}$ group; (C) and (D): Angll group. $I=$ intima, $M=$ media, $A=$ adventitia. 
in the $\mathrm{NaCl}$ group, $0.24 \pm 0.01$ vs. $0.28 \pm 0.02$, whereas in the left carotid artery the dry weight to wet weight ratios were not different in the AngIl and the $\mathrm{NaCl}$ group, resp. $0.24 \pm 0.01$ and $0.23 \pm 0.01$. In both the $\mathrm{NaCl}$ group and the Angll group the dry weights per length were lower in the neointima than in the media (table 9.1).

Table 9.1 Effects of angiotensin II on the cross-sectional area and weight parameters in the media and neointima.

\begin{tabular}{|c|c|c|}
\hline & $\mathrm{NaCl}$ & Angll \\
\hline \multicolumn{3}{|l|}{$\operatorname{CSA}\left(m m^{2}\right)$} \\
\hline re media & $0.11 \pm 0.01$ & $0.16 \pm 0.01^{*}$ \\
\hline Ic media & $0.13 \pm 0.01$ & $0.16 \pm 0.01^{*}$ \\
\hline lo meontima & $0.12 \pm 0.02$ & $0.20 \pm 0.02^{*}$ \\
\hline \multicolumn{3}{|c|}{ Wet weight/vessel length (mg/cm) } \\
\hline re & $3.99 \pm 0.45$ & $5.54 \pm 0.25^{*}$ \\
\hline lc & $7.42 \pm 0.26^{\circ}$ & $8.92 \pm 0.44^{+}$ \\
\hline \multicolumn{3}{|c|}{ Dry weight/vessel length (mg/cm) } \\
\hline re & $1.10 \pm 0.09$ & $1.32 \pm 0.09$ \\
\hline le & $1.80 \pm 0.05^{+}$ & $2.04 \pm 0.07^{*+}$ \\
\hline \multicolumn{3}{|c|}{ Dry-to-wet weight ratio } \\
\hline re & $0.28 \pm 0.02$ & $0.24 \pm 0.01^{\circ}$ \\
\hline te & $0.2410 .01^{*}$ & $0.23 \pm 0.01$ \\
\hline \multicolumn{3}{|c|}{ Dry weight/vessel length $(\mathrm{mg} / \mathrm{cm})$} \\
\hline ro media & $0.41 \pm 0.01$ & 0.6540 .11 \\
\hline Ic media & 0.69 & $0.79 * 0.06$ \\
\hline lo neointina & $0.22 \pm 0.03^{\circ}$ & $0.28 \pm 0.04^{*+}$ \\
\hline
\end{tabular}

Abbreviations: re = right carotid artery; $\mathrm{tc}=$ left carotid antery

Data are represented as mean $\mathrm{SEM}(\mathrm{n}=1-5)$;

*) significantly different from $\mathrm{NaCl}, \mathrm{p}<0.05$

*) signilicanty different from the right carotid media, $p<0.05$

t+) signiticantly different from left carotid media, $p<0.05$. 


\section{Elastin protein in the media and neointima: effects of Angll \\ Morphometry}

The elastin and collagen areas were calculated in both relative and absolute terms (table 9.2 and 9.3). Approximately $35 \%$ of the media and $17 \%$ of the neointima area was occupied by elastin. In the media of the right carotid antery the relative elastin area (the percentage of the total measured tissue area that stained positive for elastin) was $35.5 \pm 1.2 \%$ in the $\mathrm{NaCl}$ group and decreased to $24.4 \pm 1.5 \%$ following Angll infusion. In the media of the injured left carotid artery the relative elastin area did not change, and was $40.3 \pm 5.3 \%$ in the $\mathrm{NaCl}$ group and $35.2 \pm 4.5 \%$ in the AngII group. The relative elastin area in the neointima was always smaller than in the media and decreased from $17.4 \pm 3.9 \%$ in the $\mathrm{NaCl}$ group to $11.6 \pm 1.2 \%$ following AngII infusion.

The relative elastin area multiplied by the respective total cross-sectional area yields the total area of elastin protein in the media or neointima (table 9.2). In the neointima the total area occupied by elastin was lower than in the media. In the media of the right carotid artery no difference between the total elastin area in the $\mathrm{NaCl}$ group and the Angll group were found, $0.032 \pm 0.004 \mathrm{~mm}^{2}$ and $0.030 \pm 0.004$ $\mathrm{mm}^{2}$ respectively. Also, in the media and neointima of the left carotid artery there were no changes in total elastin areas between the $\mathrm{NaCl}$ and the $\mathrm{Angll}$ group, resp. $0.046 \pm 0.005 \mathrm{~mm}^{2}$ and $0.025 \pm 0.008 \mathrm{~mm}^{2}$ in the media and neointima of the $\mathrm{NaCl}$ group, versus $0.050 \pm 0.006 \mathrm{~mm}^{2}$ and $0.030 \pm 0.004 \mathrm{~mm}^{2}$ in the Angll group.

Table 9.2 Effects of Angll on the relative and absolute elastin content in the media and Ineointima.

\begin{tabular}{|c|c|c|}
\hline Morphometry & $\mathrm{NaCl}$ & Angll \\
\hline \multicolumn{3}{|c|}{ Relative elastin area $(\%)$} \\
\hline re media & $35.5 \pm 1.2$ & $24.4 \pm 1.5^{\circ}$ \\
\hline lo media & $40.3 \pm 5.3$ & $35.2 \pm 4.5$ \\
\hline lo neointima & $17.4 \pm 3.9^{i+4}$ & $11.6 \pm 1.2^{i 4}$ \\
\hline \multicolumn{3}{|c|}{ Total elastin positive area $\left(\times 10^{-2} \mathrm{~mm}^{2}\right)$} \\
\hline ro media & $3.2 \pm 0.4$ & $3.0 \pm 0.4$ \\
\hline lo media & $4.6 \pm 0.5$ & $5.0 \pm 0.6$ \\
\hline lc neointima & $2.5 \pm 0.8^{+i t}$ & $3.0 \pm 0.4^{n ! 4}$ \\
\hline
\end{tabular}


The 9.2 (comtinued) Biochemistry

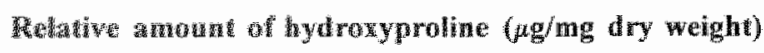

\begin{tabular}{|c|c|c|}
\hline re medua & $12.6 \pm 0.4$ & $7.7 \pm 1.4$ \\
\hline We mediat & 18.0 & $12.1 \pm 0.5$ \\
\hline Ie mointinat & $12.3 \pm 1.2$ & $9.4 \pm 0.1$ \\
\hline \multicolumn{3}{|c|}{ 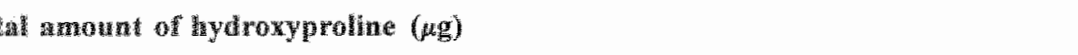 } \\
\hline re thediat & $5.2 \pm 0.3$ & $4.8: 0.6$ \\
\hline lc media & 12.4 & $9.5 \pm 0.6$ \\
\hline ke neontima & $2.7 \pm 0.6$ & $2.6 \pm 0.4^{+4}$ \\
\hline
\end{tabular}

Abbrewathons: rc = right carotid artery; lc = left carotid artery

Duta represent meantSEM, $n=1-5$

* signifcantly different from $\mathrm{NaCl}, p<0.05$

4) significantly different from right carotid media, $\mathrm{p}<0.05$

$+\rightarrow$ significantly different from left carotid media, $p<0.05$

\section{Hydroxyproline measurements}

No differences in the relative amount of elastin (i.e. the hydroxyproline amount in the cyanogen bromide residue per $\mathrm{mg}$ dry weight) were found in the different vessel layers (table 9.2). The total amounts of elastin in each of the vessel layers were not different between the $\mathrm{NaCl}$ group and the Angll group (table 9.2). In the right carotid media the total hydroxyproline amount in the cyanogen bromide residue was $5.2 \pm 0.3 \mu \mathrm{g}$ in the $\mathrm{NaCl}$ group versus $4.8 \pm 0.6 \mu \mathrm{g}$ in the AngIl group. In the left carotid media and neointima the total hydroxyproline amounts were resp. $12.4 \mu \mathrm{g}$ and $2.7 \pm 0.6 \mu \mathrm{gg}$ in the $\mathrm{NaCl}$ group versus resp. $9.5 \pm 0.6 \mu \mathrm{g}$ and $2.6 \pm 0.4 \mu \mathrm{g}$ in the Angll group.

\section{Collagen in the media and neointima: effeets of AngII}

Morphometry

Approximately $15 \%$ of the media area of the right carotid artery was collagen. This relative collagen positive area decreased following Angll infusion from $14.5 \pm 0.9 \%$ in the $\mathrm{NaCl}$ group to $9.4 \pm 1.0 \%$ in the Angll group (table 9.3). Such a decrease in the relative collagen area was not found in the media of the left carotid artery, where this parameter did not change, $15.2 \pm 1.0 \%$ in the $\mathrm{NaCl}$ group vs. $13.5 \pm 2.7 \%$ in the Angll group. In the $\mathrm{NaCl}$ group the relative collagen area in the neointima was lower than in the media but increased following AngII infusion from $2.4 \pm 0.5 \%$ in the $\mathrm{NaCl}$ group to $7.4 \pm 2.3 \%$ in the AngII group. The total collagen positive area was determined by multiplying the relative collagen area and the cross-sectional 
area. The total collagen positive areas in the right carotid media were equal in the $\mathrm{NaCl}$ and Angll groups, $0.013 \pm 0.001 \mathrm{~mm}^{2}$. Also, in the left carotid media there were no differences in the total collagen positive area between the $\mathrm{NaCl}$ and Angll group, resp. $0.018 \pm 0.002 \mathrm{~mm}^{2}$ and $0.019 \pm 0.003 \mathrm{~mm}^{2}$. In the left carotid neointima, the total collagen positive area increased from $0.005 \pm 0.002 \mathrm{~mm}^{2}$ in the $\mathrm{NaCl}$ group to $0.020 \pm 0.005 \mathrm{~mm}^{2}$ in the Angll group.

\section{Hydroxyproline measurements}

The relative collagen amount is the sum of the concentrations of cross-linked and non-cross-linked collagen (table 9.3). In the media of the $\mathrm{NaCl}$ group approximately $15 \%$ of the total collagen was not cross-linked. In the neointima approximately $40 \%$ of the total collagen was not cross-linked. Anglf had no influence on the relative amount of cross-linked collagen.

In the right carotid media, approximately $10 \%$ of the dry weight consisted of collagen and this was not changed following AngII infusion. Also, in the media and neointima of the injured left carotid artery, the relative collagen amount: remained unchanged. The total amounts of collagen in the different vessel layers were not different between the $\mathrm{NaCl}$ group and the Angll group. In the right carotid media the total hydroxyproline amount was $4.4 \pm 1.0 \mu \mathrm{g}$ in the $\mathrm{NaCl}$ group versus $6.1 \pm 1.9 \mu \mathrm{g}$ in the AngII group. The left carotid media and neointima contained resp. 5.7 and $2.4 \pm 0.6 \mu \mathrm{g}$ hydroxyproline in the $\mathrm{NaCl}$ group vs. $6.6 \pm 0.9$ and $1.5 \pm 0.3 \mu \mathrm{g}$ in the Angll group (table 9.3).

Table 9.3 Effects of Angll on the relative and absolute collagen content in the media and neointima.

\begin{tabular}{lll}
\hline Morphometry & $\mathrm{NaCl}$ & Angl \\
\hline Relative collagen content $(\%)$ & & \\
rc media & $14.5 \pm 0.9$ & $9.4 \pm 1.0^{\circ}$ \\
Ic media & $15.2 \pm 1.0$ & $14.2 \pm 2.7$ \\
Ic neointima & $2.4 \pm 0.5^{* *}$ & $7.7 \pm 2.3^{*}$ \\
Total collagen positive area $\left(\mathbf{1 0 ^ { - 2 }} \mathbf{m m}^{2}\right)$ & & \\
rc media & $1.3 \pm 0.1$ & $1.3 \pm 0.1$ \\
Ic media & $1.8 \pm 0.2$ & $1.9 \pm 0.3$ \\
Ic neointima & $0.5 \pm 0.2$ & $2.0 \pm 0.5^{\circ}$ \\
\hline
\end{tabular}


Table 9.3 (continued) Bjochemistry

Relative amouter of hydroxyproline ( $\mu \mathrm{g} / \mathrm{mg}$ dry weight)

Cross-linked collagen

(CNDir extract)

$\begin{array}{lcc}\text { rc media } & 9.2 \pm 2.1 & 5.9 \pm 1.7 \\ \text { lo media } & 7.2 & 7.4 \pm 0.9 \\ \text { lo neointima } & 7.0 \pm 1.3 & 4.1 \pm 1.5\end{array}$

Non eross-linked collagen

(SDS extraci)

$\begin{array}{lcc}\text { re media } & 1.5 \pm 0.3 & 4.6 \pm 3.0 \\ \text { Ic mediat } & 1.0 & 0.9 \pm 0.1 \\ \text { Ic neointima } & 4.7 \pm 3.0 & 1.5 \pm 0.1\end{array}$

Total collagen

$\begin{array}{lcc}\text { re media } & 10.8 \pm 2.7 & 10.4 \pm 3.8 \\ \text { lo media } & 8.2 & 8.3 \pm 0.9 \\ \text { lo neointima } & 11.8 \pm 4.3 & 5.6 \pm 1.7\end{array}$

Total anount of hydroxyproline $(\mu g)$

Cross-linked collagen

(CNBr extract)

$\begin{array}{lcc}\text { ro media } & 3.8 \pm 1.1 & 3.5 \pm 0.6 \\ \text { lo media } & 5.0 & 5.8 \pm 0.9 \\ \text { to neointima } & 1.5 \pm 0.1 & 1.1 \pm 0.8\end{array}$

Non cross-linked collagen

(SOS extract)
re media
$0.6 \pm 0.1$
$2.7 \pm 1.7$
10 mediá
0.7
$0.7 \pm 0.1$
tc noointima
$1.0 \pm 0.5$
$0.4 \pm 0.1$

Total collagen

$\begin{array}{lcc}\text { ro media } & 4.4 \pm 1.0 & 6.1 \pm 1.9 \\ \text { lo media } & 5.7 & 6.6 \pm 0.9 \\ \text { lo neointima } & 2.4 \pm 0.6 & 1.5 \pm 0.3\end{array}$

Abbreviations: $\mathrm{nc}=$ right carotid artery; lo $=$ left carotid artery 
Data represent meantSEM, $n=1-5$

*) significantly different from $\mathrm{NaCl}, \mathrm{p}<0.05$

*) significantly different from right carotid media, $0<0.05$

$++)$ significantly different from left carotid media, $p<0.05$

\section{DISCUSSION}

In the present study the effects of a 2 week infusion of Angll on the mRNA expression and protein amount of two major components of the extracellular matrix, elastin and collagen, were investigated in the balloon injured rat carotid artery. AngII infusion increased the cross-sectional area of all carotid smooth muscle cell layers, but had no effect on the total amount of elastin and collagen protein in the media. In the neointima, Angll had no effect on the total elastin amount and increased the collagen amount, but only in the morphometrical analysis. The in situ hybridization studies suggest increased levels of both elastin and collagen $\alpha_{1}(\mathrm{I})$ and $\alpha_{1}(\mathrm{III})$ mRNA at the end of a 2 week infusion period of Angll.

Synthesis of elastin and collagen, represented by their mRNA expression, was evident in the left carotid artery neointima, and to some extent in the media. This is in agreement with other studies in which increased mRNA levels of elastin, and collagen type I and III were measured in the neointima of the porcine thoracic aorta (3), and in the rat carotid neointima 2 weeks after balloon injury (32). Increased levels of collagen type I and III were also found in the intima of stenotic parts of human aortic coarctations in comparison with non-stenotic areas (35) and in neointimal macrophages in human atherosclerotic pulmonary artery (10). Although we did not perform a quantitative (Northern blot) analysis, the in situ hybridization studies suggested that AngII increased the expression of elastin mRNA and of collagen type I and III mRNA in the neointima, but not in the media. These findings are in agreement with the results of another in vivo study where AngII was infused at a comparable infusion rate as in our studies. There, Angll increased the mRNA expression of fibronectin, but not of collagen type I in the rat aortic media (30). In contrast, Angll increased the expression of collagen type $1 \mathrm{mRNA}$ in cultured SMC of the media of the rat thoracic aorta (25). The difference in effects of Angll on collagen gene expression may be explained by possible differences between SMC in vivo and in vitro.

In the present study infusion of Angll for 2 weeks had no effect on the tolat amount of elastin and collagen protein in the media and only increased the collagen protein amount in the neointima. Administration of the ACE inlibitor enalapril during 5 weeks, decreases the relative elastin and collagen amounts in the carotid 
artery of 4 weeks old, normotensive rats (3I), suggesting stimulatory effects of AngIl on elastin and collagen protein deposition. The discrepancy in the results between the 2 studies may be explained by the age difference of the rats (young versus adult), by the duration of the treatment ( 5 weeks versus 2 weeks) and by possible other effects of ACE inhibition, like the inhibition of the bradykinin degradation (36).

Most of the studies investigating possible changes in the extracellular matrix in the vessel wall have used experimental models of hypertension. In the majority of these studies the total protein amounts of elastin and collagen in the media increased following hypertension, whereas the relative elastin and/or collagen contents were not affected, which indicates that the changes in extracellular matrix proteins are proportional to the increase in vessel wall mass $(17,31,33,34,37$ 39). For instance, clipping of the rat renal artery (two kidney one clip) for a period of 8 weeks, caused a significant rise in blood pressure, thoracic aorta medial crosssectional area and total amounts of collagen and elastin in comparison with sham controls (37). However, the relative collagen and elastin contents, expressed as percentage of vessel dry weight, were not different from the normotensive vessels. Also in the Dahl salt sensitive rat, the total elastin content increased in the thoracic aorta in comparison with the control groups, but the relative elastin content was not altered (33).

In the present study, in which the infusion of AngII also resulted in increased systolic blood pressures (see chapters 4 and 6), a decrease in the relative elastin, but not collagen protein content was found in the media of the carotid artery, whereas Angll had no effect on the total amount of elastin and collagen protein in the media. This indicates a disproportional change in the extracellular matrix following a 2 week infusion of AngII. At present it is not clear what the reason is for the apparent lack in increase of elastin and collagen protein amount during Angll. One possible explanation may be that the increase in extracellular matrix proteins is delayed as compared to the increase in smooth muscle mass (DNA anc/or volume) and that an infusion period of 2 weeks was not long enough to increase collagen and elastin protein. This possibility is supported by the results of another study, where ACE inhibition affected the elastin and collagen content on the thoracic aorta media, but only after 5 weeks of treatment, whereas no effects were observed after 2 weeks of treatment (31).

The lack of effect of a 2 week infusion period on the elastin and collagen amount in the media seems to be in contrast to the earlier described increase in SMC DNA synthesis during Angll (40, chapter 4-6). This might suggest that the regulation of the metabolism of the two extracellular matrix proteins is different from the regulation of DNA synthesis. However, it is important to realize that at this point 
in time the available data are not complete enough for a fair comparison. For instance, we have measured a 2 week cumulative DNA synthesis, but only measured collagen and elastin mRNA synthesis at one time point, i.e. the end of the 2 week infusion of Angll. Thus, it is conceivable that we would have found increased collagen and/or elastin mRNA contents if we had been able to measure a cumulative mRNA content over 2 weeks (or no effect on SMC DNA synthesis, if we had measured this parameter at the end of the 2 week infusion period only). Also, we do not know whether an increased SMC DNA synthesis during Angll results in an increased DNA content.

The mechanism through which AngII may modulate the metabolism of extracellular matrix proteins in vivo is not clear. One possibility is that changes in extracellular matrix are a consequence of the increased blood pressure. Comparable changes in extracullar matrix in Angll dependent and Angll independent models of hypertension $(33,37)$ support this possibility. Other data suggest that the effects of AngII on the extracellular matrix are indirect and involve other growth regulatory molecules. AngIl is known to induce PDGF-A mRNA expression $(41,42)$ and PDGF is a potent stimulator of collagen synthesis (43). Also other growth regulatory systems, such as TGF- $B_{1}(44)$ and bFGF (45), can be induced by Angll in vitro and are known to interact with extracellular matrix proteins, including collagen (46-51).

We clearly need more studies before we can draw firm conclusions on the effects of Angll on the synthesis of elastin and collagen in vivo, but the data presented thus far suggest that the effects of AngII on the vascular smooth muscle may be different from its effects on the extracellular matrix proteins elastin and collagen and that the effects in the neointima may be different from those in the media. The large content of these proteins in the normal media and in the neointima and the possibility that drug effects on SMC and extracellular matrix may differ, indicate 1) that pharmacological interventions in the synthesis of extraceltular matrix proteins may be clinically important and 2) that studies on possible drug effects on the vascular wall should include not only the smooth muscle but also the extracellular matrix. 


\section{REFERENCES}

1. Gerrity, RG; Cliff, WF: The aortic tunica media of the developing rat. I. Quantitative steredogic and biochemical analysis. Lab Invest 1975;32:585-600.

2. Barnes, My: Collagens in Atherosclerosis. Collagen Rel Res 1985;5:65-97.

3. Boyd, CD; Kniep, AC; Pierce, RA; Deak, SB; Karboski, C; Miller, DC; Parker, MI; Mackenzie, JW; Rosenbloom, $J$; Scott, GE: Increased elastin mRNA levels associated with surgically induced intimal injury. Conn Tiss Res 1988;18:65-78.

4. Clowes, $\mathrm{AW}$; Reidy, MA; Clowes, MM: Kinetics of cellular proliferation after anterial injury. 1. Smooth muscle growth in the absence of endothelium. Lab Invest 1983;49:327333.

5. Yla-Hettuala, S; Sumuvuori, H; Karkola, K; Mottonen, M; Nikkari, T: Glycosaminoglycans in normal and atherosclerotic human coronary arteries. Lab Inwest 1986;54:402-407.

6. Shekhonin, BV; Domogatsky, SP; Idelson, GL; Koteliansky, VE; Rukosuev, VS: Relative distribution of fibronectin and type I, II, IV, V collagens in normal and atherosclerotic intima of human arteries. Atherosel 1987;67:9-16.

7. Greil, $R$; Fasching, $B$; Huber, $H$ : In situ hybridization for the detection of low copy numbers of cabl oncogene mRNA in lymphoma cells: technical approach and comparison with results with anti-oncoprotein antibodies. Lab Invest 1989:60:574-582.

8. Forrester, JS; Fishbein, M; Helfant, R; Fagin, J: A paradigm for restenosis based on cell biology: clues for the development of new preventive therapies. I Am Coll Cardiol 1991:17:758-769.

9. Ip, JH; Fuster, V; Badimon, L; Badimon, J; Taubman, MB; Chesebro, JH: Syndromes of accelerated atherosclerosis: role of vascular injury and smooth muscle cell proliferation. I Am Coll Cardiol 1990;15:1667-1687.

10. Liptay, MJ; Parks, WC; Mecham, RP; Roby, J; Kaiser, LR; Cooper, JD; Botney, MD: Neointimal macrophages colocalize with extracellular matrix gene expression in human atherosclerotic pulmonary arteries. I Chin Invest 1993,91:588-594.

11. Snow, AD; Bolender, RP; Wight, TN: Clowes, AW: Heparin modulates the composition of the exiracellutar matrix domain surrounding arterial smooth muscle cells. Am J Pathol $1990 ; 137: 313-330$.

12. Madri, JA: Basson, MD: Extracellutar matrix-cell interactions: dynamic modulators of cell, tisste and organism structure and function. Lab Invest 1992;66:519-52T.

13. Armentano, RL; Levenson, J; Barra, J; Fischer, E; Breibart, J; Pichel, R; Simon, A: Assesment of elastin and collagen contribution to aortic elasticity in conscious dogs. Am $J$ Physiol 1991:260:H1870-H1877. 
14. Mulvany, MJ: A reduced elastic modulus of vascular wall components in hypentension? Hypertension 1992;20:7-9.

15. Iwatsuki, K; Cardinale, Ol; Spector, S. Udenfriend, S: Hypertension: increase in collagen biosynthesis in arteries but not in veins. Science $1977 ; 198: 403-404$.

16. Nissen, R; Cardinale, GJ; Udenfriend, S: lncreased turnover of atterial collagen in hypertensive rats. Proc Natl Acad Sei USA 1978:75:451-453.

17. Anversa, P; Melissarri, M; Tardini, A; Oliveti, G: Connective tissue accumulation in the left coronary artery of young SHR. Hypertension 1984;6:526-529.

18. Poiani, GJ; Tozzi, CA; Yoln, SE; Pierce, RA; Belsky, SA; Berg, RA; Yu, SY; Deak, SB; Riley, DJ: Collagen and elastin metabolism in hypertensive pulmonary arteries of rats. Circ Res $1990 ; 66: 968-978$.

19. Daemen, MJ; Lombardi, DM; Bosman, FT; Schwartz, SM: Angiotensin II induces smooth muscle cell proliferation in the nomal and injured rat arterial wall. Ciro Res 1991:68:450456.

20. Owens, GK; Schwartz, SM: Vascullar smooth muscle cell hypertrophy and hyperploidy in the Goldblatt hypertensive rat. Circ Res 1983;53:491.501.

21. Johnson, RJ; Alpers, CE; Yoshimura, A; Lombardi, D; Pritzl, P; Floege, J; Schwartz, SM: Renal injury from angiotensin 11-mediated hypertension. Hypertension 1992;19:464474.

22. Majack, RA; Coates Cook, S; Bonstein, P: Control of snooth muscle cell growth by components of the extracellular matrix: autocrine rote for thrombospondin. Proc Natl Acad Sci USA $1986 ; 83,9050-9054$.

23. Scott-Burden, T; Hahn, AWA; Resink, TJ; Buhler, FR: Modulation of extracellular matrix by angiotensin Ir: stimulated glycoconjugate synthesis and growth in vascular smooth muscle cells. J Cardiovase Pharmacol 1990:16:536-541.

24. Bell, L; Madri, JA: Influence of the angiotensin system on endothelial and smooth muscle cell migration. Am J Pathol 1990;137:7-12.

25. Kato, H; Suzuki, H; Tajima, S; Ogata, Y; Tominaga, T; Sato, A; Saruta, T; Angiotensin II stimulates collagen symthesis in cultured vascular smooth muscle cells. J Hypentens 1991:9:17.22.

26. Scott-Burden, T; Resink, TJ; Hahn, AW; Buhler. FR: Induction of thrombospondin expression in vascular smooth muscle cells by angiotensin II. J Cardiovasc Pharmacol 1990:16 (Suppl.7):S17-S20.

27. Scott-Burden, T; Resink, TJ; Hahn, AW; Buhler, FR: Angiotensin-induced growth related metabolism is activated in cultured smooth muscle cells from spontaneously hypertensive rats and Wistar-Kyoto rats. Am IHypertens 1991;4;183-188. 
28. Mackie, EJ; Scott-Burden, T; Hahn, AW; Kern, F; Bernhardt, J; Regenass, S; Weller, A; Buhler, FR: Expression of tenascin by vascular smooth muscle cells. Alterations in thypertensive rats and stimulation by angiotensin 11 . Am J Pathol 1992;141:377-388.

29. Sharif, BG; LaFleur, DW; Pirola, CJ; Forrester, JS; Fagin, JA: Angiotensin II regulates terascin gene expression in vascular smooth muscle cells. J Biol Chem 1992;267:2391023915.

30. Takasaki, I: Chobanian, AV; Sarzani, $R$; Brecher, P: Effect of hypertension on fibronectin expression in the rat aorta. J Biol Chem 1990;265:21935-21939.

31. Keeley, FW; Elmoselhi, A; Leenen, FH: Enalapril suppresses mormal accumulation of elastin and collagen in cardiovascular tissues of growing rats. Am J Physiol 1992:262:H1013-111021.

32. Majesky, MW; Giachelli, CM; Reidy, MA; Schwartz, SM: Rat carotid neointimal sunooth muscle cells reexpress a developmentally regulated mRNA phenotype during repair of arteriat injury. Circ Res 1992;71:759-768.

33. Keeley, FW; Alatawi, A: Response of aortic elastin syrthesis and accumulation to developing hypertension and the inhibitory effect of colchicine on this response. Lab Invest $1991 ; 64: 499-507$.

34. Todorovich-Hunter, L; Johnson, DJ; Ranger, P; Keeley, FW; Rabinovitch, M: Altered elastin and collagen synthesis associated with progressive pulmonary hypertension induced by monocrotaline. Lab Invest $1988 ; 58: 184-195$.

35. Jaeger, E; Rust, S; Seharffetter, K; Roessner, A; Winter, J; Buchholz, B; Althaus, M; Rauterberg, J: Localization of cytoplasmic collagen mRNA in human aortic coarctation: mRNA enhancement in high blood pressure-induced intimal and medial thickening. J Histochem Cytochem 1990;38:1365-1375.

36. Erdos, EG: Angiotensin I converting enzyme and the changes in our concepts through the years. Lewis K. Dahl memorial lecture. Hypertension 1990;16:363-370.

37. Wolinsky, H: Response of the rat aortic media to hypertension. Circ Res 1970;26:507-522.

38. Foidart, I; Rorive, $\mathrm{G}$; Nusgens, B; Carlier, P; Lapiere, $\mathrm{C}$. Early biochemical changes in the arterial wall of renal hypertensiwe rats. Biochem approach Hypertension 1979:241-248.

39. Isoyama, $\$$; Ito, N: Satoh, K; Takashima, T: Collagen deposition and the reversal of comary reserve in cardinc hypertrophy. Hypertension 1992;20:491-500.

40. van-Kleef, EM: Smits, JF; De-Mey, JG; Cleutjens, IP; Lombardi, DM; Sclwartz, SM; Daemen, MI: Alpha 1-adrenoreceptor blockade reduces the angiotensin II-induced vascular smooth muscle cell DNA symthesis in the rat thoracic aorta and carotid artery. Circ Res $1992 ; 70: 1122-1127$. 
41. Naftilan, AJ; Pratt, RE; Dzau, VJ: Induction of platelet-derived growth factor Awchain and c-myc gene expressions by angiotensin II in cultured rat vascular smooth muscle cells. I Clin Invest $1989: 83: 1419-1424$.

42. Cercek, B; Fishbein, MC; Forrester, IS; Helfant, RH; Fagin, JA: Induction of insulin-like growth factor $I$ messenger RNA in rat aorta after balloon denudlation. Circ Res $1990 ; 66: 1755-1760$.

43. Burke, $\mathrm{MM}$; Balian, $\mathrm{G}$; Ross, $\mathbb{R} ;$ Bomstein, $\mathrm{P}$; Symhesis of types I and U1 procollagen and collagen by monkey aortic smooth muscle cells in witro. Biochem 1977:16:3243-3249.

44. Gibbons, GH; Pratt, RE; Dzau, VJ: Vascular smooth muscle cell hypertrophy ws. hyparplasia. Autocrime transforming growth factor- $\beta 1$ expression deternimes growth response to angiotensin II. J Clin Invest 1992;90:456-461.

45. Itoh, H; Mukoyana, M; Pratt, RE; Gibbons, GH; Dzau, VJ: Multiple autocrine growh factors modulate vascular smooth muscle cell growth response to angiotensin. II. I Clin Invest 1993;91:2268-2274.

46. Majors, A; Elrhart, LA: Basic fibroblast growth factor in the extracellular matrix suppresses collagen synthesis and type IIl procollagen mRNA levels in arterial smooth muscle cell cultures. Arterioscler Thromb 1993;13:680-686.

47. Ignotz, RA; Endo, T; Massague, J: Regulation of fibronectin and type I collagen mRNA levels by transforming growth factor- $\beta$. I Biol Chem 1987;262:6443-6446.

48. Roberts, AB; Sporn, MB; Associan, RK; Smith, JM; Roche, NS; Wakefield, LM; Heine, UI; Liotta, LA; Falanga, V; Kelrl, JH; Fauci, AS: Transforming growth factor type-beta: rapid induction of fibrosis and angiogenesis in vivo and stimulation of collagen formation in vitro. Proc Natl Acad Sci USA 1986;83:4167-4171.

49. Tan, EML; Ronda, S; Greenbaum, SG; Moore, JH; Fox, JW; Sollberg, S: Acidic and basic fibroblast growth factor down-regulated collagen gene expression in keloid fibroblasts. Am J Pathol 1993;142:463-470.

50. Amento, E; Ehsani, N; Palmer, H; Libby, P: Cylokines and growth factors positively and negatively regulate interstitial collagen gene expression in hymant vascular smooth muscle cells. Arterioscler Thromb 1991:11:1223-1230.

51. Clark, R; Folkword, J; Hart, C; Murray, M; McPherson, J: Platelet isoforms of platelet drived growth factor stimulate fibroblasts to contract collagen matrices. I Clin Invest $1989 ; 84: 1036-1040$. 

DISCUSSION 


\subsection{GENERAL DISCUSSION}

In this thesis, the role of the $\alpha_{4}$-adrenoreceptor in the induction of vascular SMC DNA synthesis by Angll was investigated. The data show that Angll stimulates SMC DNA synthesis and that the effects are heterogeneous. This heterogeneity appeared from differences in the extent of the AngII induced SMC DNA synthesis and from differences in the involvement of the $\alpha_{1}$-adrenoreceptor in this response. Heterogenous effects were found in: 1) the media and the neointima of the injured rat carotid artery. AngIl induced SMC DNA synthesis was higher in the neointima than in the media. The $\alpha_{1}$-adrenoreceptor seems to be involved in the AngIl induced SMC DNA synthesis in the media of the non-injured carotid artery, but not in the media and the neointima of the injured carotid artery. 2) Different elastic arteries of the rat. AnglI infusion caused a heterogeous increase in SMC DNA synthesis in the different arteries investigated and the effects of $\alpha_{1}$-adrenoreceptor blockade were also heterogeneous 3) Young 6 weeks old rats versus adult rats. Whereas AngIl induced SMC DNA synthesis in the adult rats, it did not induce SMC DNA synthesis in different elastic arteries of young rats. $\alpha_{1}$-Adrenoreceptor stimulation by phenylephrine infusion was found to induce SMC DNA synthesis in the thoracic aortic media of young 6 weeks old rats, and in the media of the non-injured right carotid artery, but not in the neointima formed after balloon injury, and finally 4) effects of AngII on SMC DNA synthesis and on extracellular matrix. Whereas infusion of AngII increased SMC DNA synthesis, and the synthesis of elastin and collagen, only minimal effects of AngIl on the amount of extracellular matrix proteins, elastin and collagen, were found.

\subsection{RESTIMULATION OF MEDIA AND NEOINTIMAL SMC. A MODEL FOR STUDVING THE PATHOGENESIS OF RESTENOSIS.}

The balloon injury model is a widespread model to study the mechanism of SMC migration and proliferation. The kinetics of the model have been described and several molecules controlling different steps in the development of a neointima have been elucidlated. Also a number of pharmacological interventions have proven to be succesful in the model and have been applied to human studies on restenosis. In humans, however, most of these interventions have been unsuccesfiul. One of the possible explanations for the difference in effects of interventions on human and animal studies is the fact that drug interventions in animal studies usually start immediately after injury of a previously normal artery. Possible drug effects on neointima development may therefore be due to effects on medial SMC proliferation, medial SMC migration, and on neointimal SMC proliferation. Restenosis in 
humans occurs in an already existing intima and possible drug effects are more restricted to effects on the neointimal cells. These considerations underscore the necessity for better animal models that enable to dissociate possible drug effects on medial and neointimal SMC. The restimulation model as described in this thesis, is an example of a system that enables to dissociate the effects of interventions on medial and neointimal SMC. By using this model we found that medial and neointimal SMC behave differently and that the control of medial SMC growth is quite different from that of neointimal SMC growth.

\subsection{ANGIOTENSIN II AND THE $\alpha_{1}$-ADRENORECEPTOR}

\section{AngII induced SMC DNA synthesis and its mechanism of action}

According to our hypothesis formulated in chapter 1, AngIl and the $\alpha_{1}$-adrenoteceptor cooperate in a parallel fashion and not in a serial fashion (figure 8. 1 ). In the parallel stimulation, both AngII and the $\alpha_{1}$-adrenoreceptor can stimulate SMC DNA synthesis independently, whereas a seria] mechanism implies that stimulation of the $\alpha_{1}$-adrenoreceptor through AngII is necessary to stimulate SMC DNA synthesis. In chapters 7 and 8 the effects of stimulation of the $\alpha_{1}$-adrenoreceptor on SMC DNA synthesis were studied by infusion of phenylephrine. Phenylephrine increased SMC DNA synthesis in thoracic aorta of young, 6 weeks old rats, and in the non-injured right carotid artery of adult rats, indicating the possibility of a serial mechanism, but not excluding the existence of a parallel stimulation.

To further dissociate between centrally mediated effects of Angll on sympathetic activity and effects through an increased release of circulating catecholamines, denervation studies are neccessary. These include local and systemic treatment with 6-hydroxydopamine to cause destruction of adrenergic nerve endings and longlasting depletion of norepinephrine release from the sympathetic nervous system (1) and removal of the adrenal medulla to prevent the possible release of catecholatmines by the adrenals following Angll. To further investigate the $\alpha_{1}$-adrenoreceptor subtype involved in the regulation of SMC DNA synthesis and to identify the subtype in the medial and the neointimal SMC, intervention studies with $\alpha_{1}$-adrenoreceptor subtype specific antagonists as well as gene expression studies are necessary.

\section{AngII induced SMC DNA synthesis and heterogeneity}

The diverse effects of AngII, $\alpha_{1}$-adrenoreceptor blockade and $\alpha_{1}$-adrenoreceptor stimulation on medial and neointimal SMC (chapters 4-6 and 8) are all examples of diversity in the growth responses of medial and neointimal SMC. Also different 
effects of Angll were found in young versus adult rat arteries (chapter 7 ) and between different arteries in the adult rat (chapter 5). One possible explanation for the diversity of SMC growth is a difference in SMC phenotype (2). A relation between the phenotype of the SMC and SMC proliferation was first described by Campbell et al, when they observed, that SMC when put into culture, loose their contractile apparatus before they start to replicate and they called the transition from the contractile to the synthetic state "phenotypic modulation" (3). In recent years, it has been shown that SMC in an atherosclerotic lesion, fetal SMC and neointimal SMC after balloon injury show loss of contractile apparatus (4-8). This concept may also include heterogeneity of the receptor subtype involved, e.g. subtypes of the AT receptor and the $\alpha_{1}$-adrenoreceptor. The concept, however, remains poorly defined at the molecular level and thus does not predict a cause and effect relation between phenotype and growth (9). An alternative explanation for diversity in SMC growth is the existence of several subpopulations of SMC with unique growth properties. Neointimal, but not medial SMC express fetal genes (10, 11), show different gene expression patterns of PDGF-B, cytochrome P450IA1, and elastin (12-14), and increased sensitivity to Angll (15) in comparison with non-injured medial SMC. Furthermore, they have a distinct morphology, and show PDGF independent growth, when put into culture (13). At this point it is not clear whether the diversity in growth responses between medial and neointimal SMC in our studies are due to phenotypic modulation or to the existance of subtypes of SMC.

\section{Effects of Anghl on the extracellular matrix}

AngIl increased the cross-sectional area of the media but had no immediate effect on its collagen and elastin amount (chapter 9), which suggests that the increase in cross-sectional area is primarily due to an increase in the smooth muscle compartment. The relatively low cumulative medial SMC labeling fraction of approximately $5 \%$ ( 16 , chapters 4 and 6 ) suggests that a major contributing factor to the increase in cross-sectional area is an increase in the volume of the individual SMC, rather than an increase in SMC number. Angll also increased the cross-sectional area in the the neointima. In the neointima, we observed an increase in collagen amount, as well as a high SMC labeling fraction (16, chapter 6) suggesting that the increase in cross-sectional area might be due to an increase in extracellular matrix and changes in the smooth muscle cell compartment. 


\subsection{OTHER POSSIBLE MECHANISMS INVOLVED IN THE ANGII INDUCED SMC DNA SYNTHESIS}

\section{Blood pressure}

In our experiments, both prazosin and doxazosin, when infused together with AngIl, did not lower systolic blood pressures. Growth stimulatory effects of Angll are partially attributed to the blood pressure increase that is caused by its vasoactive properties (17-19). To investigate the possible role of increased blood pressure in our studies, we investigated the relation between mean systolic blood pressure and mean cross-sectional area per treatment group in the different studies. As shown in figure $10 \mathrm{~A}$ there is no correlation between blood pressure and the crosssectional area of the media of both non-injured right (regression coefficient $(\mathrm{rc})=$ 0.43 ) and injured left carotid artery $(\mathrm{rc}=0.23)$. Also, the neointimal cross-sectional area (figure $10 \mathrm{~B}$ ) was not influenced by blood pressure changes $(\mathrm{rc}=0.17$ ).
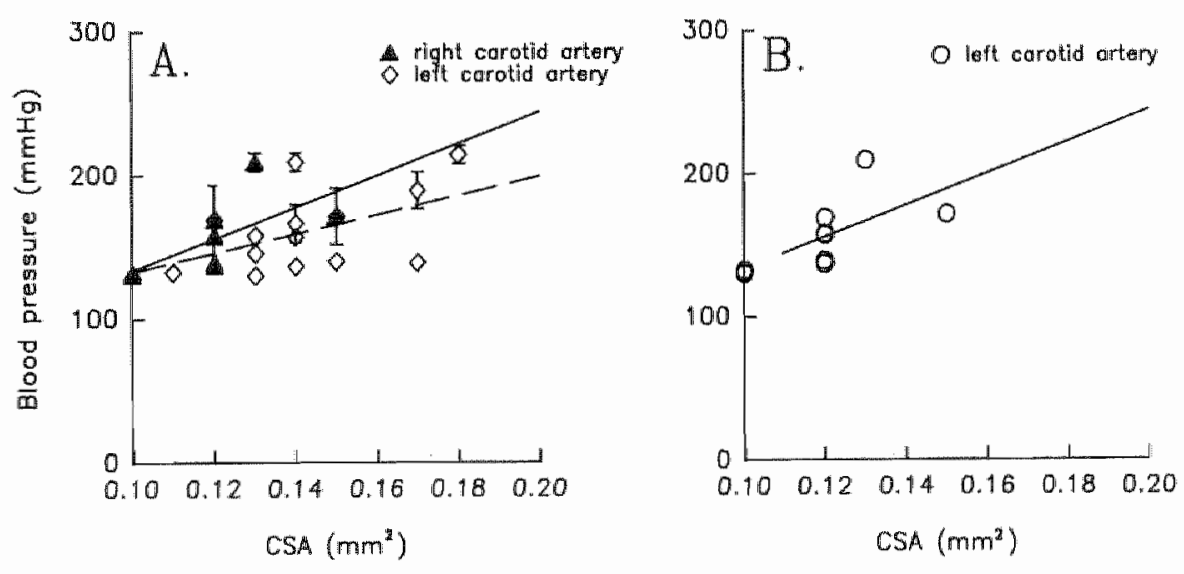

Figure 10.1 Relation between systolic blood pressure and (A) the medial cross-sectional areat of the right and left carotid artery; (B) the neointimal cross-sectional area of the injured left carotid artery.

\section{AT receptor}

Although at least in the media the $\alpha_{1}$-adrenoreceptor is involved in the induction of SMC DNA synthesis, stimulation of SMC DNA synthesis by Angll also implies a role for the AT receptor. In vitro and in vivo data show the involvement of the $\mathrm{AT}_{1}$ receptor in SMC DNA synthesis and extracellular matrix production (20-23). 
and it is reasonable to assume that this receptor plays a role in the growth effects in our studies, although the involvement of the $\mathrm{AT}_{2}$ receptor (24) and the involvement of possible other AT receptors can not be excluded.

\section{Other growth regulatory systems}

In vitro studies have identified other growth factors, such as PDGF-A and TGF- $B_{1}$, that are induced by AngII administration and play a role in SMC proliferation (25, 26) as well as matrix formation (27-30). The functional role of these factors in vivo has as yet not been established. Several in vivo studies do suggest however that these factors may be involved in growth regulation, such as studies by Majesky et al., who demonstrated that medial SMC express PDGF-A mRNA within 6 hours after balloon injury, or after $\alpha_{1}$-adrenoreceptor stimulation $(31,32)$. Periluminal neointimal $S M C$, the region where neointimal proliferation takes place (33), express large amounts of $\mathrm{PDGF}-\mathrm{A}$ and $\mathrm{PDGF}-\mathrm{B}$ receptor mRNA (32). In preliminary experiments we also found increased amounts of PDGF-A mRNA expression by in situ hybridization (unpublished observations) in the luminal neointimal SMC, at four weeks after balloon injury, but higher expression levels of PDGF-A could not be demonstrated by infusion of Angll.

The in vivo presence of TGF- $B_{1}$ mRNA has been demonstrated in both rat neointima (34), as well as in human restenotic lesions (35). Infusion of recombinant TGF$B_{1}$ protein in rats at two weeks after balloon injury of the left common carotid artery was shown to stimulate SMC DNA synthesis in neointimal, but not medial SMC, and was found to be particularly high in SMC lining the luminal surface (34). The role of these and other growth regulatory systems should be investigated by studying the amount of mRNA and protein expression and localization, and by intervention studies, involving both interventions with anti-sense oligonucleotides, antibodies, and if available, receptor antagonists.

\subsection{CRITICAL NOTES}

\section{Angll concentration}

In all but one study, we used a dose of AngI $(0.5 \mathrm{mg} / \mathrm{kg} / \mathrm{day})$. This dose increased the Angll plasma levels (as determined by radioimmunoassay) to $200 \mathrm{pmol} / \mathrm{l}$ as compared to a value of $70 \mathrm{pmol} / \mathrm{l}$ in rats infused with $0.9 \% \mathrm{NaCl}$. Future studies should include studies with lower Angll infusion rates. Another possibility is to study medial and neointimal SMC DNA synthesis and the role of the $\alpha_{1}$-adrenoreceptor in an Angll dependent model of hypertension, like the two kidney one clip hypertension model, a more physiologic AngII dependent model of hypertension. 


\section{BrdUrd concentration}

In the present thesis we used different concentrations of BrdUrd, ranging from 0.8 $\mathrm{mg} / \mathrm{kg} / \mathrm{day}$ to $30 \mathrm{mg} / \mathrm{kg} / \mathrm{day}$. As the results in chapter 3 indicate, no differences in BrdUrd labeling fractions were determined between the high and low dose BrdUrd groups. Also the highest dose of $30 \mathrm{mg} / \mathrm{kg} /$ day used in this thesis was not found to be toxic and the BrdUrd labeling fractions were found to be comparable with $\left[{ }^{3} \mathrm{H}\right] \mathrm{TdR}$ labeling fractions. This is also apparent by comparison of BrdUrd labeling fractions in the balloon injured carotid artery in chapter 6 , with those of the study by Daemen et al.(15), who used [ $\left.{ }^{3} H\right]$ TddR.

\section{Dimethylsulfoxide}

Dimethylsulfoxide (DMSO) had to be used as the solvent for both prazosin and doxazosin. As shown in chapters 4 and 5, DMSO increased the labeling fraction in the thoracic aorta and the carotid artery as compared to the $\mathrm{NaCl}$ group. The stimulatory effects of DMSO on SMC DNA synthesis are puzzling and can not be easily explained. Only a few in vitro studies exist on the effects of DMSO on vascular SMC replication, and these effects vary between no effect at all (36), to a dosedependent decrease in SMC DNA synthesis $(37,38)$. Also, DMSO exerted unexplained and diverse effects on cross-sectional area.

\subsection{POSSIBLE CLINICAL IMPLICATIONS}

The complex regulation of SMC and exiracellular matrix growth is apparent from the results of the studies presented here. Also, in view of the complex biology of restenosis, the discovery of a "magic bullet" (39) is unlikely, and the solution will more likely involve a multifactorial approach $(40,41)$.

Whereas a reduction of neointima formation by the $\alpha_{1}$-adrenoreceptor antagonists prazosin and doxazosin have been demonstrated in the balloon injury model of the rat and the rabbit, these studies did not dissociate between medial and neointimal SMC proliferation, since the drugs were administered directly following balloon injury (42-45). In this thesis, no role for $\alpha_{1}$-adrenoreceptor is demonstrated in neointimal SMC DNA synthesis, suggesting that in the clinical situation no effect is to be expected from $\alpha_{1}$-adrenoreceptor antagonist administration to prevent restenosis.

The findings in this thesis show that neointimal SMC and medial SMC behave differently and react differently to Angll, and $\alpha_{1}$-adrenoreceptor agonists and antagonists. This underscores the importance of studying the effects of drugs in an experimental model with an already formed neointima. 


\section{REFERENCES}

1. Lee, RMKW; Gzik, Dr: Sympatholytic interventions and vascular remodelling. Basic Res Cardiol 1991;86(Suppl.1):55-64.

2. Daemen, MIAP; De Mey, JGR: Heterogeneity of radial structural changes in arteries. Submitted.

3. Chambleycampbell, JH; Campbell, GR; Ross, R: The smooth muscle cell in culture. Physiol Rev 1979;59:1-61.

4. Glukhova, MA; Frid, MG; Koteliansky, VE: Developmental changes in expression of contractile and cytoskeletal proteins in human muscle. J Biol Chem 1990;265:1304213046 .

5. Babaev, VR; Bobryshev, YV; Stenina, OV; Tararak, EM; Gabbiani, G: Heterogemeity of smooth muscle cells in atteromatous plaque of human aorta. Am J Pathol 1990;136:10311042 .

6. Gabbian", $G$; Rungger-Brandle, $E$; Chastonay, $C$ de; Franke, WW: Vimentin-containing smooth muscle cells in aoric intimal thickening after endothelial injury. Lab Invest $1982: 47,265-269$

7. Kocher, O; Skalli, O; Bloom, WS; Gabbiani, G: Cytoskeleton of rat aortic smooth muscle cells. Normal conditions and experimentall intimal thickening. Lab Invest 1984;50:645652.

8. Kocher, O; Gabbian, F; Gabbiani, G; Reidy, MA; Cokay, MS; Peters, H; Huttner, I: Phenotypic features of smooth muscle cells during the evoiution of experimental carotid artery intimal thickening. Biochemical and morphologic studies. Lab Invest 1991;65:459470.

9. Blank, $\mathbb{R S}$; Thompson, MM: Owens, GK: Cell cycle versus density dependence of smooth musclo atpha actin expression in cultured rat aortic smooth muscle cells. J Cell Biol 1988;107:299-306.

10. Majesky, MW; Giachelli, CM; Reidy, MA; Schwartx, SM: Rat carotid neointimal smooth muscle cells reexpress a developmentally regulated mRNA phenotype during repair of arterial injury. Circ Res 1992,71:759.\%68.

11. Han, DK; Liau, G: Identification and characterization of developmentally regulated genes in vascular smooth muscle cells. Circ Res 1992;71:711:-719.

12. Majesky, MW; Benditt, EP; Schwartz, SM: Expressioru and developmental control of platelet-derived growd factor A-chain and B-chain/Sis genes in rat aortic smooth musele cells. Proc Natl Acad Sci USA 1988;85:1524-1528. 
13. Walker, LN; Bowen-Pope, DF: Ross, R; Reidy; MA: Production of platelet-derived growth factor-like molecules by cultured arterial smooth musele cells accompanies proliferation after arterial imjury. Proc Natl Acad Sei USA 1986:83:7311-7315.

14. Giachelli, C; Bae, N; Lombardi, D; Majesky, M; Schwartz, S: Molecular cloning and characterization of $2 \mathrm{~B} 7$, a rat $\mathrm{mRNA}$ which distinguishes smooth muscle cell phenotypes in vitro and is identical to osteopontin (secreted phosphoprotein $1,2 a R$ ). Biochem Biophys Res Commun 1991:177:867-873.

15. Daenen, MJ; Lombardi, DM; Bosman, FT; Schwartz, SM: Angiotensin Il induces smooth muscle cell proliferation in the nomal and injured rat arterial wall. Cire Res $1991: 68: 450.456$.

16. van-Kleef, EM; Smits, JF; De-Mey, JO; Cleutjens, JP; Lombardi, DM; Schwartz, SM; Daemen, MJ: Alpha l-adrenoreceptor blockade reduces the angiotensin II-induced vascular smootln muscle cell DNA synthesis in the rat thoracic aorta and carotid artery. Circ Res 1992;70:1122-1127.

17. Brown, AJ; Casals-Stenzel, J; Gofford, S; Lever, AF; Morton, JJ: Comparison of fast and slow pressor effects of angiotensin 11 in the conscious at. An I Plhysiol 1981;241:14381. H388.

18. Brown, Jj; Casals-Stenzel, J; Cumming, AMM; Davies, DL; Fraser, F; Lever, AF; Morton, JJ; Semple, PF; Tree, M; Roberison, JIS: Angiotensin II, Aldosterone and Arterial Pressure: A Quantitive Approach. Hypertension 1979;1:159-178.

19. Schiffers, PM; Struyker-Boudier. HA; De-Mey, JG: Effects of angiotensin II and angiotensin converting enzyme inhibitors on contractile and growth responses in isolated carotid arteries of the rat. Basic Res Cardiol 1991;86(Suppl.1):83-89.

20. Kauffman, RF; Bean, IS; Zimmerman, KM: Brown, RF; Steinberg, MI: Losartan, a nonpeptide angiotensin II (ANG II) receptor antagonist, inhibits neointima formation following balloon injury to rat carolid arteries. Life Sci 1991:49:223-228.

21. Prescott, MG; Webb, RL; Reidy, MA: Angiotensin-converting enzyme inhibitor versus angtotensin II, ATI receptor antagonist. Effects on smooth muscle coll migration and proliferation after balloon catheter injury. Am \& Pathol 199 1;139:1291-1296.

22. Laporte, 5 ; Escher, E: Neointima formation after vascular injury is angiotensin 11 mediated. Biochem Biophys Res Commun 1992;187:1510 1516.

23. Viswanathan, M; Stromber, C; Seltzer, A; Sagwedra, JM; Balloon angioplasty enhances the expression of angiotensin II ATH receptors in neointima of rat aorta. I Clin invest $1992 ; 90: 1707-1712$

24. Janiak, P; Pillon, A; Prost, J-F; Vilaine, J-P: Role of angiolensin subtype 2 recephor in neointina formation after vascular injury. Hypertension 1992;20:737-745 
25. Gibbons, GH; Pratt, RE; Dzan, W: Vascular smooth muscle cell hypertrophy vs. hyperplasia. Autocrine transforming growth factor- $\beta$ l expressin determines growth response to angiotensin II. J Clin Invest $1992 ; 90: 456-461$.

26. Battegay, EJ; Raines, EW; Seifert, RA; Bowen-Pope, DF; Ross, R: TGF-beta induces binodal proliferation of conneet tve tissue cells via complex control of an autocrine PDGF locp. Cell $1990,63: 515.524$.

27. Majack, RA; Majesky, MW: Goodman, LV: Role of PDGF-A expression in the control of vascular smooth muscle cell growth by transforming growth factorbeta. I Cell Biol $1990: 111: 239-247$.

28. Majors, $\mathrm{A}$; Ehrhart, LA: Basic fibroblast growth factor in the extracellular matrix suppresses collagen synthesis and type III procollagen mRNA levels in arterial smooth muscle cell cultures. Arterioscler Thromb 1993:13:680-686.

29. Ignotz, RA; Endo, T; Massague, J: Regulation of fibronectin and type I collagen mRNA levels by transforming growth factor- $\beta$. J Biol Chem 1987;262:6443-6446.

30. Roberts, AB; Sporn, MB, Associan, RK; Smith, JM; Roche, NS; Wakefield, LM; Heine, Ui: Liotta, LA; Falanga, V; Kehrl, JH; Fauci, AS: Transforming growth factor type-beta: rapid induction of fibrosis and angiogenesis in vivo and stimulation of collagen formation. in vitro. Proc Natl Acad Sci USA 1986;83:4167-4171.

31. Majesky, MW; Daemen, MJ; Schwart, SM: Alpha 1-adrenergic stimulation of platelet. derived growth factor A-chain gene expression in rat aorta. J Biol Chem 1990;265:1082. 1088.

32. Majesky, MW; Reidy, MA; Bowen-Pope, DF; Hart, CE; Wilcox, JN; Schwart, SM: PDGF Ligand and receptor expression during repair of arterial injury. \& Cell Biol $1990 ; 111: 2149-2158$

33. Clowes, AW: Clowes, MM; Reidy, MA: Kinetics of cellular proliferation after arterial injury. III. Endothelial and smooth muscle growth in chronically denuded vessels. Lab Invest 1986;5:295-303.

34. Majesky, MW; Lindner, V; Twardzik, DR; Schwartz, SM; Reidy, MA: Production of transforming growh factor beta I during repair of arterial injury. I Clin Invest $1991: 88: 904-910$

35. Nikd, S; Isner, JM, Pickering, JO; Keaney, M; Leclerc, G; Weir, L: Expression of transforming growth factor $\beta 1$ is increased in human vascular restenosis lestons. J Clin Invest. $1992 ; 90: 1582-1592$.

36. Zhao, J; Zhang, CY: Xu, DM: Hysang, GQ; Xu, YL; Wang, ZY: The antiantherogenic effects of components isolated from pollen typhae. Thromb Res 1990;57:957-966. 
37. Layman, DL: Growth inhibitory effects of dimethyl sulfoxide and dimethysuffone on vascular smooth muscle and endothelial celis in vitro. In Vitro Cell Dev Biol $1987: 23: 422-428$.

38. Katsuda, $S$; Okada, Y; Nakanishi, I; Tanaka, Ji Inhibitory effect of dimethyl sulfoxide on the proliferation of cultured smooth muscle cells: relationship to the cytoplasmic microtubules. Exp Mol Pathol 1988:48:48*58.

39. Hermans, WR: Rensing, BJ; Strauss, BH; Serruys, PW: Prevention of restenosis after percutaneous transluminal coronary angioplasty: the search for a "magic bullet". Aun Heart J 1991;122:171-187.

40. Ferrell, M; Fuster, V; Gold, HK; Chesebro, JH: A dilemma for the 1990s. Choosing appropriate experimental animal model for the prevention of restenosis. Circ $1992 ; 85: 1630-1631$.

41. Dzau, VJ; Gibbons, GH; Cooke, JP; Omoigui, N: Vascular biology and medicine in the 1990s: scope, concepts, potentials, and perspectives. Circ 1993;87:705-719.

42. Fingerle, I; Sanders, KH; Fotev, Z: Alpha-1 receptor antagonists urapidil and prazosin inhibit neointima formation in rat carotid artery induced by balloon catheter injury. Basic Res Cardiol 11991;86(Suppl.1):75-81.

43. OMalley, MK; MeDermott, EW; Mehigan, D; O'Higgins, N.I: Role for prazosin in reducing the development of rabbit intumal hyperplasia after endothelial denudation. Br J Surg $1989 ; 76: 936 ; 938$.

44. Vashisht, R; Sian, M; Franks, PJ; OMalley, MK: Long-term reduction of intimal hyperplasia by the selective alpha-1 adrenergic antagonist doxazosin. Br J Surg 1992;79:12851288 .

45. Jackson, CL; Bush, RC. Bowyer, DE: Inhibitory effect of calcium antagonists on balloon catheter-induced arterial smooth muscle cell prolfferation and lesion size. Aheroscl 1988;69:115-122. 


\section{SUMMARY}

Restenosis following PTCA is a major clinical problem and seriously limits the efficacy of the procedure. Although SMC proliferation and ECM production are considered characteristics of the restenotic lesion, the regulation of SMC proliferation and ECM production are just beginning to be elucidated. The balloon injury model of the rat carotid artery is a common model to simulate PTCA procedures and study the regulation of SMC proliferation after angioplasty. At least in this rat model, there is now accumulating evidence that AngII is an important regulator of SMC growth. In this thesis the mechanism of Angll induced SMC DNA synthesis is studied, with special attention for the role of $\alpha_{1}$-adrenoreceptors herein. We investigated the effects of AngII infusion and the interaction with the $\alpha_{1}$-adrenoreceptor in non-balloon injured WKY rats (chapters 4,5 and 7) and in balloon-injured WKY rats. In the latter case, the left carotid artery was balloon injured and 14 days later, when a neointima had been formed, drugs were infused. This so called "restimulation model" enables us to dissociate the effects of the drugs on medial and neointimal SMC DNA synthesis.

In our studies we used the thymidine analogue BrdUrd to measure SMC DNA synthesis. Since most studies in the rat balloon injury model use $\left[{ }^{3} \mathrm{H}\right] \mathrm{TdR}$ to label SMC DNA synthesis, we validated the BrdUrd labeling method (chapter 3). Dual labeling by continuous infusion during 4 days with both $\left[{ }^{3} \mathrm{H}\right] \mathrm{TdR}$ and BrdUrd immediately after balloon injury of the rat thoracic aorta showed that more than $80 \%$ of all labeled cells were labeled with both [ $\left.{ }^{3} \mathrm{H}\right] \mathrm{TdR}$ and BrdUrd, suggesting that BrdUrd labeling is a good alternative for $\left[{ }^{3} \mathrm{H}\right] \mathrm{TdR}$ labeling.

Continuous AngII infusion during 14 days induces SMC DNA synthesis in the media of the thoracic aorta (chapter 4). The $\alpha_{1}$-adrenoreceptor is involved in the induction of medial SMC DNA synthesis by AngII and this effect seems to be blood pressure independent, since coinfusion with the $\alpha_{1}$-adrenoreceptor antagonist prazosin reduces the Angll induced increase in SMC DNA synthesis, while the systolic blood pressure remains elevated. Angll also induces SMC DNA synthesis in main branches of the aorta (chapter 5). We investigated the carotid, the renal, the femoral artery and the superior mesenteric artery. Intervascular heterogeneity was observed in the amount of SMC DNA synthesis induced by AngII. The renal artery was the most sensitive to stimulation with Angll. Also in these arteries a role for the $\alpha_{1}$-adrenoreceptor is implicated since coinfusion with prazosin reduced SMC DNA synthesis in all but one artery, the superior mesenteric artery.

In the balloon injured rat carotid artery Angll infusion induces a significant rise in SMC DNA synthesis in both media and neointima (chapter 6). The effect is much more pronounced in the neointima than in the media, implicating intravascular heterogeneity in growth response. To investigate the possible involvement of the $\alpha_{1}$-adrenoreceptor in neointimal SMC DNA synthesis induced by AngII, another 
$\alpha_{1}$-adrenoreceptor antagonist doxazosin was coinfused with Angll. In the noninjured right carotid media, doxazosin reduced the Angll induced SMC DNA synthesis, supporting our previous findings (chapter 4 and 5) and showing that this effect is class specific and not substance specific. However, $\alpha_{1}$-adrenoreceptor blockade with doxazosin did not reduce the AngIl induced SMC DNA synthesis in the neointima.

To investigate whether stimulation of the $\alpha_{1}$-adrenoreceptor alone could stimulate SMC DNA synthesis in the media of the thoracic aorta and its main branches (carotid, renal, femoral and superior mesenteric artery) we infused the $\alpha_{i}$-adrenoreceptor agonist phenylephrine and compared it with the effects of Angll infusion (chapter 7). We used young, 6 week old WKY rats, since significant differences in SMC DNA synthesis in the media of large arteries were demonstrated between normotensive WKY rats and spontaneously hypertensive rats at this age. Phenylephrine induced an increase in SMC DNA synthesis in the media of the thoracic aorta, but had no effects in other arteries investigated. Angll infusion did not increase SMC DNA synthesis in these arteries. Stimulation of the $\alpha_{1}$-adrenoreceptor with phenylephrine in adult WKY rats of which the left carotid artery was previously balloon injured, did only increase SMC DNA synthesis in the non-injured right carotid media. No increase in SMC DNA synthesis was found in the media or neointima of the injured left carotid artery (chapter 8). The data in chapters 6-8 suggest that the $\alpha_{1}$-adrenoreceptor is involved in the regulation of SMC DNA synthesis in the non-injured media, but not in the medial and neointimal SMC after balloon injury of the left carotid artery. Since phenylephrine infusion has been suggested to stimulate the release of NO, the lack of effect of phenylephrine on SMC DNA synthesis might be due to antiproliferative effects of NO. NO synthesis inhibition with $\mathrm{N}^{\mathrm{B}}$-nitro $\mathrm{L}$-arginine methylester (L-NAME) did however not increase the SMC DNA synthesis by phenylephrine, suggesting that $\mathrm{NO}$ is not involved in the phenylephrine induced SMC DNA synthesis.

In order to extend our view to other vessel "compartments" that might play a role in structure, we also studied the effects of Angll infusion on the extracellular matrix components elastin and collagen, that compromise a large part of the vessel volume (chapter 9). AngIl infusion increased the synthesis of both elastin and collagen type $I$ and III mRNA but only in the carotid neointima, whereas no effects of Angll were found in the media. Angll infusion did not change the relative amounts of elastin and collagen protein. An increase in the absolute collagen protein amount was demonstrated in the carotid neointima, but only by morphometric analysis. The data suggest that the effects of Angll on the extracellular matrix components elastin and collagen have a different time span than the effects of Angll on vascular SMC DNA synthesis, and that the effects of Angll may be different between media and neointima. 
Altogether, the results in this thesis show that Angli stimulates SMC DNA synthesis and indicate that one pathway involves the $\alpha_{1}$-adrenoreceptor. The involvement of the $\alpha_{1}$-adrenoreceptor in the regulation of AnglI induced SMC DNA synthesis are, however, heterogeneous not only within the vessel (media vs. neointima, SMC vs. extracellular matrix), but also in between vessels (different arteries, e.g. the thoracic aorta and its main branches), and in time (young vs. adult rats). 


\section{SAMENVATTING}

Restenose na percutane transluminale coronaire angioplastie (PTCA, ook wel ballondilatatie of "dotteren" genoemd) vormt een groot klinisch probleem en beperkt in ernstige mate de efficientie van de behandeling. Hoewel verondersteld wordt dat proliferatie van gladde spiercellen en produktie van extracellulaire matrix $(\mathbb{E C M})$ belangrijke kenmerken zijn van de restenotische lesie, zijn de regulatiemechanismen nog niet opgehelderd. Een veel gebruikt diermodel om het restenose proces te simuleren en de regulatie van de proliferatie van gladde spiercellen te bestuderen is het ballondenudatie model in de arteria carotis communis (halsslagader) van de rat. Uit andere studies is gebleken dat in dit experimentele rattemodel het eiwit angiotensine II (AngII) een belangrijke regulerende stof vormt in de groei van gladde spiercellen. In dit proefschrift wordt het mechanisme onderzocht waarop AngII de proliferatie van gladde spiercellen stimuleert met speciale aandacht voor de rol van de $\alpha_{1}$-adrenoreceptoren in dit proces. We hebben de effecten van Angll infusie en de rol van de $\alpha_{1}$-adrenoreceptor bestudeerd in de vaatwand van niet-ballongedenudeerde Wistar Kyoto (WKY) ratten (hoofdstukken 4,5 en 7) en in ballongedenudeerde WKY ratten (hoofdstukken 6 en 8). Bij de laatste groep werd de linker a. carotis van de rat ballongedilateerd en 14 dagen later, wanneer een nieuwgevormde gladde spierlaag, de zgn. "neointima" zich had gevormd, werden farmaca toegediend. Dit zgn. "restimulatie model" maakt het ons mogelijk om onderscheid te maken tussen de effecten wan de farmaca op de DNA synthese in de mediale en neointimale gladde spiercel.

In de experimenten gebruikten we de thymidine analoog $5^{\prime}$-bromo-2'-deoxyuridine (BrdUrd) om de DNA synthese in de gladde spiercel te meten. In het algemeen wordt echter gebruik gemaakt van radioaktief gelabeled tritium thymidine ( $\left.\left.{ }^{3} \mathrm{H}\right] \mathrm{TdR}\right)$ om de DNA synthese in de gladde spiercel te bepalen en daarom hebben we de betrouwbaarheid van de BrdUrd labelings methode onderzocht (hoofdstuk 3). Gelijktijdige toediening van beide labels, BrdUrd en [ $\left.{ }^{3} \mathrm{H}\right] T$ dR, door continue infusie gedurende 4 dagen direct na ballondilatatie van de thoracale aorta van de rat toonde aan dat meer dan $80 \%$ van alle gelabelde cellen met zowel [ H]TdR als BrdUrd gelabeld waren. Dit suggereert dat de BrdUrd labeling methode een goed alternatief vormt voor de radioactieve methode, die veel tijd kost en duur is.

Continue infusie met AngIl gedurende 14 dagen stimuleert de DNA synthese in de gladde spiercel in de media van de thoracale aorta (hoofdstuk 4). De $\alpha_{1}$ adrenoreceptor is betrokken bij de inductie van de DNA synthese in de mediale gladde spiercel en dit effect lijkt onafhankelijk te zijn van de bloeddruk, aangezien coïnfusie met de $\alpha_{1}$-adrenoreceptor antagonist prazosine de Angll geinduceerde DNA synthese in de gladde spiercel reduceert, terwijl de bloeddruk verhoogd blijft. Behalve in de media van de thoracale aorta, induceert AngII ook. DNA synthese in de gladde spiercel in de hoofdtakken van de aorta (hoofstuk 5). Wij bestudeerden 
de arteria carotis, a. renalis (nierarterie), a. femoralis (dijbeenarterie) en de a. superior mesenterica (darmarterie). De mate van DNA synthese in de gladde spiercel verschilde per arterie, hetgeen duidt op intervasculaire heterogeniteit. De a. renalis was het meest gevoelig voor stimulatie met Angll. In de bestudeerde arteriën bleek ook de $\alpha_{1}$-adremoreceptor cen rol te spelen, aangezien de coinfusie met prazosine de DNA synthese in de gladde spiercel in alle vaten reduceerde, behalve in de a. superior mesenterica.

In de ballongedilateerde a. carotis induceerde Angll een significante toename in DNA synthese in de gladde spiercel in zowel de media als in de neointima (hoofdstuk 6). Het effect op de neointima was veel groter dan op de media, hetgeen duidt op een intravasculaire heterogeniteit in de groeirespons. Om de mogelijke betrokkenheid van de $\alpha_{1}$-adrenoreceptor in de neointimale DNA synthese in de gladde spiercel te onderzoeken werd een andere $\alpha_{1}$-adrenoreceptor antagonist doxazosine (i.p.v. prazosine) tesamen met AngII toegediend. In de niet beschadigde rechter a. carotis, reduceerde doxazosine de DNA synthese in de gladde spiercel in de media, hetgeen onze voorgaande bevindingen uit hoofdstuk 4 en 5 bevestigt. De $\alpha_{1}$-adrenoreceptor blokkade met doxazosine reduceerde echter niet de door AnglI geinduceerde DNA synthese in de gladde spiercel in de neointima.

Om te onderzoeken of directe stimulatie van de $\alpha_{1}$-adrenoreceptor de DNA synthese in de gladde spiercel kan induceren in de media van de thoracale aorta en zijn hoofdtakken (a. carotis, a. renalis, a. femoralis en a. mesenterica superior) werd de $\alpha_{1}$-adrenoreceptor agonist fenylephrine toegediend (continu infuus) en vergeleken met de effecten van AngII (hoofdstuk 7). Voor deze studie werden 6 weken oude WKY ratten gebruikt, aangezien significante verschillen in de DNA synthese in de gladde spiercel zijn aangetoond tussen WKY ratten en spontaan hypertensieve ratten op deze leeftijd. Fenylephrine induceerde een significante toename in de DNA synthese in de gladde spiercel in de media van de thoracale aorta, mar had geen effect op de DNA synthese in de andere bestudeerde arteriën. Stimulatic van de $\alpha_{1}$-adrenoreceptor met fenylephrine in volwassen WKY ratten waarvan de linker a. carotis 14 dagen tevoren was ballongedilateerd, had alleen effect op de DNA synthese in de mediale gladde spiercel in de onbeschadigde rechter a. carotis. Fenylephrine induceerde geen DNA synthese in de gladde spiercel in de media of neointima van de beschadigde linker a. carotis (hoofdstuk 8). De resultaten van hoofdstuk 6-8 suggereren dat de $\alpha_{1}$-adrenoreceptor betrokken is bij de regulatie van de DNA synthese in de gladde spiercel in de onbeschadigde media, maar niet in de mediale en neointimale gladde spiercel na ballondilatatie van de linker a carotis. Aangezien verondersteld wordt dat fenylefrine de afgifte van stikstofoxide (NO) kan stimuleren, zou het onvermogen van fenylephrine om de DNA synthese in de gladde spiercel te kunnen stimuleren, misschien te wijten zijn aan de proliferatie-remmende eigenschappen van NO. NO synthase inhibitie met de $N^{3}$-nitro L-arginine methylester (L-NAME) stimuleerde de DNA synthese 
in de gladde spiercel met fenylephrine echter niet, zodat NO waarschijnlijk niet betrokken is bij de DNA synthese onder invloed van fenylephrine.

De effecten van Angll op de extracellulaire matrix componenten elastine en collageen, die een belangrijk deel van het vaatwand volume in beslag nemen en van belang zijn voor de vaatwandstructuur, zijn in hoofdstuk 9 bestudeerd. Angll infusie stimuleerde de synthese van elastine en collageen type II en type III mRNA in de neointima, terwijl geen effecten van Angll werden gevonden in de media. AngII infusie veranderde de relatieve hoeveelheid elastine en collageen eiwit nict. Uit morphometrische analyse bleek een toename in de absolute hoeveelleid collageen eiwit in de neointima. De resultaten suggereren dat de effecten van AngII op de extracellulaire matrix componenten elastine en collageen op een ander tijdsstip optreden dan de effecten van AngIl op de DNA synthese in de gladde spiercel, en dat de effecten verschillen tussen de media en de neointima.

Samenvattend geven de resultaten in dit proefschrift aan dat Angll de DNA synthese in de gladde spiercel stimuleert en dat de $\alpha_{1}$-adrenoreceptor hierbij betrokken is. De betrokkenheid van de $\alpha_{1}$-adrenoreceptor in de regulatie van de door AngII geinduceerde DNA synthese in de gladde spiercel is echter heterogeen, niet alleen in de vaatwand (media vs. neointima, gladde spiercel vs. extracellulaire matrix), maar ook tussen verschillende vaten (de thoracale aorta vs. zijn hoofdtakken), en in de tijd (jonge vs. volwassen ratten). 


\title{
CURRICULUM VITAE
}

\author{
Ellen M. van Kleef
}

23 september 1965

$1977-1983$

1983-1989

$1989-1993$

mei-juli $\llbracket 991$

september 1993
Geboren te Rotterdam

VWO, Thomas a Kempis College te Arnhem

Studie Biologie aan de Landbouw Universiteit te Wageningen

Afstudeervakken: ethologie, toxicologie en celbiologie

Aanstelling als assistent in opleiding bij de vakgroep Pathologie, Cardiovascular Research Institute Maastricht, Faculteit der Geneeskunde, Rijksuniversiteit Limburg

Stage bij C.N. Wilcox, Division of Hematology and Oncology, Faculty of Medicine, Emory University School of Medicine, Atlanta, GA, U.S.A.

Aanstelling alls toegevoegd onderzoeker bij dezelfde vakgroep

\section{LIST OF PUBLICATIONS}

\section{Full papers}

Zwijsen, RML; van Kleef, EM; Alink, GM: A comparative study on the metabolic activation of 3.4-benzo(a)pyrene to mutagens by aorta snooth muscle cells of rat and rabbit. Mutation Research 1990;230:111-117.

van Kleef, EM; Smits, JFM; De Mey, JGR; Cleatjens, JPM; Lombardi, DM; Schwartz, SM;

Daemen, MJAP: Alpha L-adrenoreceptor blockade reduces the angiotensin II induced vascular smooth muscle cell DNA synthesis in the rat thoracic aorta and carotid artery. Cinc Res 1992;70:1122-1127.

Boonen, HCM; Daemen, MJAP; Eerdmans, PA; fazzi, GE; Janssen, GMJ; van Kleef, EM;

Schiffers, PMH; De Mey, JGR: Mesenteric resistance artery changes following vasoconstrictor infusion in young rats. I Cardiov Pharmacol 1993;22:388-395 
van Kleef, EM; Smits, JEM; Sehwartz, SM; Daemen. MJAP: Efects of $\alpha_{1}$-adrenoreceptor blockade with doxazosin on the angiotensin I1-induced smooth muscle DNA synthesis in the balloon infured rat carotid artery. Current Advances in ACE infribition 3 (dS. Mc Gregor, GA: Sever, P.S). In press.

van Kleef, EM; Lombardi, DM; Schwarz, SM; Daemen, MJAP: Comparison of the detemination of DNA synthesis by [H]thymidine and 5-bromo-2"-deoxyuridine in the balloon injured rat thoracic aorta. Submitted.

van Kleef, EM; Smits, JFM; Schwart, SM; Daemen, MJAP: Heterogeneous effects of $\alpha_{1}$-adrenoreceptor blockade with doxazosin on the angiotensin il induced smooth muscle cell DNA synthesis in the balloon injured rat carotid artery. Submitted.

van Kleef, EM; Fazzi, GE; Janssen, G; Janssen, AJMH; Schiffers PM; MAP Daemen, De Mey, JGR: Heterogeneity of growth responses in the arterial system of young rats during infusion with phenylephrine and angiotensin II. Submitted.

\section{Abstracts}

warn Kleef, EM; Smits, JFM; Essen, H van; Schwart, SM; Bosman, FT; Daemen, MJAP; Prazosin blocks the vascular smooth muscle cell DNA synthesis induced by angiotensin II. Acta Clinica Belgica 1991;46:254.

wan Kleef, EM; Smits, JFM; Essen, H van; Schwartz, SM; Bosman, FT; Daemen, MJAP: Prazosin blocks the vascular smooth muscle cell DNA synthesis induced by angiotensin II. Dutch Federation Meeting, Amsterdam, the Netherlands, 1991.

van Kleef, EM; Smits, JEM; Essen, H van; Schwartz, SM; Bosman, FT; Daemen, MJAP: Smooth muscle cell DNA synthesis induced by angiotensin II is blocked by prazosin. Federal Proceedings $5, A 82,1991$.

van Kleef, EM; Smits, JFM; De Mey, JGR; Cleutjens, JPM; Lonbardi, DM; Schwartz, SM; Daemen, MJAP: Alfa-1 adrenerge blokkade door prazosine verlaagt de angiotensine II geïnduceerde gladde spiercel DNA syrthese in de arteria carotis van de rat. Ned Tijdsclur Geneeskd 1992; 136, nr.34:1682.

van Kleef, EM; Smits, JFM; De Mey, JGR; Cleutjens, JPM; Lombardi, DM; Schwartz, SM; Daemen, MJAP: Prazosin reduces the angiotensin II induced vascular smooth muscle cell DNA synthesis in the rat. Advances in atherosclerotic heart disease, European Society of Cardiology, Tubingen, Germany, 1992.

varn Kleef, EM; Smits, JFM; De Mey, JGR; Cleutjens, JPM; Lombardi, DM; Schwartz, SM; Daemen, MJAP: $\alpha-1$-Adrenoceptor blockade by prazosin reduces the angiotensin II induced smooth muscle cell DNA synthesis in the rat artery. European Vascular Association. $13^{\text {th }}$ European Conference on Vascular Biology, Venice, Italy, 1992.

van Kleef, EM; Smits, JFM; Schwartz, SM; Daemen, MJAP: Effects of $\alpha_{1}$-adrenoceptor blockade with doxazosin on the angiotensin II induced smooth muscle cell DNA synthesis in the balloon injured rat carotid artery. Third Intemational Symposium on ACE inhibition, Amsterdam, the Netherlands, 1993.

van Kleef, EM; Smits, JFM; Schwarti, SM; Daemen, MJAP: Effects of $\alpha_{1}$-adrenoceptor blockade with doxazosin on the angiotersin II induced smooth muscle cell DNA synthesis in the balloon injured rat carotid artery. Dutch Hypertension Society, Utrecth, the Netherlands, 1993. 



\section{DANKWOORD}

Aan het einde gekomen van dit proefschrift wil ik graag iedereen bedanken die heeft meegeholpen aan de totstandkoming ervan.

Zowel de medewerkers van de vakgroep pathologie, als ook velen van de vakgroep farmakologie hebben in de afgelopen vier jaar gezorgd voor een plezierige werksfeer. Met enkele mensen heb ik nauw samengewerkt en hen wil ik daarom in het bijzonder bedanken.

Mijn begeleider, Mat Daemen, ook bekend als "de baas" of "boss" van de cardiovasculaire onderzoeksgroep. Ik heb jouw positieve inzet en snelheid van werken altijd bewonderd. Met name in het laatste jaar was het heel fijn dat jij mijn schrijtwerk steeds snel corrigeerde en direkt met me doorsprak. Dit werkte voor mij zeer motiverend. Ook heb ik het bijzonder gewaardeerd dat jij het contact met $\mathrm{Cy}$ Wilcox aanhaalde, zodat ik een waardevolle stage kon doen.

Mijn promotor, Jan-Wiliem Arends bedank ik voor zijn interesse en kritische beschouwing van mijn schrijfvorderingen tijdens het afgelopen jaar.

Verder wil ik Jo De Mey, tevens lid van de beoordelingscommissie, en Jos Smits van de vakgroep farmakologie bedanken. Als participanten van de experimenten beschreven in dit proefschrift hebben zij voor de nodige farmakologische ondersteuning gezorgd, zowel in het bepalen van de dosis-effect relaties van de farmaca, alswel in het "aan de praat krijgen van bloeddrukmeters" en kritische discussies.

Steve Schwartz, I would like to thank you for reading the manuscript and reviewing several papers. I hope to continue the collaboration with you in the near future.

Ook de andere leden van de beoordelingscommissie, Prof. dr. P.W. de Leeuw, Prof. dr. P.D. Verdouw en Dr. F.W.H.M. Bär wil ik bedanken voor hun kritische beoordeling van het manuscript.

Cy Wilcox, I would like to thank you for teaching me "how to become an in situ expert", it has been a pleasure to work in your lab.

Verder wil ik de analisten bedanken die een groot atandeel hebben gehad in het praktische werk. Caroline Eerdmans en Helma van Essen bedank ik voor de energie en het geduld die zij hebben gestoken in het meten van bloeddrukken en tevens dank ik Caroline voor de vele ballondenudaties. Anique Janssen bedank ik voor de 
bijzonder prettige samenwerking met name in het laatste jaar. Terwijl ik zat te schrijven deed jij vele in situ hydridisaties, BrdU kleuringen en morfometrie.

Ook Petra Aarts leverde heel wat kant-en-klare BrdU's en CSA metingen aan, en verder leerde Monique Verluyten mij de eerste beginselen van de moleculaire biologie. Cor Beek bedank ik voor de de biochemische bepalingen en computer "know how".

Tenslotte hebben mijn vader en Riet een nimmer aflatende interesse gehad voor mijn bezigheden. Mijn vader dank ik voor zijn altijd zo goede zorgen tijdens middelbare schoolperiode en studie, en Riet voor haar positieve kijk op mijn werk en het maken van het "promoveertenue".

En Wessel, bedankt voor de gezellige weekenden tijdens deze stressvolle laatste loodjes. 